Universidade de São Paulo

Escola de Comunicações e Artes

Departamento de Artes Cênicas

\title{
O ator na cena contemporânea: \\ corpo, imagem e ação
}

\section{AURA CUNHA SANTOS}

São Paulo

2010 
Universidade de São Paulo

Escola de Comunicações e Artes

Departamento de Artes Cênicas

\section{O ator na cena contemporânea: corpo, imagem e ação}

\section{AURA CUNHA SANTOS}

Dissertação de mestrado apresentada ao Programa de Pós-Graduação da Escola de Comunicação e Artes da Universidade de São Paulo, como um dos requisitos para a obtenção do título de Mestre em Artes Cênicas.

Orientadora: Elisabeth Silva Lopes.

São Paulo

2010 


\section{FOLHA DE APROVAÇÃO}

Aura Cunha Santos

O Ator na cena Contemporânea: corpo, imagem e ação.

Dissertação de mestrado apresentada ao Programa de Pós-Graduação da Escola de Comunicação e Artes da Universidade de São Paulo, como um dos requisitos para a obtenção do título de Mestre em Artes Cênicas.

Orientadora: Elisabeth Silva Lopes.

Aprovado em:

\section{Banca examinadora}

Prof(a). Dr(a).

Intituição:

Assinatura

Prof(a). Dr(a).

Intituição: Assinatura

Prof(a). Dr(a).

Intituição: Assinatura 
À Memória

Às Cunha 


\section{AGRADECIMENTOS}

À Elisabeth Silva Lopes, por toda generosidade, franqueza e paciência com que soube compartilhar o seu conhecimento, nesta parceria que tanto me fez crescer. À Silvia Fernandes e Luiz Fernando Ramos, que sempre responderam prontamente às minhas demandas intelectuais e afetivas e ao Renato Ferracini, por seu olhar incisivo. Ao Vina, que com todo seu jeito manco de ser, me fez ver o que eu não via e me colocou de pé. Ao amigo, que com todos os quadrados permitiu-me ver redondo. À Bianca, minha companheira, que em meus momentos de desespero e paralisação me sugeria, pacientemente, elaborar a lista de referências bibliográficas. Ao cabeça e nossas conversas a metro. À família Cunha, que sempre acreditou em mim, que me faz seguir adiante e me possibilita ser o que eu sou. Em especial à minha mãe, que dá chama à vida e à minha sobrinha Zoé, que traz chama nova à vida. À Margô pela generosa revisão. E, em destaque, à Companhia de Teatro em Quadrinhos, nas figuras de Beth Lopes, Maria Helena Chira, Leonardo Moreira e Eduardo Mossri, que me possibilitaram viver mundos imaginários.

Esta pesquisa foi realizada com o financiamento da Fundação de Amparo à Pesquisa do Estado de São Paulo (FAPESP) 


\section{RESUMO}

O presente estudo visa analisar e refletir a respeito do ator na prática teatral contemporânea, a partir de seus aspectos materiais tratados como imagem e ação e enfatizados pelo corpo. A atenção se volta a uma cena que se opõe aos paradigmas de um teatro representativo e se concentra em determinada teatralidade material. Para tanto, aborda as noções de teatralidade e performatividade e a tensão entre o real e o ficcional, a fim de retirar premissas que possivelmente orientam uma atuação convergente a tais propostas. Assim, propõe-se a refletir sobre procedimentos e resultados que acompanham as proposições estéticas e de linguagem da Cia. de Teatro em Quadrinhos, que tem como base a constituição de uma materialidade que se cria a partir da cena e enfatiza o aspecto corporal do ator. Trata, portanto, do corpo e da presença do ator em ação como vetores que se operam nesta cena, observando seu aspecto material e expressivo de modo a produzir imagens que buscam uma comunicação direta com o público sem a intermediação de um corpo fictício. Com isso, leva-se em consideração uma atitude performática por parte do ator, que atua como cocriador/colaborador do espetáculo cênico e se caracteriza em cena como ser vivo, atuante e real. Nesse circuito ele permanece entre "linguagem e vida", entre a possibilidade de ser e a certeza de ser, entre a representação do outro e a representação de si, expondo seu corpo e sua ação como realidade inscrita e presentificada no tempo e no espaço.

Palavras-chave: Ator e cena contemporânea. Teatralidade. Performatividade. Corporeidade. Imagem. Ação. 


\section{ABSTRACT}

This study aims to analyze and reflect on the actor in contemporary theatrical practice, from material aspects that are treated as image and action and that are emphasized through the body. The attention turns to a scene that opposes the paradigm of a representative theater and focuses on certain material theatricality. For that, this study explores the notions of theatricality and performativity and the tension between the real and the fictional, to remove certain assumptions that guide a performance possibly converging to these proposals. From this, it is proposed to reflect on procedures and results that accompany the proposals and aesthetic language of Cia. de Teatro em Quadrinhos, which is based on the formation of a materiality that is created from the scene and that emphasizes the aspect of actor embodiment. Therefore, this research talks about body and presence of the actor in action, as principles that operate in this scene, considering its appearance and expressive material to produce images that aim to direct communication with the public without the intermediation of a fictitious body. With that, it takes into consideration certain performative attitude on the part of the actor, who acts as cocreator / collaborator of the scene and that is characterized as alive, active and real being. And in this circuit it stays between "language and life", between the possibility of being and the confident of being, between representation of other and the representation of themselves, exposing their bodies and their action as reality entered and made present in time and space. 


\section{SUMÁRIO}

INTRODUÇÃO

PARTE I - UMA CENA CONTEMPORÂNEA .............................................................14

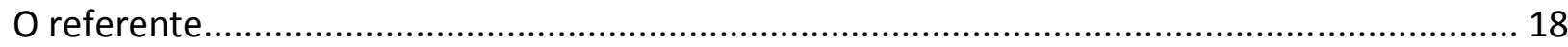

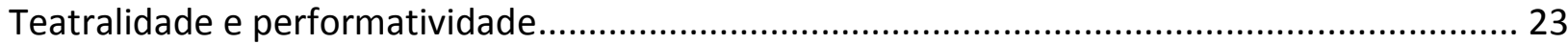

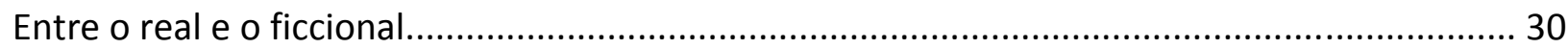

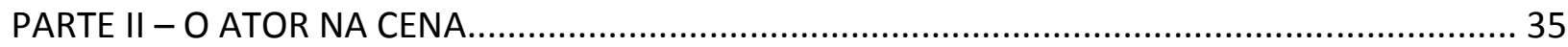

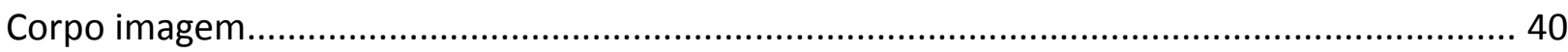

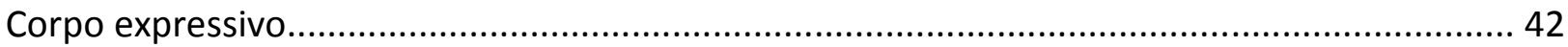

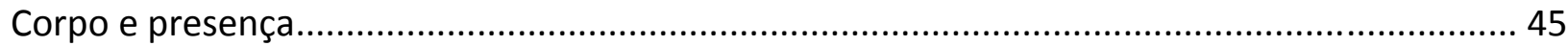

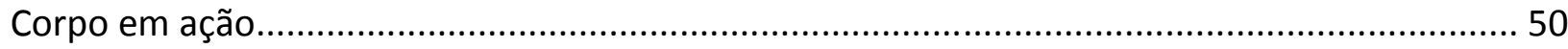

PARTE III - CIA E CENA: Cia. de Teatro em Quadrinhos........................................................ 57

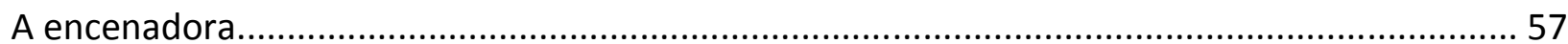

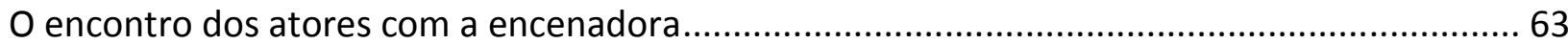

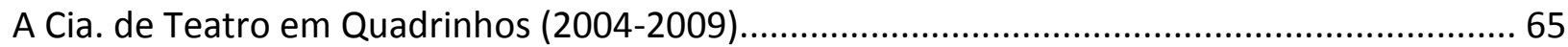

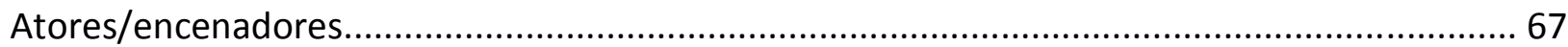

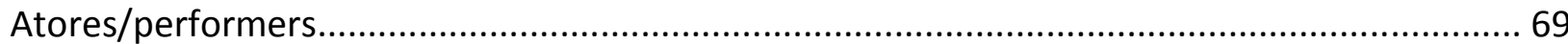

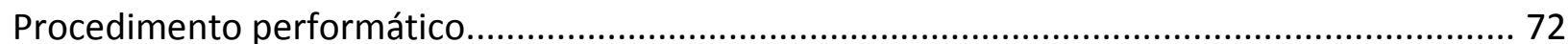

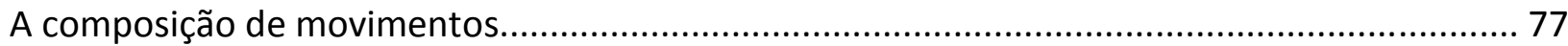

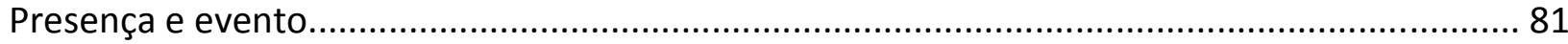

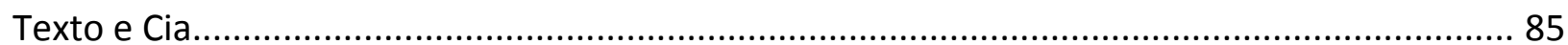

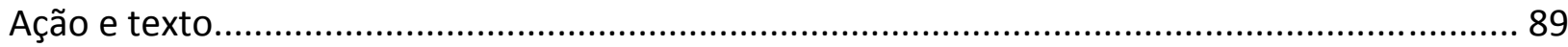

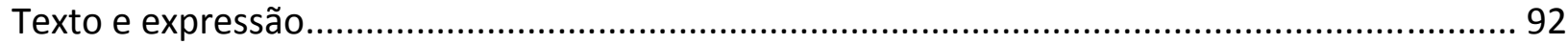

CONCLUSÃO: em cinco cliques de salsicha a Platão!.......................................................... 94

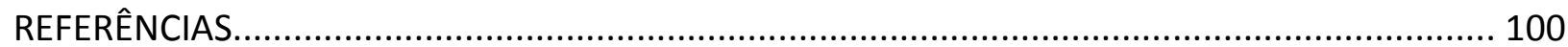




\section{INTRODUÇÃO}

Como traduzir em palavras o que pertence ao fazer?

Diante da diversidade de formas, linguagens e procedimentos presenciados nas práticas teatrais atuais, e mais ainda, diante do uso incontestável de diversas linguagens artísticas para a realização e composição de uma obra teatral, depara-se com a impossibilidade de definir com precisão as bases constituintes da linguagem teatral que se operam na contemporaneidade. Do mesmo modo, falar da cena contemporânea sob os rótulos de um novo teatro, de uma cena alternativa ou mesmo de um teatro de vanguarda, não nos parece suficiente para circunscrever uma prática tão vasta e volátil. Isto porque não há mais cartilhas ou programas estéticos que definiram a efetiva realização de uma obra artística, segundo tal ou tal princípio que lhe conferisse um selo de legitimidade.

Neste estudo, partimos de conceitos que nos permitissem navegar com maior ou menor precisão sobre a instabilidade da criação teatral contemporânea, levando em consideração espetáculos e os processos criativos que os precedem. Dito de outro modo, apresenta-se um painel sobre correntes teóricas que exploram o campo do teatro contemporâneo para refletir sobre procedimentos e resultados que acompanham as proposições estéticas e de linguagem da Cia. de Teatro em Quadrinhos. A companhia fundamenta-se na constituição de uma de materialidade que se cria a partir da cena e enfatiza o aspecto corporal do ator, sempre em uma perspectiva autoral. Neste sentido, acreditamos ser possível fazer teoria à medida que a própria obra (procedimentos e resultados formais) oferece um universo referencial e potencial de onde podemos recolher algumas noções que dela emergem, entrelaçando-as com conceitos e teorias presentes nos debates atuais.

Optamos, assim, por fazer um recorte sobre o painel da cena contemporânea, segundo as teorias de Josette Féral $(1985,2001)$ e mais especificamente sobre seus estudos acerca da teatralidade e de sua concepção de Teatro Performativo (2007). Seguimos, ainda, os passos de H-T. Lehmann (2007) e sua concepção de teatro pós-dramático. Nesta abordagem, deu-se real 
atenção a uma cena que se opõe aos paradigmas de um teatro representativo e se concentra em certa teatralidade material, enfatizando um teatro que se afasta do uso do texto como referente para as criações cênicas.

Para tanto, foi necessário apresentar a abordagem que cada um desses autores faz em relação à linguagem e convenção cênica, à organização dos elementos teatrais e, consequentemente, às mudanças que acompanharam o fenômeno teatral nas últimas décadas. Em visão abrangente, persebe-se a teatralidade e a performance como princípios que se operam na cena contemporânea, segundo Féaral. De outro ângulo, tem-se a perspectiva de um teatro que avança em relação ao drama e sua consequente ruptura com o texto teatral, segundo Lehmann. Neste sentido, tratamos da questão do referente, afastando as produções teatrais de um cosmos preexistente definido por uma voz externa que passa a concentrar seus esforços em fundar-se como realidade existente e independente. No entanto, leva-se em consideração a noção de representação e os processos dinâmicos de constituição de ficcionalidade que parecem acompanhar o fenômeno da teatralidade, tensionando-a ao conceito de performatividade, derivada da arte da performance, e o impacto que causou na tradição teatral, abrindo espaço para novas configurações cênicas e marcando definitivamente a ruptura do teatro com o texto.

Tomamos a teatralidade como um fenômeno que nos direciona aos processos imaginários, de produção de sentidos e nos liga à representação, ao passo que a performatividade nos remete à percepção real do fenômeno teatral. Tal posicionamento nos levou à tensão que se produz na conjugação dos aspectos reais e ficcionais que encerram o fenômeno teatral. Aborda-se este enfoque sob o ponto de vista de uma cena que convida o espectador a deter-se diante de seus aspectos sensíveis, observando-a e experimentando-a enquanto realidade material. Mas também, sobre a presença do ator em cena, que encerra em si o paradoxo de pertencer à ordem do real e à ordem da representação. Deste modo, a presença do corpo em cena, que abrange o nível corporal, perceptivo e mental do sujeito, revelou-se como potente campo para tratar questões que envolvem os conflitos que se operam na cena atual. 
Vale destacar que, este trabalho levou em consideração a relação coletiva que se estabelece no ato teatral e os pactos acordados entre atores e público, e com isso, a participação ativa do espectador em relação à obra. Neste sentido, os estudos propostos por Érika Fischer-Lichte (2007) nos encaminharam para a sugestiva instabilidade que se processa na cena contemporânea, à medida que explora, cada vez mais, uma percepção pendular, na qual o sujeito permanece em um constante vai e vem entre a ordem da presença e a ordem da representação. Isto porque, quando estamos diante de um ser ou objeto real, não permanecemos somente diante de sua presença, experimentando as sensações que desencadeia em nossa sensibilidade. Os procedimentos mentais que se operam a partir deste ser ou objeto real seriam processos especulativos que nos atiram para a ordem da representação. Assim, permanecemos em uma dinâmica intermitente, em um estado que transita entre a sensação do objeto e suas reverberações mentais, criando em nossa percepção um movimento transitório entre o real e o ficcional. Deste modo, as noções de teatralidade e performatividade tornaram-se fundamentos teóricos que possibilitaram o exame de diversos aspectos que observamos nas experimentações atuais.

Na segunda parte do estudo, refletiu-se sobre o trabalho do ator no interior das práticas contemporâneas. Desdobrando as noções destacadas no mapa teórico referente à primeira parte, direcionamos a investigação ao teatro que projeta um corpo expressivo e que se utiliza dos princípios da performatividade: um teatro quer escapar dos códigos e oferecer o inapreensível, possível pelo foco que recai sobre a processualidade e a subjetividade, bem como na apreensão da cena como um espaço limítrofe que cria tensão entre o real e o ficcional.

Em convergência às mudanças paradigmáticas apresentadas na configuração desta cena, destaca-se a presença do ator, focando em sua corporeidade enfatizada pelo seu princípio material e real que busca a comunicação direta com o público, sem a intermediação de um corpo fictício. Trata-se do corpo expressivo e da presença do ator em ação como vetores que se operam nesta cena, considerando seus aspectos materiais e expressivos de modo a produzir imagens que não visam uma comunicação codificada, mas que ressaltam uma gestualidade sugestiva, deslocando o foco da imitação para a experiência e o fazer. Com isso, atenta-se para a atitude performática dos atores, o que parece estar em convergência com as 
demandas da cena circunscrita: um sujeito que atua como cocriador/colaborador do espetáculo cênico, que explora seus meios, corpo e ação, e se caracteriza em cena como ser vivo, atuante e real.

Na segunda parte da dissertação introduzimos teóricos e pesquisadores brasileiros que vêm desenvolvendo trabalhos substanciais e teorias de excelência sobre procedimentos e resultados das práticas teatrais. Tais pesquisadores, artistas, teóricos, críticos e professores trazem diálogos potentes que projetam o pensamento mundial nas produções locais, que resultam em ideias coerentes à nossa realidade, produzindo pesquisa e saber referentes às práticas brasileiras. Eles se dispõem a revisar teorias e propor novos pensamentos que podem ser encontrados em periódicos especializados no tema, em cadernos de ensaios, em livros publicados, mas também, em encontros e seminários que vêm ocorrendo cada vez com mais frequência e que contribuem para a circulação e o debate da produção brasileira. Não se faz aqui nenhuma apologia ao solo nacional, mas se reconhece a importância das reflexões que vêm sido debatidas aqui e que contribuem para a participação de nosso pensamento diante das teorias mundiais. Neste sentido, promover uma reflexão sobre a produção da Cia. de Teatro em Quadrinhos, abordada posteriormente, foi uma tentativa de dividir esta prática e o pensamento que ela projeta com outros pesquisadores que se debruçam não só nas práticas mundiais, mas também na realidade brasileira.

Na terceira parte da pesquisa, cruzamos alguns princípios apreciados na primeira e na segunda partes com os procedimentos criativos de alguns dos espetáculos da Cia. de Teatro em Quadrinhos, realizados nos últimos cinco anos - período em que se manteve um núcleo estável de criadores. Este grupo, formado por ex-alunos do Departamento de Artes Cênicas da USP e dirigido por professora do mesmo departamento, serviu de campo de estudo para uma avaliação sobre resultados que determinadas práticas projetam. Permitimo-nos, assim, entrar no universo da Cia. de Teatro em Quadrinhos para explorar seus processos criativos, suas intenções, destacar seus objetivos, independentemente de seu resultado final e sem a intenção de definir suas proposições artísticas. Ao contrário, procuramos encontrar possíveis reverberações desta prática, abordando conceitos que se processam na cena teatral contemporânea. Com base nas reflexões teóricas, pudemos oferecer o cruzamento entre 
teorias e práticas que conduzem as proposições estéticas desta companhia. Do mesmo modo que nos parece impossível definir um programa, determinar uma nomenclatura, esclarecer as diretrizes da cena contemporânea, não nos propusemos a determinar uma linguagem essencial que orientaria a criação deste grupo, pois nossa análise não pretendeu espelhar os conceitos teóricos sobre a prática da Cia. Tal operação poderia se tornar artificiosa, a ponto de correr-se o risco de esquematizar a invenção, ou mesmo, limitar a criação artística, e não considerar o modo caótico e multifacetado com que ela se organiza. E, como acreditamos que não há uma fórmula para alcançar um resultado, tampouco um sistema metodológico que objetive sua realização, pensar sobre esta prática foi dividir com outros pesquisadores possíveis reflexões que dela surgem. Isto porque percebemos a teoria do teatro não como um programa o qual encenadores, atores, professores e alunos devam procurar atingir. Mas sim uma análise sobre as práticas existentes: a teoria seria, na melhor das hipóteses, uma reflexão sobre a prática do teatro. Portanto, sentimo-nos confortáveis em ponderar sobre um trabalho prático sem a intenção de legitimá-lo com teatro performativo, teatro pós-dramático, ou qualquer outra nomenclatura, mas para percorrer possíveis raciocínios que possam emergir desta prática.

Foi, portanto, na tentativa de selar o trato entre produção teórica e prática teatral, e não distanciar os resultados cênicos de suas formulações teóricas, que nos debruçamos sobre o processo criativo e a produção de espetáculos. E, mais precisamente, sobre os processos criativos do ator, no esforço de que a consciente reflexão de sua prática e a estreita relação entre teoria e prática é produtiva para sua formação artística. Acreditamos que a prática contínua do teatro, quando inquietante e rigorosa, pode ser tratada como pesquisa e produção de saber. Tratamos, assim, das reflexões teóricas das práticas cênicas que enfatizam o corpo do ator em sua realidade material e expressiva, que pretende uma cena de materialidade instigante. $\mathrm{O}$ ator, neste circuito, permaneceria entre "linguagem e vida", entre a possibilidade de ser e a certeza de ser, entre a representação do outro e a representação de si, expondo seu corpo e sua ação como realidade inscrita e presentificada no tempo e no espaço. 


\section{PARTE I - UMA CENA CONTEMPORÂNEA}

No contexto da prática teatral contemporânea percebe-se mudanças paradigmáticas que consolidaram determinado modo de produção teatral. No que diz respeito ao texto teatral, este modificou o panorama da representação cênica ao explorar outras formas de escrita. 0 que vimos foi o desaparecimento das grandes narrativas e o nascimento de uma dramaturgia de fragmentos; a modificação das formas dos diálogos e a mudança do status da personagem. Em relação à cena teatral, o texto dramático como fonte de produção de cena perdeu sua centralidade, o que intensificou a exploração de diferentes materiais para a criação do espetáculo. Neste espaço, os produtores da cena - encenadores, atores, iluminadores, músicos, dramaturgos e outros profissionais - passam a usar como fonte criativa os próprios materiais que servem de suporte a suas criações. Espaço, corpo, luz, material sonoro, palavras e letras, bem como a colaboração entre os criadores e a contaminação entre suas áreas se transformaram em matéria constituinte do fazer teatral.

As mudanças que se consolidaram ao longo do século XX acarretaram uma diversificação e multiplicidade de procedimentos criativos, tanto quanto uma diversidade de produção que dispensa a categorização do produto. Definir o gênero de um espetáculo, ou mesmo, a linguagem sobre a qual se distingue é matéria de especulação frustrada. Dizer que tal procedimento único foi utilizado para produção de um espetáculo, traçando a escola e os princípios que a regem, ainda que seja possível em muitas produções, é forçar um selo para o produto. O que vemos nas produções contemporâneas é a multivetorização nas elaborações dos espetáculos, isto é, reinventam-se procedimentos a cada início de um novo ciclo e utilizamse as mais diversas fontes para alimentar e ampliar o escopo da criação ${ }^{1}$.

Pode-se dizer que estamos delimitando para esta investigação uma cena que substitui a poética do drama, traçada por Aristóteles e vigente por mais de três séculos, pela poética da cena, esboçada no final do século XIX, que ganhou plena realização no século XX efetivada pela

\footnotetext{
${ }^{1}$ É bem verdade que hoje nas produções paulistas podemos ver certas escolas que orientam as produções, os espaços culturais que as acolhem, os formadores e críticos que as legitimam e as políticas públicas e privadas que as financiam. Mas essas são hipóteses a serem discutidas em outros âmbitos.
} 
figura do encenador. Nesta perspectiva, o teórico, pesquisador e professor do Departamento de Artes Cênicas da USP, Luiz Fernando Ramos, acredita que é possível pensar a tradição moderna como expressão de uma tensão crescente entre a poética do espetáculo e a poética do dramático².

Nesse quadro, acrescentamos toda uma oposição à teatralidade, vista sob o aspecto negativo de falso, dissimulado, enganoso, e a tentativa de resgate do termo como algo essencialmente teatral, ligado à espessura de signos presentes na realização do espetáculo ${ }^{3}$. E ainda, de como a negação à teatralidade aproximou o teatro da realidade, aumentando as tensões entre as esferas do real e do ficcional, na crença de que, ao se afastar do teatro e se aproximar da vida, estaríamos mais próximos da realização de uma obra viva e potente 4 . Para além de todas as reviravoltas ocorridas ao longo de um século, chama-se a atenção, entretanto, para as novas investidas do trabalho do ator em cena, que acarretaram inovadores modos de atuação ${ }^{5}$.

Finalmente, o teatro que nos interessa para esta pesquisa e que tomamos como referência para nossos pensamentos passou a concentrar seus esforços na materialidade da cena, na concretude de seus elementos, e se sustenta na fragmentação do discurso, justaposição, aglutinação, sobreposição e superposição de signos; na colagem, deslizamento e deslocamentos de sentidos.

Hans-Thies Lehmann (2007), professor, pesquisador e teórico alemão, nomeia esta poética atual como teatro pós-dramático. Para construir sua teoria, o autor parte do princípio do dramático ${ }^{6}$, apresentando vasto quadro referencial para analisar as novas formas teatrais e

\footnotetext{
${ }^{2}$ Ramos, Luiz F. “A pedra de toque”. Em Revista Humanidades, edição especial, Brasília: Universidade de Brasília, ${ }^{\circ}$ $52,2006$.

${ }^{3}$ A tentativa de restabelecer a positivação da noção de teatralidade será tratada no item destinado a tal conceito.

${ }^{4}$ Referimo-nos à vida no sentido o qual Artaud preconiza ao final de seu texto "Teatro e Cultura", que prefacia o livro O Teatro e seu duplo: "Quando pronunciamos a palavra vida deve-se entender [...] essa espécie de centro frágil e turbulento que as formas não alcançam." (p. 08) Ou mesmo em seu texto, "Manifesto por um teatro" abortado, no qual Artaud escreve na tentativa de resgatar o valor universal do teatro. "Tudo aquilo que pertence à ilegibilidade, à fascinação magnética dos sonhos, (...) estas camadas sombrias da consciência que são tudo que nos preocupa no espírito, nós queremos vê-las radiar no palco (...)." p. 38

${ }^{5}$ Este aspecto será abordo ao longo de todo o estudo, sendo este nosso principal vetor de investigação.

${ }^{6} \mathrm{O}$ teórico alemão estende as reflexões de Peter Szondi e propõe o pós-dramático, numa perspectiva histórica, como evolução do paradigma dramático.
} 
notificar os deslocamentos que se operaram na atividade teatral, quando da passagem do teatro dramático para o pós-dramático. As mudanças asseguradas nesta passagem dizem respeito a uma poética que não se presta mais à construção de um cosmo fictício, encerrado no palco como realidade autônoma; seu foco, antes, concentra-se nas relações que se estabelecem entre a cena e o público. Decorre daí uma cena que prioriza a comunicação ${ }^{7}$; centra-se na presença e não mais na representação; investe na situação mais do que na ficção; requer a sensualidade dos corpos mais do que a encarnação de personagens; explora o monólogo e o coro, e não mais os diálogos. Isto significa dizer que as categorias dramáticas tradicionais, como ação dramática, personagem, diálogo e ilusão já não são mais suficientes para refletirmos sobre as formas presentes no teatro atual.

Para a pesquisadora, professora e teórica Josette Féral (2008) a cena contemporânea, entretanto, desenvolve-se para além de uma tradição dramática. Segundo ela, o teatro atual perturbou seus gêneros a partir do momento em que adotou certos elementos fundamentais da performance. Contaminado pelas formas e procedimentos próprios desta manifestação artística, as mudanças fundamentais observadas no teatro contemporâneo estariam ligadas às seguintes formulações: o ator que se tornou performer; a ação cênica tratada como evento em detrimento da representação ou jogo de ilusão; o espetáculo centrado na imagem e na ação e não mais sobre o texto ${ }^{8}$. Neste caso, vemos a ênfase dada ao papel do ator, à noção de ação e aos aspectos visuais da cena. Tais características, além de não terem o dramático como referencial e, com isso, a trama como centralidade da obra, solicitam do espectador uma percepção especular, isto é, a cena com suas matérias e imagens, pode ser tomada como superfície refletora para as construções simbólicas do espectador.

Ainda que Lehmann e Féral estejam observando a mesma cena, tratando quase sempre do mesmo sujeito e, por vezes, coincidindo sobre pontos de vista a oposição fundamental que se pode perceber entre os dois autores é o ponto de partida de suas análises. Lehmann

\footnotetext{
${ }^{7}$ No sentido em que todos os envolvidos participam da experiência cênica, mantém-se em contato com aquela realidade, estabelecem relações e se unem para o evento.

${ }^{8}$ Féral, J. Por uma poética performatividade: o teatro performativo. Palestra apresentada no Encontro Mundial das Artes Cênicas (ECUM), São Paulo: 2008, posteriormente publicada na revista Sala Preta, do Departamento de Artes Cênicas da USP, $n^{\circ}$ 8, 2008.
} 
desenvolve sua teoria a partir de um teatro que tem como pré-história o drama e toda a tradição literária, e isto pode ser observado nas categorias que o autor utiliza para caracterizar a cena contemporânea, ou seja, suas noções são sempre colocadas em conflito aos elementos que constituem o teatro dramático, o autor toma como referencial a poética do dramático. Além disto, mantendo a tradição do pensamento marxista, projeta uma finalidade política na acepção estética do fenômeno teatral atual.

As reflexões de Féral, entretanto, surgem de sua observação direta das práticas teatrais - resultados e procedimentos. No contato com os artistas por meio de entrevistas, acompanhando processos criativos e outras circunstâncias, a pesquisadora retira elementos para elaborar seus conceitos operadores. Segundo a professora, sua teoria é uma reflexão que se desdobra de sua observação direta das práticas $^{9}$, e o caminho que utiliza para desenvolver seu pensamento não se define por uma evolução do drama, e sim pelas modificações visíveis nas próprias produções artísticas. Deduz-se com isso que suas teorias acompanham as evoluções da poética da cena e não da poética do drama, observando as evoluções das manifestações cênicas na realização material do evento. Logo, suas reflexões pressupõem toda uma mudança que se deu no interior do teatro, nas experimentações que visavam uma poética da cena como contraposição à mecânica reprodução do texto teatral levada aos palcos - aquela linhagem ligada à negação da teatralidade que procurou expandir suas fronteiras para sair de sua aporia. Além disto, a autora mantém suas análises no campo estético, apesar de não negar o que de político continham tais movimentos, ao contextualizar o momento histórico no qual surgiram, além de não prospectar uma finalidade política destas práticas em suas reflexões.

Seja teatro pós-dramático, seja mesmo teatro performativo, ambos oferecem, ao contexto cênico atual, operadores potentes que auxiliam as reflexões sobre as mudanças que ocorreram na cena contemporânea e, consequentemente, as novas investidas que

\footnotetext{
${ }^{9}$ Observações feitas por Féral em entrevista realizada pelo professor do Departamento de Artes Cênicas da USP, Marcos Bulhões, após a disciplina que ministrou no mesmo departamento. Esta entrevista, em que tive a oportunidade de participar, será publicada na revista Sala Preta, CAC-USP, como parte da série Pedagogia e cena contemporânea, cuja intenção é apresentar um panorama de enfoques teóricos diversos das modalidades do teatro. A entrevista girou em torno das seguintes questões: Quais são as possibilidades pedagógicas presentes no teatro performativo? De que forma a noção de teatro performativo pode estar presente na formação do artista, do pesquisador e do professor de teatro?
} 
acompanharam o modo de atuação e o estatuto do ator em cena. O ator não tem mais como regra a imitação de um papel, tampouco a metamorfose de si em outro, pois já não se vale das categorias do dramático, como aponta Lehmann (2007). Seus investimentos se concentram, na atualidade, em sua subjetividade ${ }^{10}$ e expressividades aglutinadas em sua presença atestada pelo evento - que infere a noção de performer. E, ainda, na sua matéria corpo que se apresenta sob a forma de imagem em situações nas quais se dispõe a agir, intensificando a noção de corporeidade e materialidade da cena.

A seguir, trataremos de algumas noções que nos parecem pertinentes ao teatro que se manifesta na atualidade, a saber, a questão do referente, as noções de teatralidade e performatividade e, ainda, a tensão entre o real e o ficcional. Acreditamos que tais noções, retiradas das reflexões dos autores supracitados, circunscrevem alguns princípios que operam a cena contemporânea e fomentam determinado modo de atuação, que será alcançado na segunda parte do estudo.

\section{0 referente}

Se este novo modo de fazer teatral se refere a "um teatro que não procura mais reproduzir, ainda que de longe, um microcosmo fictício" ${ }^{11}$, estamos tratando de uma cena que não tem como pressuposto a representação de um referente, neste caso, o texto dramático e as ideias dadas previamente pelo autor. Ainda que se trabalhe com um universo referencial, este é tão somente um ponto de onde partem e se cruzam as criações que se desenvolvem a partir da cena e não finalidade, ponto de chegada. $O$ artista deste novo teatro não pretende convergir as possíveis leituras de sua obra para um centro de ideias, de modo que os signos

\footnotetext{
${ }^{10}$ O campo conceitual da subjetivação surge no trabalho de Foucault em que discute a relação de poder e os mecanismos e processos de objetivação e subjetivação do indivíduo. Ele recusa a forma universal do sujeito, considerando que o sujeito não é uma substância, mas forma e experiência. Seu problema "não era definir o momento a partir do qual alguma coisa como o sujeito apareceria, mas sim o conjunto dos processos pelos quais o sujeito existe com seus diferentes problemas e obstáculos" (Foucault, 2004, p.261). Na tentativa de definição do termo, Guatarri encerra uma noção provisória em que a subjetividade seria "um conjunto de condições que torna possível que instâncias individuantes e/ou coletivas estejam em posição de emergir como território existencial auto-referencial em adjacência ou em relação com uma alteridade ela mesma subjetiva". Guatarri. Caosmose, p.19.

${ }^{11}$ Lehmann, H-T. Teatro Pós-Dramático. São Paulo: Cosac Naif, 2007.
} 
presentes em uma representação cênica estejam dispostos para serem decifrados em relação a um referente preexistente. O que envolve o espectador não é a trama ou o enredo, tampouco o encadeamento lógico das ações, como acontecia no paradigma orientado pela poética do drama, mas sim as relações e conexões que podemos estabelecer entre os elementos materiais da cena. Nesta perspectiva, se nos valermos do teatro pós-dramático, ele está mais preocupado com a forma e com a percepção desta forma do que centrado em um conteúdo que pretende uma moral ${ }^{12}$. Dito de outro modo, ele não visa à transcendência ou revelação do mundo das ideias (Platão), nem à imitação de ações humanas (Aristóteles); o espetáculo se fia nos signos dispostos em cena e é a partir de sua própria existência que criamos uma relação estética com o objeto.

É neste aspecto que se pode falar de uma cena autorreferente, não sobre o ponto de vista do artista, que em sua criação também faz uso de seu aparato simbólico para traçar as linhas de sua obra, mas sobre a relação que se estabelece entre a obra e o espectador. O que motiva a comunicação e que pode levar o espectador a traçar planos imaginários em seu campo subjetivo seriam as disposições das formas, os jogos de linguagem, os atores no seu modo de ser aqui e agora. Seria a partir dos elementos presentes em cena que recolheríamos sinais para estabelecer conexões com o mundo das ideias. Deste modo, a cena se torna a própria fonte e referência material que aciona a imaginação e se desdobra em pensamentos.

O espetáculo, então, como organização de ideias pode se referir a ele mesmo porque cria um universo que se realiza e se basta em si, sem que seja necessária a revelação de uma realidade estabelecida a priori, tampouco a realização de outra coisa que não ele. A cena se torna a própria coisa, funda suas leis e, na presentificação material de sua existência, instaura uma realidade de matéria expressiva.

Ao nomear as novas manifestações cênicas como um Teatro Performativo, a pesquisadora francesa leva em consideração a definição de Jacques Derrida para quem o

\footnotetext{
$12 \mathrm{O}$ autor sugere que o Teatro Pós-Dramático modifica nossa percepção do mundo, o qual não se vale mais por narrativas totalizantes e defende que este tipo de teatro tem uma finalidade política, não por defender uma moral e sim por se ocupar da percepção de temas e conteúdos políticos. Lehmann está preocupado com o modo de perceber o mundo e as mudanças visíveis que acompanham as expressões artísticas em função das novas relações que se estabeleceram no mundo contemporâneo.
} 
performativo "não tem um referente [...] fora dele, antes dele, ou diante dele. Ele não descreve algo que existe fora da linguagem ou antes dela. Ele produz ou transforma uma situação, ele opera" $^{13}$. Tal caracterização do termo que acompanha um tipo de teatro valida, portanto, uma cena que faz operar seus componentes no momento em que ela se manifesta. Ou seja, a ação cênica neste caso pode ser tratada como um evento de modo que aquilo que acontece em cena simplesmente acontece sem a obrigação de representar outra coisa. Assim, a cena liberta do referente se realiza como "ato puro", que não antecede a nada e que não que ser outra coisa além dela, ela é em si um acontecimento. ${ }^{14}$

Sob o selo da performatividade, tratado como evento e liberto do referente, o teatro atual traz consigo a marca da experiência (Lehmann, 2007). Público e artista partilham uma situação provocadora e desafiadora, no qual o objeto apresentado é antes um elemento que desencadeia um processo no observador, tanto quanto no observado, que pode excitar uma experiência singular e significativa. $O$ ator se coloca em cena como alguém que age em determinada situação e segundo o contexto do próprio evento. Suas ações não têm finalidade moral e, se há referente em sua composição, ele não é revelador de nada.

Vale ressaltar que não destituímos a noção de representação que acompanha o fenômeno teatral, pois acreditamos que o princípio da teatralidade e suas características estão ali latentes. No entanto, chamamos a atenção para a descentralização da noção de representação: os sentidos oferecidos pela obra se baseiam mais no que ela oferece enquanto matéria concreta e nas relações que estabelecemos a partir dela, do que em um referente preexistente. Neste contexto, acreditamos que cena atual deslocou o foco da condição do intérprete: se ele se prestava à imitação, o que o ligava a um referente, agora se ocupa do fazer, o que o liga à ação no evento.

\footnotetext{
${ }^{13}$ Derrida, J. apud Féral, 2009, op. cit.

${ }^{14} \mathrm{O}$ acontecimento pode ser tratado como algo que acontece no tempo do aqui e agora: o tempo presente se consumindo como aquilo que foi e aquilo que já não é mais; um ato que se dá em um tempo que contém em si passado, presente e futuro, ao mesmo tempo.
} 


\section{Teatralidade e performatividade}

Féral apresenta a teatralidade e a performatividade como dois paradigmas que auxiliam na reflexão acerca das produções contemporâneas. É, portanto, na fricção destas duas noções e na conjugação de seus princípios que a autora nomeia esta nova forma espetacular como teatro performativo, fazendo frente àquela proposta por Lehmann, de teatro pós-dramático.

Apesar dos inúmeros debates acerca do termo teatralidade e sua definição, tomamos como base para este estudo as investigações de Féral apresentadas em seu texto $L a$ Théâtralité: recherche sur la espécificité du langage théâtral (1985). Diante da diversidade em que o termo foi empregado em diferentes disciplinas, de modo divergente e, por vezes, contraditório, a autora se questiona sobre seu emprego e ao que ele se refere quando usado dentro do domínio do teatro. Como o próprio título do artigo deixa claro, a autora parece ainda se debater sobre uma especificidade desta linguagem artística e sobre o que a diferencia das outras áreas. De fato, tal ponto de vista parece ter algo de essencialista e idealista, no sentido de procurar uma unidade que determinasse uma natureza própria desta arte, um domínio exclusivo e específico que a diferenciasse das outras artes. No entanto, este texto traz em seu princípio um questionamento que o retira deste lugar: "Deve-se falar de teatralidade no singular ou de teatralidades no plural?" e mais, tal noção, "Seria ela, uma propriedade do teatro ou ela pode, do mesmo modo, investir sobre o cotidiano?" Parece-nos que autora procura antes os meios e os modos de emergência da teatralidade, do que uma definição que garanta a excelência do teatro e, ainda, o que o diferencia das outras artes.

O fato é que o termo já foi tratado como aquilo que orbita no senso comum, isto é, a ideia de que o teatro seria algo dissimulado, fingido e enganoso, o que abriu margem para toda uma linhagem antiteatral, de negação à "arte do engano", que vimos evoluir ao longo do século XX e que se mostrou como força potente para as experiências cênicas e mais ainda para a arte do ator $^{15}$. Patrice Pavis (1999) traz em seu dicionário uma reflexão sobre o termo que trata a teatralidade como aquilo que "na representação ou no texto dramático é especificamente

\footnotetext{
${ }^{15}$ Sílvia Fernandes esclarece o tema em seu ensaio intitulado "Teatralidades Contemporâneas", que pode ser lido em Texto e imagem: estudos de teatro, organizado por M. Helena Werneck e Maria João Brilhante, da editora 7 Letras, 2009. p. 9-27
} 
teatral (cênico)", o que na voz de Artaud entende-se como "tudo que não obedece à expressão pela fala, pelas palavras, ou se quisermos, tudo que não está contido nos diálogo (e o próprio diálogo considerado em função de suas possibilidades de sonorização em cena, e exigências dessa sonorização)". Tal concepção evidencia que Artaud se contrapõe à forma tradicional do teatro europeu. No entanto, não podemos negar que sua posição fundiu, definitivamente, toda uma linhagem teatral - de teoria e prática - que passou a enfatizar os aspectos materiais da cena, bem como a exploração dos recursos corporais e vocais dos atores. Na mesma trilha, encontramos a definição de Ryngaert, segundo o qual a teatralidade seria "um caráter que se presta à representação cênica" ${ }^{16}$, ou ainda de Barthes como sendo tudo aquilo que comporta a materialidade da cena e que está disposto no evento teatral: "o teatro menos o texto [isto é] uma espécie de percepção ecumênica dos artifícios sensuais e gestos, tons, distâncias, substâncias, luzes que submergem o texto sob a plenitude de sua linguagem exterior". No entanto, Pavis chama a atenção para o fato de não podermos definir o teatro e sua essência como sendo somente a espacialização, visualização e expressão do temas e conteúdos que são oferecidos pelo texto. E seguindo os passos de Féral, preferimos tratar da teatralidade mais pelo seu caráter dinâmico de processo de constituição de teatralidade, do que de seus aspectos extratextuais, ou de textualidade cênica.

Féral observa em seus estudos que o termo pode ser pensado para além do teatro, não o tratando, assim, como essência desta prática artística, mas antes, como uma ferramenta cênica que nos permite refletir acerca das produções teatrais. Para tanto, a autora testa a possibilidade de sua existência para fora da esfera teatral, ou seja, a possibilidade de irromper na esfera do cotidiano de modo que consolida sua acepção acerca do conceito: antes de tudo, a teatralidade se torna um processo. "Mais do que uma característica que marca o feito teatral, a teatralidade seria um processo que depende do investimento do sujeito diante de uma realidade" 17 . Ela está impressa no "olhar que liga o observado - ator, objeto - e o observador espectador", o que significa que a teatralidade pode ser produzida por iniciativa do ator, que manifesta sua intenção de jogo, ou pelo espectador, que transforma o outro, por iniciativa

\footnotetext{
${ }^{16}$ Ryngaert, J.-P. Ler o teatro contemporâneo. São Paulo:Martins Fontes, 1998.

${ }^{17}$ Féral, J. La Théâtralité: recherche sur la esécificité du langage théâtral. Poétique, n. 75, 1988, p.347-61
} 
própria, em objeto espetacular. Assim, diante de um fato, o indivíduo pode produzir conscientemente um espaço de ficção, uma realidade outra, ao projetar sobre ele certa qualidade estética. Assim é que o ato consciente de produção de teatralidade pode vir do próprio ator, que pode atuar com intencionalidade, ou do observador, que pode imprimir uma qualidade estética sobre o acontecimento, o comportamento, o corpo, o objeto e o espaço.

Deste modo, podemos pensar na condição da existência da teatralidade em termos de identificação, quando ela é ambicionada pelo outro, isto é, quando o ator se insere em um universo ficcional e o espectador identifica tal investimento. Ou podemos ainda tratá-la em termos de criação, isto é, quando um indivíduo instaura um espaço diferente do cotidiano, estetizando as coisas e criando, através de seu olhar, um espaço diferente do qual ele permanece $^{18}$. Como ato consciente do ator ou do espectador, a teatralidade depende de um olhar ativo, que qualifica o que se vê e aciona um espaço diverso do cotidiano. Ou seja, o indivíduo abre uma fenda no espaço real e projeta, por meio de suas operações mentais e imaginativas, um olhar distanciado da realidade, promovendo assim, a alteridade ${ }^{19}$.

Da instauração da teatralidade emerge a alteridade à medida que um (ator) se torna outro um (ser ficcional), seja porque aquele manifesta o desejo pela representação, seja mesmo pela relação que se estabelece entre observado e observador. Isto é, o outro (espectador) transforma o um (ator) em outro um (ser/objeto ficcional). Logo, a teatralidade permite àquele que faz e àquele que observa uma passagem para outro lugar. Em outras palavras, ela autoriza o espaço da ficção e marca um sujeito em processo: a teatralidade “(...) é um ato performativo daquele que observa e daquele que faz" ${ }^{20}$. Portanto, ela não é uma manifestação física, como vimos anteriormente nas definições de alguns teóricos, tampouco ela é dada empiricamente as coisas não possuem uma qualidade determinada. A teatralidade seria, antes de tudo, uma execução do sujeito em relação ao mundo e em relação ao seu imaginário: “O investimento das

\footnotetext{
${ }^{18}$ Féral, J. 1988, Idem.

19 J. Féral afirma que a alteridade é um elemento constitutivo do fenômeno teatral, de modo que o termo acompanha o teatro desde suas manifestações. A autora estaria com isto determinando uma essência do teatro?

${ }^{20}$ Féral, 1988, Idem
} 
estruturas do imaginário fundadas sobre a presença do espaço do outro que autoriza a teatralidade." 21

Assim, o terreno da teatralidade nos aproxima de um universo ficcional, de organização de códigos e de construção de sentidos, ligado ao reconhecimento mimético e à natureza da representação, acionada pela imaginação. Ela não depende do objeto, do ator, ou da situação para ser operada, ela seria o resultado de um olhar dinâmico que une o observador e o observado. Ou seja, a teatralidade não é algo dado a priori, ela se mantém em potencial e pode ser pensada como um processo que registra

\footnotetext{
“(...) um ato de representação e a construção de uma ficção. [Assim], a teatralidade aparece como a imbricação de uma ficção em uma representação em um espaço de alteridade que coloca frente a frente um observador e um observado. Dentre todas as artes, o teatro é o lugar onde se melhor efetua esta experiência".
}

Esta acepção torna-se fundamental para nós, pois o ator pode se colocar à vista do espectador e oferecer a ele a constituição de uma teatralidade, sem que ela seja produzida anteriormente pelo próprio ator - ainda que ele esteja em um espaço que se pretende como um campo de projeção ficcional. No entanto, o ator não precisa indicar o que o observador tem que observar, não lhe é mais necessário apontar e forçar a leitura de algo - não há preexistência - o ator pode apenas fazer o que deve ser feito em determinada circunstância e, assim, oferecer ao espectador imagens (espaciais, sonoras e materiais) para que este lance mão de sua imaginação, finalizando a obra segundo seus próprios recursos psicoafetivos: ocorrerá a organização simbólica, porém ela não será definida pelo ator, ele poderá apenas emitir sinais por meio de suas ações para que o espectador faça seu sobrevoo imaginativo.

\footnotetext{
${ }^{21}$ Para este debate Féral traz à luz as discussões incitada por Evreinov, sobre a possibilidade de transcendência do homem a partir de sua necessidade instintiva, de sua disposição inata de 'vontade de teatro', que diz respeito à qualidade universal do gosto pelo travestimento, pelo prazer em gerar ilusão, de projetar fiç̧ão, de uma experiência lúdica e de transformação da natureza. Este comportamento está ligado ao homem antes mesmo de se tornar um ato estético. Segundo a autora, tal concepção diria respeito a um campo pré-estético, na medida em que este modo de operação incita a criatividade e pode resultar em um ato estético. Para saber mais, ver Féral 1988 , p. 352 e 360.
} 
Paralelamente às redefinições e tentativas de resgate positivo da questão da teatralidade, vemos historicamente o desenvolvimento das artes performáticas e de seus princípios que foram se anexando, paulatinamente, à arte do teatro. A performance está relacionada ao momento histórico das vanguardas do início do século, do movimento antiteatro que rejeitava os aspectos da prática do teatro tradicional, enfatizados pelo enredo, caráter e pela referencialidade, em favor de uma relação mais livre com a obra, estabelecida por um contato mais direto entre artista e espectador e no uso de diferentes linguagens artísticas no mesmo evento. Para tanto, insistia na presença física do artista de caráter autobiográfico, no sentido de que ele agia e falava em seu próprio nome (como artista e pessoa) e mantinha uma relação direta com o objeto, com o espaço e com a situação que se dispunha a viver. A performance constituía-se, também, como um evento não repetível, que acontecia uma vez em determinado lugar, em um espaço e tempo presentes. Finalmente, os artistas pretendiam, com isso, escapar à representação e à organização simbólica que reinavam nas formas teatrais.

Provém destes princípios elencados a noção de performativo que acompanha a definição desse novo teatro proposto por Féral (2008). Tal conceito, inicialmente foi desenvolvido no âmbito dos estudos da linguagem, tendo Austin e Searle seus principais precursores, sendo difundido, mais tarde, nas práticas cênicas, pelo desenvolvimento da Performance Studies - da qual Richard Schechner é seu principal artista. Tal conceito, somado às características da performance, leva a refletir sobre alguns princípios que afetaram definitivamente as práticas artísticas e possibilitaram uma atuação propositiva e dinâmica por parte do ator. Isto é, a ênfase na ação real do artista em cena potencializado por seus fluxos energéticos - gestuais, vocais, libidinais. Uma investida que se opõe ao ato de representar e da metamorfose do ator em personagem.

De modo sintético, a noção de performativo dentro das categorias da linguagem diz respeito às palavras em um discurso que, ao serem proferidas, modificam efetivamente o curso das coisas. Austin considera o ato performativo como uma expressão da linguagem, quando alguém diz alguma coisa que age diretamente sobre a realidade - To say something is to do something (dizer algo é fazer algo). Dizer torna-se, portanto, sinônimo de ação, uma vez que a fala instaura 
uma nova realidade, pois seu pronunciamento não descreve ou representa uma situação, ela é a própria ação ${ }^{22}$. O performativo cria, assim, uma ação a partir de seu dizer. Uma obra considerada performativa, dentro do campo das artes literárias, seria aquela que não está preocupada em "representar" algo, mas que instaura, em cada enunciado performativo, uma nova realidade. Podemos dizer, com isso, que o performativo qualifica uma obra que enfatiza a realização da ação e atenua a representação. E mais, ao primar pela ação, ela projeta o evento, no sentido em que algo acontece em determinado momento em dado contexto.

Esta característica do performativo, transposta para o campo das artes cênicas, valida uma representação sem reprodução ${ }^{23}$ determinada pela singularidade de viver e agir naquele momento presente em que algo acontece. Do mesmo modo que a fala performativa não descreve ou representa uma situação, a ação performativa age sobre a própria realidade que se vive. O ator não quer dizer eu estou fazendo isto, ele está realizando; ele não diz que manca, ele manca; ele não diz que está cansado, ele se cansa. Logo, a ação não está contida no enunciado, ela acontece e se realiza, ela é o próprio movimento das coisas.

Outro ponto elementar para pensarmos sobre a cena numa perspectiva performativa é o dado acrescentado por Schechner para quem a performatividade é caracterizada pela "desconexão de causa e efeito entre o significado e o mundo" ${ }^{24}$. Isto sugere um resultado estético, ligado ao jogo do intelecto, de obra aberta à recepção daquele que participa ativamente do evento. Pois seu objetivo não é o de produzir signos, mas sim o de deixar-nos flutuar na ambigüidade das significações que vão ganhando vida à medida que algo vai acontecendo. Neste sentido podemos dizer que a performatividade se aproxima da realização, da efetivação de algo e leva em consideração o processo: não precisamos mascarar a realidade da cena, ela está exposta aos olhos do público. Deste jogo de signos emerge o caráter lúdico da obra: neste momento encontramos o prazer em participar dos fios que enlaçam suas tramas. Se

\footnotetext{
${ }^{22}$ Schechner, R. "Performativity" In. Performance Studies: an Introduction. New York \& Londres: Routledge, 2006, p.p. 123-169.

${ }_{23}$ Peggy Phelan, apud Janelle Reinelt, The Politcs of Discourse: Performativity meets Theatricality. University of WisconsIn. Substance, vol. 31. PP 201-215.

${ }^{24}$ Schechner, Idem.
} 
a obra pode falhar ${ }^{25}$ enquanto objetivo, o risco que provém daí promove certa cumplicidade entre palco e plateia e amplifica o aspecto lúdico da obra, tanto quanto da atuação.

A obra performativa não precisa alcançar um objetivo e, assim, ela está fora do mundo da representação, e mais, o ato performático não quer ser reduzido ao estatuto de objeto semiótico, pois algo nele sempre trasborda e se recusa a funcionar como signo ${ }^{26}$. No entanto, ele não é reducionista e sem referencial, de fato ele trabalha na torção, na desconstrução, na perversão do referencial e da própria performatividade ${ }^{27}$. De modo que tudo que está em cena e que leva o princípio da performatividade pode estar em potência ou em ato. Isto é, alguma coisa que pode ser outra ou alguma coisa que está realizada. ${ }^{28}$

E mais, seu foco estaria centrado na ação de modo que o termo deriva do verbo inglês to perform: fazer, realizar, efetuar. O que significa dizer que performar é sinônimo de algo que realmente acontece, e mais, alguém ou alguma coisa age para que alguma coisa ocorra. Se performar é realizar, a condição do performer é agir para fazer algo em cena. E, se ele pretende promover uma modificação na realidade em que está agindo, ele promove uma ação performativa. O teatro performativo chama para si o princípio do fazer e seria caracterizado por se afastar da reprodução de algo, enfatizando o caráter processual de uma obra que se instaura como evento. Dito de outra forma, a cena acontece mediante a realização de uma ação do performer, que está sendo feita no momento presente em que ocorre sua efetivação. E, ainda que tal ação tenha sido previamente elaborada, ela pode ser considerada como uma representação, porém, ela não é uma reprodução. Pois, se o performer promove uma ação

\footnotetext{
${ }^{25}$ A noção de performativo definida pelos filósofos da linguagem foi revisada e criticada pelo filósofo francês Jaques Derrida, no campo das obras literárias. Porém, para Féral, quando Derrida afirma que a ação, que está no enunciado performativo, pode ser efetiva ou não, e que ela deve ser pensada segundo o contexto em que está inserida, a performatividade não pode ser julgada como verdadeira ou falsa, de modo que a falha e o risco seriam constitutivos do termo. Féral acredita que Derrida legitima seu uso para além das obras literárias. (Féral, 2008). Esta é uma resposta de Derrida a Austin para quem a performatividade só poderia ser pensada em circunstâncias ordinárias, de modo que atores no palco, um poema, ou um monólogo, não efetivam um enunciado performativo. Em tais casos, os "enunciados são parasitas de sua utilização normal". (Austin apud. Schechner, 2006, op. cit.)

${ }^{26}$ Zumthor, P. Performance Recepção e leitura. São Paulo: Cosa\&Naif, 2007.

${ }^{27}$ Schechner, Idem.

${ }^{28}$ É interessante notar que mesmo as coisas em ato são em potência, já que em ato elas podem se transformar em outra coisa.
} 
performativa, ele modifica a realidade e as coisas acontecem no momento presente em que está sendo realizada. Esta é uma consideração que coloca o performer como agente da cena.

No quadro 1 apresentamos os princípios concernentes à teatralidade e à performatividade, sugeridos por Féral:

QUADRO 1 - Princípios que operam na teatralidade e na performatividade ${ }^{29}$

\begin{tabular}{|l|l|}
\hline Teatralidade & Performatividade \\
\hline Toca no espetáculo & Toca no performer \\
\hline Ponto de vista da recepção & Ponto de vista do ator, da ação, do performer \\
\hline Observa-se o fenômeno do exterior & Observa-se o fenômeno do interior \\
\hline stém-se às estruturas simbólicas, aos & Atém-se às ações, antes de projetar valores \\
\hline $\begin{array}{l}\text { É um resultado (espetáculo - o olhar do } \\
\text { espectador cumpre a ação) }\end{array}$ & $\begin{array}{l}\text { simbólicos } \\
\text { porém não se elimina o valor simbólico) }\end{array}$ \\
\hline
\end{tabular}

Depreende-se, então, é que os princípios que regem cada termo - teatralidade e performatividade - dizem respeito ao ponto de vista que se toma em relação à obra. $A$ primeira poderia ser pensada em termos globais, ou seja, uma cena que é observada do exterior, que propõe uma dimensão simbólica e que tem o espectador como seu principal atuante: a cena vista de fora. A segunda propõe um investimento do sujeito que está inserido na cena, que a observa ao mesmo tempo em que a aciona, e ao operá-la não projeta a priori um significado: é a cena feita de dentro.

Na conjugação dos termos, poderíamos pensar assim: um teatro que tem como origem o sujeito (performer) e que se atém, inicialmente, aos seus aos seus aspectos pulsionais ${ }^{30}$ :

${ }^{29}$ Fonte: Féral (2009), adaptado pela autora 
"um teatro que se investe como fluxo de desejo" ${ }^{31}$. Porém, ao mesmo tempo, por ser operado pela teatralidade, este sujeito permanece inscrito em códigos, estabelece contratos com o público e joga com signos. Assim, existe um teatro que tem um sujeito desejante que se destina a alguma outra coisa. E no processo dinâmico de construção de ficcionalidade, que se opera por meio da teatralidade, temos a constituição de signos que buscam uma comunicação e que promovem a alteridade.

Notamos ainda que as práticas performáticas unidas ao teatro se prestam ao imaginário e, a partir dele, à constituição de uma ficção, à medida que construímos um espaço outro na relação que estabelecemos entre o olhar de fora (espectador) e o olhar de dentro (performer). Isto porque, em princípio, aquele que está dentro investe em sua dimensão corporal e pulsional e pretende um contato presencial com o público. No primeiro momento, aquele que está de fora absorve a dimensão física da cena, tanto quanto a corporeidade do sujeito que ali está presente. No segundo instante, toda esta dimensão material desdobra-se em um campo imaginativo, por meio de elaborações psíquicas, em que é possível a organização do material simbólico. Assim, a imaginação daquele que estava de fora colocou aquele que estava dentro em um campo ficcional: o imaginário construiu uma ficção, o espectador agiu sobre a obra à medida que o performer fazia a obra. O que estabelece esta nova configuração não é o abandono da ficção, mas uma relação diferenciada que se pode estabelecer com ela e com a realidade na qual ela se processa.

Neste sentido, recorremos à proposição de Lehmann (2007), para quem "O teatro ao se aproximar do real, está pronto para desistir da arte para ser realidade, mas sempre recua para o significado antes deste passo derradeiro". Logo, é no terreno da teatralidade que gestos, respiração, voz, movimentos nos direcionam a um sentido, ao passo que, no campo da performance, prestam-se como sinais, índices de algo que pode vir a comunicar algo.

\footnotetext{
30 Trataremos deste termo, especificamente, na segunda parte do estudo. No momento diríamos que seriam os aspectos da atuação que escapam da linguagem, ou se preferirmos dos signos.

${ }^{31}$ Característica enfatizada por Féral e que parece se aproximar da proposta de teatro energético de J. -F. Lyotard, que trataremos quando falarmos do ator na cena, na próxima parte. Por ora, diremos que suas propostas se éeferem a um teatro de intensidades, forças e pulsões, que tenta se afastar da ideia da representação.
} 
Enfim, o teatro que resvala na performance valida ação e processo, além de invocar a experiência real do ato cênico. A cena teatral passa a ser considerada como realidade inscrita, uma presentificação do tempo, do espaço e do ser, ao mesmo tempo em que está encapsulada no tempo, espaço ou ser. Dito de outro modo, o evento ocorre, mas é circunscrito num universo ficcional.

Tratar da friç̧ão entre estes dois conceitos nos interessa à medida que podemos aglutinar, no mesmo evento, a operação de ambos os termos. De modo que a performatividade permite ao ator se libertar das amarras da imitação de ações humanas, podendo tornar-se o próprio sujeito que age em determinada circunstância e que opera a realidade em que está inserido: uma relação real sustentada pela sua subjetividade e corporeidade expressiva, que lhe oferece liberdade para agir. Em contrapartida, a teatralidade que constitui o processo de ficcionalização, da construção de um mundo imaginário que o desloca da realidade inserindo-o num espaço não cotidiano. Assim, o ator está ao mesmo tempo dentro e fora. Dentro porque age em uma situação real. Fora porque ele é jogado para o mundo da representação, da construção imaginária de uma realidade outra, enfim, para o espaço da alteridade. A teatralidade e a performatividade fazem dele um ser que permanece num estado limite entre realidade e ficção.

Esta operação parece inscrever na cena outra prática que cada vez mais ganha espaço nas encenações atuais: a tensão entre o real e o ficcional.

\section{Entre o real e o ficcional}

Precebe-se o teatro contemporâneo ${ }^{32}$ dar ênfase à tensão que se opera entre a realidade e a ficção. Esta prática não é própria da atualidade, pois em todos os tempos, o conflito entre a realidade e a ficção perseguiu o teatro em função de sua própria natureza - o teatro sempre se apresenta por meio de corpos reais, em espaço real e em tempo real. O fato é que o real puro é uma abstração, pois a representação nunca deixa de existir na cena teatral.

\footnotetext{
32 Tratamos de teatro contemporâneo para não fixá-lo como um teatro performativo ou um teatro pós-dramático, já que falamos das características que estão na natureza das práticas que acompanhamos atualmente.
} 
Assim como a ficção pura também é uma abstração, pois a realidade nunca deixa de se apresentar no evento teatral. Estas tensões existentes nas práticas atuais podem ser vistas em relação ao tempo e ao espaço - real e ficcional, assim como, aos personagens e aos atores ficcional e real.

Para tratar desta aporia, a professora, pesquisadora e teórica alemã, Érika Fischer-Lichte dedica-se a refletir sobre a ordem da presença e a ordem da representação. Em seu artigo intitulado Realité et ficcion dans le téâtre contemporain, defende a tensão entre estes dois polos como princípios presentes no teatro da atualidade, e mais, de como o seu uso influencia na percepção da cena.

No que diz respeito ao ator, a ordem da presença seria aquela que se refere ao tratamento dado ao "corpo real, dito fenomenal, do ator, isto é, seu ser-no-mundo-corporal” ${ }^{33}$, caracterizado pela concretude das coisas dispostas em cena. De certo modo, estamos tratando do campo material da cena, dos aspectos físicos do ator, de seu corpo enquanto imagem material ${ }^{34}$.

A ordem da representação, por sua vez, trata daquilo que pertence ao universo ficcional, ou mesmo, daquilo que produz sentido em uma encenação. Em relação ao ator, ela diz respeito àquilo que é percebido e que se refere ao personagem dramático. Neste caso, não é o imaginário que está agindo, mas sim as relações que construímos a partir das estruturas simbólicas oferecidas pela própria encenação, como a narração, o discurso, de modo que o ator cumpre uma função na organização dramatúrgica.

Para Fischer-Lichte a ordem da presença - que parece ser aquela própria da performance - aciona a projeção do imaginário e nos conduz "a associações, sonhos, memórias, fantasmas", que provêm da coisa observada. De certo forma, tal percepção nos leva de volta à noção de teatralidade enquanto processo, como sugerida por Féral (1985) e explorada anteriormente. Mas a autora alemã acrescenta um dado que nos parece relevante:

\footnotetext{
${ }^{33}$ Fischer-Lichte, E. "Realité et ficcion dans le téâtre contemporain". Em Registre 11/12, Paris: Sorbonne/Nouvelle, 2007.

${ }^{34}$ Este aspecto pode ser pensado como um tratamento de coisificação do ser humano, o qual Lehmann apresenta como material significativo da arte performática. No entanto, como sugere o autor, este aspecto não será foco de nossas atenções, pois o que nos interessa é a tensão qualitativa que isto infere na cena atual.
} 
muitas vezes as operações imaginárias podem não estar relacionadas diretamente ao objeto percebido. Isto é, ainda que o olhar se fie na corporeidade, na singularidade do corpo observado, as associações produzidas a partir desta materialidade nos levam a outros tipos de percepções que não dizem respeito, necessariamente, àquilo que está sendo observado. De maneira que quando esta percepção ligada à presença estabelece processos perceptivos, a produção de sentido torna-se imprevisível. Isto parece estabelecer contato com a proposta de conjugação entre teatralidade e performatividade. Ou seja, a teatralidade, quando projetada sobre o outro, pode estabelecer processos dinâmicos de constituição de um universo ficcional. No entanto, no que tange à performatividade, ela estaria atuando na desconexão entre causa e efeito do mundo: aquilo que se vê desperta um apreciação simbólica do espectador, porém ela não estaria, necessariamente, ligada a um significado, ou sentido, que poderia estar indicado na obra. Ora, jamais podemos prever os significados produzidos pelas associações, nem tampouco predizer qual significado orienta a percepção em direção a um elemento teatral em particular. A instabilidade desta percepção, portanto, acarreta certa imprevisibilidade, pois o processo de percepção que emerge a partir da presença é algo que o ator não tem controle.

Além disto, a autora enfatiza como estas duas ordens são exploradas ao limite na cena contemporânea. Isto é, não se pretende a preponderância de uma sobre a outra, e sim um constante vai-e-vem entre ordem de presença e ordem de representação. Deacordo com a pesquisadora, isto cria certa instabilidade na percepção dos sentidos produzidos pela cena. Para Fischer-Lichte tal instabilidade nos conduz - palco e plateia - a uma experiência limiar ${ }^{35}$, pois, mesmo que empreguemos todos os esforços para compreender o que se passa em cena, e mesmo que a ordem da representação sugira um discurso, nada parece finalizado, tudo parece

\footnotetext{
${ }^{35}$ Fischer-Lichte toma o termo emprestado dos estudos antropológicos. Segundo Roberto da Matta, a liminaridade pode ser tratada como algo "invariavelmente paradoxal, ambíguo e, no limite, perigoso e negativo; isto é, como um estado ou processo que desafia um sistema de classificação legalisticamente concebido como fixo, indiscutível e construído por categorias isoladas"; Nas palavras de Victor Turner: "Os atributos de liminaridade, ou de personae (pessoas) liminares são necessariamente ambíguos, uma vez que esta condição e estas pessoas furtam-se ou escapam à rede de classificações que normalmente determinam a localização de estados e posições num espaço cultural. As entidades liminares não se situam aqui nem lá; estão no meio e entre posições atribuídas e ordenadas pela lei, pelos costumes, convenções e cerimonial. No que tange ao ator, este termo parece falar da natureza da atuação. De fato, seu paradoxo é permanecer na fronteira: ele é EU mas também OUTRO, ou nas palavras de Schechner, ele é um "não eu e um não não eu" ao mesmo tempo.
} 
estar em constante potência de vir a ser algo. Quando conseguimos capturar algo sinalizado por uma ordem, em seguida recebemos a contragolpe outro sinal de que a coisa já não é mais. De fato, se as ordens da presença e da representação permanecem instáveis, isto perturba a possibilidade de algo ser tomado como significado definitivo. Porém, o interessante é que este abalo parece ser justamente o que nos mantêm pregados à cena.

O fato é que no momento do deslizamento entre a ordem de representação e ordem da presença, na ocasião em que tudo permanece instável, o sujeito fica "em um estado entre dois". Este espaço do entre parece ser análogo ao princípio da performatividade, no sentido de que algo (uma ação, uma fala, uma luz) infere uma ruptura na continuidade (linearidade) das coisas, de modo que a organização simbólica torna-se inapreensível. Seria, portanto, a instabilidade ocorrida no deslizamento dos sentidos, na superposição de signos, o que leva o espectador a navegar à deriva.

A tensão que se opera na cena atual entre ficção e realidade, este constante vai-e-vem do espectador, tanto quanto do ator, entre uma e outra ordem e a instabilidade da percepção que este movimento instaura valida tratar a cena em termos de processo. Tal fato nos aproxima do caráter performativo de uma obra, entretanto, somos acionados pela teatralidade que promove uma passagem para algum lugar outro.

Levamos em consideração, ainda, a ideia de encenação aferida pela autora: "a encenação se realiza no tempo presente e se modifica em função da presença do público e do contato do artista com este público" ${ }^{36}$. Ou seja, a encenação não seria apenas uma moldura construída anteriormente pelos criadores da cena, ela se realiza quando colocada em contato com o público. Visto deste ângulo, o ator em cena está disposto à realidade do acontecimento cênico. Suas atitudes, gestos, pausas se modificam no contato imediato com seu público. Ele percebe a situação e faz uso disto incorporando na cena as modificações causadas por este

\footnotetext{
${ }^{36}$ Fischer-Litche apresentou sua acepção de encenação em minicurso realizado no Projeto Próximo Ato no Itaú Cultural em São Paulo: "O que acontece no entremeio - Teatro como espaço limiar". Na ocasião, trouxe outro olhar sobre o conceito de encenação: a encenação deve ser tratada mais pelo conjunto de forças que se operam no presente instante da cena (atores, público e espaço), do que tomada por aquilo que foi predeterminado na sala de ensaio. Para a pesquisadora, há um círculo que se instaura no espaço cênico que aciona mudanças no momento presente da cena: $o$ ator age, o público reage, o ator reage, o público reage e neste ciclo ininterrupto a encenação se torna dinâmica e jamais se fixa.
} 
encontro. Isto conduz sua atuação a certa instabilidade, de modo que o ator se sustenta em cena no entre-meio, isto é, entre a ordem da representação e a ordem da presença. Em outras palavras, a exploração da tensão entre o real e o ficcional legitima um ator que investe na natureza de sua própria condição: ser ele sem o ser e, ao mesmo tempo, sendo outro sendo ele. Ou mesmo como propõe Schechner: "O ator deve ser capaz, até certo ponto, de ser dois em um, de se manter ao lado de si mesmo e de se ver a si próprio" ${ }^{37}$.

É interessante destacar o movimento entre estes dois pólos e as consequências que isto produz na prática cênica atual. Ou seja, observamos a presença ao mesmo tempo em que especulamos a representação. Não desejamos fixar os limites entre uma e outra ordem, o que interessa é o constante movimento entre uma e outra, sua sobreposição e sua disjunção. E seguirmos incitados pela declaração de Lehmann:

“O essencial é notar que não é a afirmação do real em si (como nos produtos sensacionalistas da pornografia), mas a incerteza, por meio da indecidibilidade, quanto a saber se o que está em jogo é realidade ou ficção. É dessa ambiguidade que nascem o efeito teatral e o efeito sobre a consciência" ${ }^{38}$.

${ }^{37}$ Schechner, R. A emoção que se quer despertar não é a do ator, mas a do espectador. Entrevista concedida a Josette Féral em Mise em scène et jeu de l'acteur. Montréal (Quebec) /Carnières: Jeu/ Lasman, 2001. Trad. José Ronaldo Faleiros.

${ }^{38}$ Lehmann, idem. p. 165. 


\section{PARTE II - O ATOR NA CENA}

"Permaneceremos sempre

entre a forma disciplinada e a irrupção caótica do corpo". Lehmann (2007)

A ideia de uma estrutura clássica como um passado conhecido que determina um presente estável e que leva a um futuro inevitável não faz mais sentido dentro desta acepção de teatro. Pois estamos diante de uma cena que não se resume em narrar uma história de ação completa que pressupõe um passado, vive o presente e indica um futuro. Tampouco se define por um personagem com história pregressa que determina o presente de seu drama. E mais, se o ator, no teatro psicológico, dito realista, dispunha-se a viver um personagem, aderindo à realidade ficcional, fazendo com que seu corpo fenomenal desaparecesse completamente atrás do corpo semiotizado ${ }^{39}$, podemos perceber, na cena que se desenrola, uma atuação que não tem mais como objetivo a representação do personagem. Mas, então, o que resta?

\section{Corpo imagem}

Sob o ponto de vista da cena que enfatiza sua materialidade, digamos que, no que se refere ao ator, ao retirar o cosmo fictício da cena teatral, o corpo tornou-se realidade material, mediador da relação que se estabelece entre palco e plateia, além de ser o lugar em que formas podem ser dimensionadas ${ }^{40}$. Ao renunciar os artifícios tradicionais que dissimulavam e transformavam o corpo do ator em outro, parece-nos que este corpo agora entrega-se como realidade carnal: seu peso, sua altura, seu traços tornam-se meios de comunicação. Advém disto, o uso e a exploração dos recursos do corpo e a consciência por parte do sujeito que este recurso pode ser, ao mesmo tempo, um ou mil corpos: ele dispensa os artificialismos e procura em seu corpo a diversidade de formas que pode gerar.

\footnotetext{
39 O corpo ficcional do personagem implica, no teatro realista, um gesto totalizante que pretende criar uma completa ilusão da realidade.

${ }^{40}$ Lehmann, op. cit.
} 
Segundo Pavis (1999) na tendência do teatro experimental, que consideramos aquelas que tentam, a seu modo, explorar o teatro para além de seu aspecto textual e psicológico, “o corpo material proclama-se autorreferente" ${ }^{41}$. O que significa dizer que ele não é mais um meio de expressão de uma ideia ou de uma psicologia, e sim, remete-se a si mesmo, de modo que seria a partir do seu corpo - que o ator domina e maneja - que ele realiza movimentos e cria gestos. Ou seja, o espaço ${ }^{42}$ do corpo pode ser encarado como princípio criativo de onde se originam as formas, os gestos, as sonoridades. Este aspecto de autorreferência concernente ao corpo do ator parece ter reverberações nos mesmos princípios da cena que pretende fundar sua própria realidade. Isto é, do mesmo jeito que o espetáculo se insere como realidade autônoma que não quer ser a realização de um cosmo fictício estabelecido a priori, o corpo do ator não seria mais um espaço de encarnação de um personagem, não seria mais um mediador das ideias do autor, mas, antes de tudo, seria material e concreto que pode gerar imagens a partir das dinamizações de sua própria forma. Nesta exploração, ele pode criar tanto formas codificadas, possíveis de identificação, como formas que escapam de qualquer ficcionalização.

Parece-nos assim, que as práticas experimentais, ao se afastarem do teatro centrado no texto e na palavra realizam a projeção de Artaud e pensam a

\section{“(...) cena como um lugar físico e concreto que pede para ser preenchido e que se faça com que ela fale sua linguagem concreta (...) essa linguagem material e sólida através da qual o teatro pode se distinguir da palavra (...)".}

Pode-se dizer, então, que quando o teatro como representação fiel da realidade foi substituído pela ideia de um funcionamento da cena enquanto escritura no espaço, a presença do corpo passa a ser um fator central: a condição física do corpo foi enfatizada pela materialidade do evento. O corpo do ator passa a ser tomado por sua realidade presente, matéria de potência expressiva e comunicativa, sendo um vetor que une palco e plateia. Acreditamos que a variedade de seus recursos e meios foi amplificada em cena à medida que a palavra foi perdendo seu status.

\footnotetext{
${ }^{41}$ Patrice Pavis. Dicionário de teatro. São Paulo: Perspectiva, 1999.

42 Grifo espaço por falta de outro termo, já que me parece que, nos debates contemporâneos acerca do corpo, este tem sido tratado cada vez menos como um espaço, suporte ou meio, mas como unidade orgânica, que pensa, que tem vísceras, sensibilidades, emoções, que age, etc.
} 
Mas este corpo, que passou a ser pensado como matéria, pode ser visto, também, como signo $^{43}$ no teatro cuja natureza ainda parece reforçar uma representação. E o corpo resultante desta cena não poderia ser aquele dominado por forças cotidianas, entregue às disposições do momento e que se moveria em cena de forma habitual. Ele, inscrito em cena, passa a ser um signo que faz parte de todo o sistema da enunciação espetacular e, portanto, deveria ser treinando e codificado de modo a corresponder à espessura semântica desta realidade, pois "o homem em sua materialidade corpórea, possui a habilidade de construir, através do corpo, sistema de significações." 44

Remete-se, neste aspecto, nos hieróglifos de Artaud e Grotowski, no corpo da biomecânica de Meiehold, na supermerionete de Craig e no conceito de ação física de Stanislawisk, para citar apenas estes ${ }^{45}$. Apesar das diferenças mantidas segundo as orientações artísticas de cada um, todos se empenharam (ou projetaram) em desenvolver técnicas e treinamentos que exploram o corpo do ator, de modo que um intérprete dentro de um tipo de teatro, ou que gera a criação de um tipo de teatro, necessita de determinado desempenho e busca meios para tal. No que diz respeito ao trabalho de treinamento técnico e de procedimentos diversos, independentemente das opções artísticas, nos referimo-nos à busca de um corpo educado, instrumentalizado e informado, "uma técnica em que o corpo é o próprio instrumento, objeto técnico e meio para atingir um fim" ${ }^{46}$. Por meio da técnica e do treinamento, os atores poderiam apelar para o corpo de modo específico, desenvolver uma

\footnotetext{
${ }^{43}$ Signo aqui será tratado como sendo qualquer coisa que representa alguma coisa para alguém e que permanece estruturado por uma linguagem. Por isso, em nosso trabalho preferimos falar em imagem, objeto, e mesmo, significante, ou seja, a coisa material, de modo que não queremos falar de significado e sim de sentido, de interpretações, de possibilidade de projeção de representação.

${ }^{44}$ Romano, L. O teatro do corpo manifesto: teatro físico. São Paulo: Perspectiva/FAPESP, 2005.

${ }^{45}$ Artaud fala de uma "linguagem baseada em signos e não em palavras". Grotowski, por sua vez, busca a 'partitura' sendo esta um conjunto de signos corporais repetidos com precisão. O signo, para ele, se diferencia de uma gestualidade cotidiana, instaurando uma 'lógica da forma'. Neste sentido, aproxima-se das ideias de Meierhold, para quem o ator deve aprender a usar as convenções gestuais, construídas e codificadas. Segundo ele, o ator não poderá expressar-se de modo vago e involuntário, ou seja, deve se formar numa linguagem capaz de ser operada com precisão. No teatro do futuro de Craig, o ator ideal deve saber conceber símbolos perfeitos, de modo que sua marionete seria uma alternativa à imitação grosseira da realidade. As ações físicas de Stanislawski pretendiam domar as forças cotidianas do ator e, por meio delas, ele poderia determinar as formas e as emoções que definiriam a expressão do personagem, sendo necessária para isso a memorização e a codificação das ações. Assim, todos estes autores, encenadores e artistas estavam preocupados em desenvolver um trabalho técnico e de linguagem que pudesse domar o corpo cotidiano entregue à disposição do momento.

${ }^{46}$ Lucia Romano, op. cit.
} 
linguagem codificável e, portanto, comunicável - ainda que a finalidade não fosse a construção de um personagem a priori. Por meio de um corpo treinado e codificado os atores poderiam tanto dinamizar suas forças e irradiar sua presença, quanto ordenar suas formas e estruturar-se como linguagem que fala e age sobre o espectador.

\begin{abstract}
"As utopias que transformaram o corpo humano em máquinas biológicas eficientes, questionavam o teatro como forma de representação da realidade e inauguraram a ideia de cena enquanto escritura no espaço, que pode ser diretamente relacionada a uma 'Nova Dramaturgia', onde o movimento do corpo no espaço é central". 47
\end{abstract}

Diferentemente da abordagem psicologizada proveniente da tradição do teatro do texto falado, acreditamos que o trabalho do ator, ao atingir este aspecto técnico, produz formas $e$ mobiliza intensidades antes de identificar um personagem. Pois, ao enfatizar a composição e a organização estrutural do corpo, o artista poderia criar imagens que partem de sua substância puramente física "de modo a evidenciar uma corporeidade autossuficiente, em todas as suas potências gestuais" ${ }^{48}$. Nesta perspectiva, acreditamos que produzir formas não quer dizer necessariamente a construção de uma comunicação codificada, no sentido de que esta falaria uma linguagem, mas sim a exploração do corpo por meio de seu volume, traços, ângulos, peso e que podem compor uma imagem figurativa que não deseja, em princípio, ser signo.

\footnotetext{
"A tendência do corpo-material é que predomina hoje na prática geral da encenação, pelo menos no teatro experimental. É por essa razão que, depois de libertado da tarefa textual e psicológica, os encenadores da vanguarda tentaram frequentemente definir uma linguagem corporal do ator. (...) Todas têm em comum a busca de signos que não sejam calcados na linguagem, mas que encontrem uma dimensão figurativa." ${ }^{49}$
}

Se pensarmos a respeito da exploração material do corpo, isto parece ampliar as possibilidades expressivas do corpo em cena, de modo a não reduzi-lo como um suporte para a realização de um corpo conseqüente de uma determinação psicológica, nem a constituição de

\footnotetext{
${ }^{47}$ Idem, ibidem.

${ }^{48}$ Belloni, A. O Corpo e as coisas: a dissolução da fronteira entre o vivo e o não-vivo no contexto do teatro contemporâneo. Em Sala Preta, revista de artes cênicas da USP, São Paulo: 2008.

${ }^{49}$ Pavis. Dicionário, p.p. 167
} 
algo que quer dizer outra coisa, mas um corpo realizado por si e em si, que se apresenta como imagem dimensionada em suas formas. Assim como o encenador é um “criador de formas, um poeta da cena que escreve com gestos, ritmos (...) que fala aos olhos na mesma medida em que o texto se dirige aos ouvidos" ${ }^{50}$, o corpo do ator seria uma destas formas que está disposta em cena, que desenha o espaço com seus gestos, que imprime ritmos na cena, criando linhas, curvas e traços que vão compondo o espaço cênico. Visto sob este ângulo, o corpo não seria uma imagem imantada de signos que poderiam ser identificados pelo espectador.

\begin{abstract}
“(...) no lugar de uma figuração mimética ou de uma abstração simbólica, hoje se encontra, com freqüência, uma cena feita de uma sequência de imagens (...). A cena fica próxima de uma paisagem e de uma imagem mental, com se se tratasse de ultrapassar a imitação de uma coisa ou sua colocação em signo" 51
\end{abstract}

A imagem deste corpo poderia ser, portanto, mais um elemento da paisagem que se desenrola na cena, uma imagem sem referente e que é presença antes de tudo. Nesta perspectiva, ao ser composto pelo corpo - no corpo e a partir do corpo - esta imagem/corpo em cena parece ganhar dimensão de representável mais em função da relação que estabelece com os outros elementos da cena, ou mesmo, na situação em que está inserido, do que pela sua construção de códigos. Aqui poderíamos pensar na teatralidade que o espectador investe sobre a imagem/corpo disposta na cena, de modo que ele pode construir um discurso por meio de aglutinação, justaposição ou sobreposição que pode, neste processo, ser identificado e reconhecido como ser ficcional, ou mesmo se tornar conceito, ideia ou figura ${ }^{52}$.

Neste sentido, podemos nos recordar do predicado que Féral aplica ao teatro performativo, isto é, "um teatro centrado na imagem e na ação e não mais na representação." 53 Ou seja, a representação estaria relacionada mais pela sugestão das imagens e ações que

\footnotetext{
50 Picon-Vallin, B. A encenação: visão e imagens. Em, a arte do teatro: entre tradição e vanguarda. Org. Fátima Saadi. Rio de Janeiro: Teatro do Pequeno gesto/ Letra e imagem, 2006.

${ }^{51}$ Pavis, op. cit., p. 204.

52 Figura, segundo Pavis, seria uma forma imprecisa que significa mais por sua posição estrutural que por sua natureza interna. Figura aqui pode ser pensada como algo que não tem identidade própria. Podemos opor assim a ideia de figura à de personagem, na medida em que personagem traz o traço da identidade. Segundo Féral, personagem no âmbito do teatro performativo não pressupõe identidade.

${ }^{53}$ Féral, 2009, op. cit.
} 
presenciamos em cena e na sua disposição em relação aos outros elementos que a constitui, do que pela própria natureza da representação. Igualmente o corpo, visto em seu aspecto material e presente, poderia ser tanto mais uma sugestão do que a representação de algo. Assim, as imagens produzidas neste corpo - e por este corpo - podem servir de iscas que desencadeiam o processo imaginativo do espectador, fazendo com que ele participe ativamente da obra, criando seu próprio mundo imaginativo.

\title{
Corpo expressivo
}

Segundo Belloni (2008), o caráter da materialidade da composição convoca o espectador a "estacionar-se ante o sensível" de modo que, na evolução do trabalho do ator, que se afastou do caráter mimético, o corpo tomado pela sua densidade seria explorado mais pela sua capacidade expressiva.

\begin{abstract}
“Essa mudança do pólo da representação para o pólo da expressão fez com que o trabalho do ator passasse a ser considerado por seu caráter escultural, figural, corporal e performático." ${ }^{54}$
\end{abstract}

Deste polo expressivo ${ }^{55}$, pode-se dizer das investidas pulsionais ${ }^{56}$ e energéticascaracterísticas que acompanham as artes performáticas - e que parecem fazer sentido pela sua qualidade de não representável. Seria um aspecto táctil que emana do visível e que estaria ligado à presença viva e real do corpo do ator em cena. Esta relação presencial parece requerer uma participação real do espectador, de maneira que elepossa criar a obra junto com o artista,

\footnotetext{
${ }^{54}$ Belloni, op. cit.

55 Segundo Pavis, Lyotard distingue o discursivo do figural, sendo o primeiro pertencente à ordem do signo e da lingüística, enquanto o figural seria um acontecimento libidinal irredutível à linguagem. Por isso, acreditamos que estes aspectos destacados por Belloni, de um corpo expressivo que pode se apresentar como figura, pertence à ordem do figural.

56 Tomaremos o termo pulsional como derivado da pulsão (Trieb) que segundo Freud poderia ser definido como algo que se presta como broto, força germinativa, ou ainda, impulso, impulsão, propulsão e estaria ligada ao querer. A pulsão pode, portanto, ser compreendida como um processo dinâmico que impulsiona o organismo em direção a uma meta. A palavra Trieb na língua alemã pode ser usada em vários sentidos. Na linguagem corrente, o radical "trieb" e o verbo "treiben" são usados em referência a algo que impulsiona ou puxa alguém ou alguma coisa. "Trieb": "impulso interno que visa à satisfação de necessidades fortes e muitas vezes indispensáveis à vida". Dicionário Michaelis.
} 
por meio de uma comunicação que se estabelece para além do descritível e do identificável, que estaria mais próxima de afetividade ${ }^{57}$. Ou seja, uma comunicação ativada pelo corpo, pela sensação, pela sensualidade e que ataca os sentidos. Portanto, acreditamos que o corpo não seria mais um meio para uma finalidade, mas um corpo que mobiliza suas forças reais, instaurando-se como realidade. Isto seria possível, à medida que o teatro, como vimos, quer tocar na realidade e se promover como um evento que acontece aqui e agora, satisfazendo-se mais pela sua capacidade afetiva, do que pelo processo de representação.

Neste sentido nos remetemos a Lyotard ao propor um teatro energético questionando se seria possível ao teatro produzir a "(...) a mais alta intensidade (por excesso ou falta) do que está ali, sem intenção." ${ }^{58}$ Ou seja, um teatro que poderia extrair do corpo do artista cênico, e depois, do espectador, um campo de energia e de intensidade, uma vibração, um abalo físico. Mas pensamos também em Artaud e seu teatro da crueldade e da violência, que almejava um teatro do corpo e da pulsão, de deslocamentos e disjunção, um teatro não narrativo e não representacional.

"Tudo aquilo que pertence à ilegibilidade, à fascinação magnética dos sonhos, (...) estas camadas sombrias da consciência que são tudo que nos preocupa no espírito, nós queremos vê-las radiar no palco" ${ }^{59}$

Pavis, em seu livro $A$ análise dos espetáculos parece justificar que tais aspectos estariam na ordem do não representável, algo que seria desencadeado pela relação de um corpo a corpo com o espectador. Para tal, trata da energia que o corpo na cena irradia e que seria percebida pelo espectador - e consciente por parte do ator - e que permanece para além do descritível. Tal energia seria como sinais da atuação, ínfimos e quase imperceptíveis e muitas vezes ambíguos ou mesmo inelegíveis.

\footnotetext{
“O termo pouco científico e semiológico da energia é muito útil para enfocar o fenômeno não representável de que é questão aqui: o ator ou o dançarino emana, por sua
}

\footnotetext{
${ }^{57}$ Em seu ensaio intitulado Antonin Artaud: o ator e física dos afetos, Quilici dirá que o campo do ator é definido como campo de afeto, de modo que o desencadeamento das dinâmicas afetivas, no teatro de Artaud, dependeria de um trabalho físico e plástico. "O afeto designa uma espécie de poder de contágio da capacidade que o teatro teria de afetar." Sala Preta - revista de artes cênicas da USP. São Paulo: n. 5, 2005.

${ }^{58}$ Lyotard, J.-F. Le dent la paume, apud Pavis, op.cit.

${ }^{59}$ Artaud, A. Linguagem e Vida. São Paulo: Perspectiva, 2004.
} 
presença, seu movimento, seu fraseado, uma energia que atinge o chofre do espectador. Sentimos claramente que é essa qualidade que faz toda diferença e participa da experiência estética como um todo tanto quanto da elaboração do sentido. O não representável (...) procuramos identificá-lo (...) na audição, no ritmo, nas percepções sinestésicas, logo além dos sinais visuais" ${ }^{60}$

Acredita-se, portanto, que esta cena atual explora um corpo que se constitui para além de uma análise dos códigos, mas por sua qualidade de produzir sinais que podem ser percebidos num "corpo a corpo" entre espectador e ator. Sinais que podem ser sentidos pelo espectador, que escapam da ordem do representável e que seriam apreendidos pela sua expressão. Neste caso, aquele teatro de Lyotard, por desejar uma intensidade sem intenção, poderia ser pensado nesta ordem do não representável, isto é, daquilo que poderia ser percebido e sentido por afecção e não por mecanismos do pensamento, ou da visão, de modo que o corpo do ator poderia ser tomado mais por produzir uma intensidade do que por significar alguma coisa.

\section{Corpo e presença}

No mesmo entendimento, ao apresentar os signos teatrais que circunscrevem a cena pós-dramática, Lehmann elenca a corporeidade como um de seus componentes. Credita, então, à aura da presença corporal como sendo o lugar em que o significado se enfraquece, de modo que, quando damos ênfase ao potencial expressivo do corpo, o teatro se distancia do sentido. Assim, o corpo não se apresentaria mais como um portador de sentido, mas permaneceria ali à espera de denominação.

\footnotetext{
"Desse modo, opera-se um deslocamento no modo de ver a fatura dos signos em geral, quando no teatro pósdramático, se chega a uma extrema manifestação da corporeidade, que se impõe de um modo imediato e frequentemente assustador." 61
}

\footnotetext{
${ }^{60}$ Pavis. P. A análise dos espetáculos. São Paulo: Perspectiva, 2003.

${ }^{61}$ Lehmann, op. cit.
} 
Este aspecto de imediato parece ecoar no caráter da presença deste corpo, que está ali, antes de tudo e que faz com que percebemos a cena em seu aspecto real e eventual, como algo que acontece naquele momento. Este corpo estabeleceria, assim, o cerne da situação teatral: a copresença do ator vivo, ou melhor, a presença humana entregue ao olhar do público, isto porque "o teatro é realizado aqui e agora", no organismo dos atores, diante de outros homens" 63 . O corpo do ator, então, passa a ser um lugar de exploração, uma realidade autônoma que não narra mediante gestos uma situação específica, mas se manifesta, antes, como presença: em primeira instância seu corpo é seu corpo e está presente em cena com sua realidade vulnerável, brutal, erótica, ou sagrada ${ }^{64}$. Nesta perspectiva, o corpo do ator, antes de tudo, está presente em cena, é irrevogável, existe e é concreto. Sua presença no palco parece oferecer aos nossos corpos e aos nossos ouvidos a sensação de que ele está ali, no mesmo espaço e no mesmo tempo o qual nos encontramos. Neste sentido, Pavis (2003) reforça que o primeiro trabalho do ator seria o de estar presente, de se situar aqui e agora para o público, ao vivo e sem intermediários.

Além disto, este corpo, explorado em seu aspecto energético, irradia tensões e vibrações que tocam o espectador - por isso a dimensão táctil de sua presença: o espectador sente seus impulsos ${ }^{65}$. Assim, sugerimos o distanciamento do corpo como signo à medida que exploramos cada vez mais uma cena que não querer esconder o corpo do ator atrás de signos que determinariam uma unidade ficcional. Ao contrário, vemos o corpo do ator ser imantado

\footnotetext{
${ }^{62}$ Neste sentido, corpo e presença aderem-se ao acontecimento, por meio da tomada de consciência da realidade vivida pelo público.

${ }^{63}$ Grotowski, J. Em busca de um teatro pobre. Rio de Janeiro: Civilização Brasileira, 1987.

${ }^{64}$ Lehmann, op. cit.

${ }^{65}$ Grotowski refere-se aos impulsos como algo que precede, imediatamente, as ações: "É como se a ação física, ainda invisível do externo, tivesse já nascido no corpo. É isso o impulso. Antes da ação física, tem o impulso, que empurra de dentro do corpo (...). A ação física, se não inicia de um impulso, vira algo de convencional (...). Quando trabalhamos com o impulso, ela [a ação] fica enraizada". Apud Ferracini, R. A arte de não interpretar como poesia corpórea do ator. Campinas: Ed. Unicamp, 2003. Podemos consideram esta noção como algo que é produzido no corpo que está latente e pode ser sentido. Tal definição parece ainda reverberar na definição de pulsão que apresentamos anteriormente.
} 
de presença de modo que suas forças libidinais ${ }^{66}$ sejam expressas por parte do ator e percebidas pelo espectador.

Poderíamos dizer, assim, que este corpo que quer se apresentar em cena como corpo parece creditar uma comunicação na sua capacidade de irradiação. Isto é, de poder gerar algo que parte de sua presença, criando textura na cena por meio de suas intensidades e tensões. Deste modo, parece-nos que, mais uma vez, poderíamos falar de uma corporeidade autossuficiente, que não seria traduzida em cena por uma retórica, uma narrativa ou uma lógica, mas por ser um corpo que apela à própria expressividade de sua matéria.

Acreditamos que ao falar de um corpo codificado, correríamos o risco de permanecer na esfera da linguagem, remetendo-nos a códigos e convenções reconhecíveis culturalmente. No entanto, parece que o corpo pode ser tomado na cena por qualidades que não são reconhecíveis e que portam certo grau de "autorreferencialidade" porque permanecem na esfera da "presentação" enfatizada por sua exploração material.

“O prevalecer da esfera da presentação geraria
resultados que ultrapassariam a ilustração de
situações e circunstância, para colocar em evidência a
corporeidade e suas qualidades expressivas." 67

Novamente, falar de qualidades expressivas parece recorrer ao aspecto da presentação, ou seja, da presença de um corpo que estaria irrevogavelmente em cena e que irradia sinais (expressividade), de modo que tanto o corpo quanto a expressividade não pretendem ser significados. Eles seriam percebidos pela sua presença real. A expressividade, a corporeidade, a presença viva do artista parecem nos aproximar da ordem da presença, já destacada por Fischer-Lichte (2007), mas também aquela sugerida por Pavis (2003) de não representável e ainda, às intensidades geradas pelo/no corpo como sugere Lyotard (1994). Este espectro parece validar o corpo do ator como um vetor que puxa a cena teatral para a ordem do real e dá voz aos fluxos energéticos que se expressam na superfície deste corpo. Pode-se assim chegar ao fato de que o corpo do ator em cena é antes de tudo real e está presente, e pode ser tomado por sua capacidade de se expressar, antes de se extrair dele algum sentido.

\footnotetext{
${ }^{66}$ Libido do latim significa desejo ou anseio. Na psicanálise pode ser tratado como força ou energia psíquica por trás da ação humana. Um sinônimo possível seria sensual, ou seja, algo concernente ao sentido.

${ }^{67}$ Matteo Bonfitto. “Do texto ao contexto”. Em Humanidades. Brasília: Universidade de Brasília, 2006, p. 48
} 
E com isso, acreditamos que seria possível falar de um corpo expressivo e não um corpo que significa, um corpo que não pretende dizer, diretamente, isto significa aquilo, mas um corpo que pode sugerir que isto pode ser aquilo, mas também pode não ser, de maneira que não estaria em seu objetivo dizer algo, mas ser tomado como um possível. Assim, podemos creditar à teatralidade sua potência de gerar um processo de ficcionalização, ou seja, de jogar este corpo de presença para um lugar imaginário. No entanto, consideramos que algumas partes permaneceriam à espera, e por lá ficariam. Falamos de uma comunicação que se opera na ordem da assimilação simpática, isto é, "pela excitação sensível provocada pela forma tangível da realidade física." 68

\section{Corpo e performance}

Diante disto, levamos em consideração as projeções de Féral e Lehmann quando tratam de certos aspectos da performance que foram absorvidos pelo teatro. Em seu ensaio intitulado Performance et théâtralité: le sujet démystifié, a autora faz a primeira consideração na qual trata da manipulação corpo do artista: "o performer trabalha com seu corpo como o pintor com a tela" ${ }^{69}$. Isto significa dizer que o corpo, neste caso, seria o suporte principal que o artista performático poderia manipular, explorar, recortar, tingir aderindo-se, enfim, à sua realidade. Podemos nos remeter à ordem do real, isto é, um corpo que enfatiza sua própria realidade, que não se esconde atrás de nenhum anteparo: seu corpo é corpo e se recusa a qualquer ilusão. Poderíamos dizer ainda, que o corpo do performer passou a ser um lugar ideal no qual o artista iniciou sua caminhada em direção ao não representável. Pois ele não precisa de nenhum elemento externo, não prescinde de nenhum objeto, não depende de nada que faça uma mediação com o observador, ele encerra, em si mesmo, a própria obra ${ }^{70}$. Ora, por mais que tentemos escondê-lo por trás de diversos artifícios, seu corpo estará diante do espectador que, inevitavelmente, percebe-o enquanto realidade.

\footnotetext{
${ }^{68}$ Tereza Rocha, apud, Romano. op. cit.

${ }^{69}$ Féral, 1984.

70 Não descartamos aqui o uso das tecnologias e dos suportes que acompanham determinadas práticas performáticas, pois estamos tratando desta arte em relação ao próprio corpo do artista.
} 
Ao aproximar o teatro da arte da performance, Lehmann (2003) sublinha que seria possível compreender o teatro pós-dramático "como uma tentativa de conceitualizar a arte no sentido de propor não uma representação, mas uma experiência do real" ${ }^{71}$. Esta experiência real seria a experiência imediata que público e artista compartilham. Logo, vemos novamente o real aderindo ao teatro, não somente em seu aspecto material, mas também em seu aspecto relacional, espacial e temporal. E, novamente, o corpo do artista está ali disposto a compartilhar este evento com o espectador. Lehmann leva em consideração ainda, que tanto em seu teatro quanto nas práticas performáticas, o que estaria em primeiro plano não seria a representação de um personagem, mas "a vividez, a presença provocante do homem". Ou seja, a produção da presença, a intensidade de uma comunicação corpo a corpo são elementos da arte da performance que podemos observar nas investidas do corpo do ator nesta cena atual. Percebe-se com isso, que o ator que anexa aos seus procedimentos os princípios da performance se coloca em cena presente, antes mesmo de querer ser tomado por algum sentido $^{72}$. Assim, podemos falar, em primeira instância, que o performer não está ali preocupado em atuar, ele está apenas oferecendo à contemplação sua presença no palco. Neste momento, ele não quer informar nada a respeito de sua atividade.

Segundo Romano (2005), o aspecto do evento performático absorvido pelo teatro imprime ao espetáculo um tipo de "presentidade" fora do alcance do imaginário (ficção) e do simbólico (a linguagem), acessível na relação entre o corpo do ator e do espectador. No entanto, no artigo supracitado, Féral propõe que a teatralidade poderia ser compreendida como um resultado das forças entre duas realidades coexistentes no teatro, ou seja, as estruturas simbólicas específicas da arte do teatro e os fluxos energéticos provenientes da arte da performance.

As considerações de Renato Cohen (1992) a respeito da performance parecem ir na mesma direção. O autor ao considerar o contexto artístico em que o performer está inserido, aponta, para um campo ficcional, metafórico, que se reveste de significação (campo da teatralidade); entretanto, considera que seu suporte está relacionado com o momento

\footnotetext{
${ }^{71}$ Lehmann, op. cit.

${ }^{72}$ Silva, S. A. (org.) J. Guinsburg: Diálogos sobre teatro São Paulo: EDUSP, 2002.
} 
presente, com suas interações corporais, psíquicas e intelectuais ${ }^{73}$ (campo da performance). Tratar o ator como performer significa dizer que sua presença não estaria vinculada à representação mimética de um papel, mas antes, concentrada em uma atitude na qual ele se propõe a completar a ação, a participar do processo e colocar seu corpo como material para o sentido. Ele não finge ser outro, ele não se encarrega de mimar um indivíduo completo e uno, não é mais simulador. Ele, antes, realiza ações reais como ele mesmo: dinamiza o jogo, coloca em cena suas ideias, apresenta suas falhas, deixa lacunas, enfim se presta a sua subjetividade. Pois a performance solicita a manifestação do corpo do artista e de seu engajamento na atividade em que está desempenhando, de modo que ele mobiliza seus princípios afetivos, assume seu comportamento e leva em consideração as características que o definem: seu corpo, sua fala, suas ações lhe são próprias $^{74}$. Esse é um dado que nos direciona ao princípio sugerido por Féral, em que o teatro performativo toca na subjetividade do performer.

Assim, o corpo não seria somente material e fisiológico, objeto e suporte. Ele tomado como corpo vivo pode ser visto como imagem, mas também exala odores, cospe, sua e ainda produz forças físicas. Lehmann (2007) parece definir com precisão este corpo vivo como "uma complexa rede de pulsões, intensidades, rede, pontos de energia e de fluxos no qual processos sensório-motores coexistem com lembranças corporais acumuladas, codificações e choques". ${ }^{75}$ O que o autor parece levar nota para um corpo vivo nos remete novamente ao teatro energético, ou mesmo, ao teatro de Artaud, que parece querer evidenciar justamente tais aspectos do corpo, deixando-os irradiar na cena. No entanto, Lehmann acrescenta que o corpo carrega consigo traços que foram se desenhando ao longo de sua vida. Isto parece ir em direção oposta àquela ideia de um trabalho técnico e rigoroso, de autoeducação e de aprendizagens técnicas. Mas, acreditamos que este princípio só vem a acrescentar uma atitude expressiva. Pois este corpo que se educa quer conhecer suas formas, suas limitações, o ambiente em que foi formado, já que as técnicas do ator contemporâneo não se definem somente por um aprendizado técnico, ou seja, uma educação formalizada, mas também

\footnotetext{
${ }^{73}$ Cohem, R. e Guinsburg, J. Do Teatro à Performance: Aspectos da Significação da Cena. Em Armando Sérgio da Silva (org.), Diálogos Sobre o Teatro, São Paulo: Edusp, 1992, p. 226.

${ }^{74}$ Pavis, op. cit.

${ }^{75}$ Lehmann, op. cit.
} 
potencializam as descobertas individuais do próprio artista em seu processo de trabalho e treinamento. $^{76}$

Para Féral, o corpo do performer é $u m^{77}$ "corpo parcelar, fragmentado, e, portanto, um corpo percebido e rendido como lugar de desejo, de deslocamento, de flutuação(...)" $)^{78}$ que, somados aos aspectos destacados por Lehmann, conduz aos debates contemporâneos em que o corpo passa a ser tratado não como uma unidade funcional, mas como o próprio lugar da falta ${ }^{79}$.

Em princípio, imagina-se que o que determina sua condição de estar em cena refere-se ao seu corpo dito fenomenal. Isto é, um ser-no-mundo que lhe é particular, tomado por suas características físicas $^{80}$. Explora seus comportamentos próprios que derivam da plasticidade de seu corpo, um modo singular ligado ao ritmo, ao tamanho de seus passos, à extensão de seus movimentos. Mas a este corpo podemos somar seu modo de pensar, de se expressar, de mirar. Pois ele também é sugestionado por suas memórias, suas lembranças, definido e redefinido a todo instante por suas experiências múltiplas. Suas características não são apenas fisiológicas e natas, sua superfície é imantada de signos sociais, culturais e histórias pessoais. Afinal, tudo que fizemos, nossas histórias, nossa ideologia, o discurso do outro, fazem parte da nossa vida e marcam o nosso corpo. Para além de sua materialidade, sugerimos que ele possa ser pensado como organismo vivo, que percebe e vive a realidade da cena.

Se a performance sugere um corpo como meio de exploração, passagem de fluxos, espaço de experiência, zona de desejo ${ }^{81}$, ele pode ser pensado para além da matéria, ou seja, como um processo que é constituído a todo o momento. Ele seria formado em sua

\footnotetext{
${ }^{76}$ Romano. Op. Cit.

77 Grifamos o termo para estar de acordo com o princípio deste corpo que quer deixar de ser pensado como unidade biológica.

78 Idem, ibdem.

79 O corpo como espaço de desejo é tratado por Guatarri e Deleuze em "Como criar para si um corpo sem órgãos". $\mathrm{Na}$ ocasião tratam este corpo como um campo de imanência do desejo, um plano de consistência própria do desejo ali onde o desejo se define como processo de produção, sem referência a qualquer instância exterior [...]. Este corpo não é suporte para elaboração psíquica de desejo, ele mesmo manifesta seu desejo, é ele quem quer, e não nossa consciência. Desejo para os autores pode ser referenciado à falta, de modo que o corpo, na falta, carece de necessidades.

80 "Como signo corporal, por exemplo, o peso do corpo pode comunicar seu poder, mas o que predomina é a impressão sensorial crua, destituída de qualquer interpretação". Fischer-Litche (2007)

${ }^{81}$ Féral. op. cit.
} 
complexidade de relações que estabelece consigo mesmo, com os outros, com o mundo em relações que experimenta prazer e desprazer, alegria e dor, medo ou confiança, de maneira que aquilo que é vivido, o é em todas as instâncias ${ }^{82}$. O gestual do sujeito, por exemplo, não é puro, nato, ele muda o tempo todo, os gestos do outro vão compondo o meu gesto: um corpo percebe o gesto do outro e redimensiona-o segundo suas próprias estruturas físicas e contexto cultural em que está inserido.

Seria neste sentido que o corpo biológico desaparece e abre espaço para se tornar um produto socialmente construído e infinitamente maleável ${ }^{83}$. Igualmente, o corpo na cena está em constante processo, de forma que a ideia da estrita reprodução de algo pelo corpo do ator na cena parece se tornar cada vez mais frágil: o que aconteceu ontem em cena gera interferência no físico e no pensamento do ator, sendo que isto acarretará amanhã outras proposições. Como o corpo é acionado pela subjetividade, o indivíduo se abala para o dia seguinte e, no mesmo sentido, a cena tomada por sua realidade que se apresenta em contato direto com o público mobiliza corpos reais, colocando-os em situações reais, e neste momento o ator vive a experiência da situação que, embora tenha sido organizada anteriormente, é tensionada e amplificada pela relação do aqui/agora que é a realidade da cena teatral.

Estes aspectos do corpo nos direcionam, novamente, ao princípio do real, de modo que o ator está disposto a agir em dado espaço e tempo, além de se manter em potência de ser algo: público e artista estão dispostos a experimentar outros mundos possíveis. 0 ator/performer não se impõe como detentor de uma verdade moral, mas se dispõe a ser algo que aciona os processos perceptivos, sensíveis e imaginativos tanto do público, quanto dele próprio e, ainda, dos outros que com ele compartilham a cena.

\footnotetext{
${ }^{82}$ Santaella, I. Corpo e comunicação. São Paulo: Paulus, 2006.

${ }^{83}$ O corpo, segundo Santaella é fenômeno histórico: suas propriedades de andar, sorrir, cavar, nadar, não são naturais, mas conquistas técnicas. "Tanto quanto o sujeito, ele [o corpo] não passa de uma variável em modificação contínua e aberta.
} 
Na amplitude de sua relação com o público ele é capaz de abalar a percepção do espectador, de modo que ele afeta e é afetado pelo público ${ }^{84}$ : logo, ele pode ser explorado como agente provocador de uma experiência sensível. Sob esta perspectiva, o corpo se presta menos à informação, pois não pretende, previamente, fornecer dados para uma leitura, ele está presente e sua irradiação possibilita uma comunicação afetiva. Esta, se faz por contágio, pois o corpo presente pretende estabelecer um contato direto com o público e conduzir, assim, sua relação com a obra ${ }^{85}$, numa espécie de fusão.

Se o espectador pode olhar para este corpo como ele é, isso ocorre porque ele se deixa observar pelo que existe, que acontece, pelo que se dá a conhecer. O corpo neste contexto poderia ser pensado como provocador, estimulador porque não dá respostas, mas infere o público a refletir sobre as possibilidades de respostas que podem vir a fazer sentido por meio de suas atitudes: o observador percebe, vive e interpreta aquela existência.

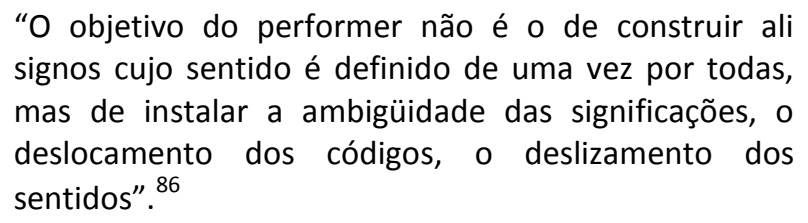

\section{Corpo em ação}

O que vemos o ator fazendo em uma cena de predominância performática, ou mesmo em uma perspectiva pós-dramática, ou seja, em uma cena em que as ações não têm como finalidade a determinar o caráter do personagem? O que percebemos diante da cena que evidencia um corpo em expressão? No que tange a procedimentos que desencadeariam tal

\footnotetext{
${ }^{84}$ Ferracini denomina Zona de Turbulência à relação instaurada no espaço cênico entre espectador e ator. Uma circunstância em que o artista afeta o público e é por ele afetado. Tal acepção parece ir ao encontro à projetada por Fischer-Litche (2008), na qual encenação se dá no momento presente da cena, e que tanto espectadores quanto atores participam, pelo fato de ambos modificarem a cena. Para a autora, os atores reagem a qualquer tipo de "resposta" do espectador, o que abala a estrutura préfixada pelo encenador.

${ }^{85}$ Lehmann problematiza a questão da presença à medida que considera as pessoas como sendo ao mesmo tempo uma infinidade de possibilidades diferentes: a presença é tomada como um possível, um devir, mas também, como uma ilusão de uma possível presença plena. (2007).

${ }^{86}$ Féral, 2008. op. cit.
} 
expressividade, poderíamos nos remeter à noção de ação física, tomando-a como o catalisador das forças internas e orgânicas do corpo ${ }^{87}$.

Em termos do que se vê em cena, diríamos que os atores agem, executam ações sem que suas atividades estejam ligadas a um sentido determinado. Ou seja, seus movimentos, gestual, modo de olhar, poses, deslocamentos, enfim, suas atividades diversas adquirem sentido em meio à paisagem material, não sendo determinadas por um motivo. Isto porque estamos considerando-o como mais um elemento em meio à luz, ao som, ao cenário, aos objetos. Eles não estariam mais em um lugar de produção de sentido a priori. E, como não há mais um personagem a reproduzir, nós podemos sugerir junto a Artaud que o ator não representa, mas age. Entendemos que é neste sentido que Féral destaca a realização da ação como uma das características que define seu eatro performativo ${ }^{88}$.

Para retirar esta premissa, Féral retoma as operações que Schechner realiza para definir o que estaria pressuposto no ato de performar, isto é, o ser, o fazer e o mostrar fazendo verbos que representam ação e que segundo a professora estariam em jogo em qualquer ato de performar. Ao associá-los aos conceitos de verbo performativo traçados por Austin e Searle, verbos que realizam uma ação, a pesquisadora canadense dirá que a noção de performativo valoriza a ação em si , mais do que seu caráter representativo, no sentido mimético. Sugere, assim, na perspectiva do teatro performativo, a primazia do fazer, enquanto atividade de qualquer coisa existente, em relação à elaboração de um significado ou um sentido que acompanha as ações quando projetadas em um teatro visto sob o aspecto tradicional.

\footnotetext{
"Quando Schechner menciona a execução de uma ação na noção de performar ele na realidade não faz senão insistir neste ponto nevrálgico de toda performance cênica: o fazer" (2008)
}

Neste sentido, fazer, executar uma ação estaria se opondo à presença de um corpo que deveria permanecer escondido e condicionado a uma ficção, que em sua forma gestual estaria

\footnotetext{
${ }^{87}$ Os aspectos em relação aos procedimentos serão abordados na parte seguinte, na qual tratamos do trabalho desenvolvido pela Cia. de Teatro em Quadrinhos.

${ }^{88}$ Féral, a partir desta consideração, traz duas noções que estariam pressupostas em relação à execução da ação. A primeira, que é a qual nos referimos, diz respeito à atividade do ator em cena. A segunda, a autora a relaciona ao caráter de eventualidade, do princípio do ato enquanto aquilo que acontece naquele momento.
} 
a serviço de um ente fictício e que deveria se mover conforme um referente. Ao contrário disto, a atenção do espectador estaria centrada na execução do gesto, na criação das formas, na diluição dos sinais e sua permanente reconstrução. Os atores podem assim, cantar, dançar, falar, colocar uma máscara, mostrar um personagem, subir na rede. Este conjunto de atividades poderia ser considerado como ações executadas em cena. Tais ações, por sua vez, constituem imagens que o espectador observa e pelas quais se deixa levar. Pode-se sugerir que suas ações são performativas porque por não se caracterizarem por uma linearidade, parecem estar sempre reiniciando uma nova cadeia de sentidos, modificando a própria realidade da cena. E sem se preocupar em procurar o significado da imagem, o espectador se deixa levar por esta performatividade em ação.

\footnotetext{
"Os arabescos do ator, a elasticidade de seus corpos, a sinuosidade das formas que solicitam o olhar do espectador em primeiro plano, estão no domínio do desempenho." ${ }^{\prime 89}$
}

Em convergência aos princípios da performance, são seus corpos, os jogos e suas competências técnicas que estão em primeiro plano, ou seja, no plano do fazer alguma atividade segundo suas próprias habilidades. Diante desta configuração de ações que não querem, a princípio, ser reduzidas a um significado e que estão diante do espectador sem finalidade moral ou causal, ele é quem pode projetar um sentido. Portanto, deduz-se que, se a performatividade quer ser a ação em si, uma ação que não tem pretensão de ser outra coisa do que aquilo que se movimenta no espaço, em contrapartida, seríamos conduzidos ao campo da teatralidade porque o espectador completa, em um segundo momento, os sentidos que podem emergir daquele conjunto. Acrescenta-se, ainda, que este estado de performatividade em que o ator se encontra seria o que veicula a possibilidade de sentidos que vão sendo gerados ao longo da obra. Isto porque os sentidos produzidos são acionados conforme aparecem novas realidades cênicas. Ora, se o ator permanecesse executando suas ações sempre em um mesmo plano e segundo o mesmo princípio, os sentidos não seriam fluidos ou contraditórios, seriam reconhecidos e permanentes.

\footnotetext{
${ }^{89}$ Féral, 2008, op.cit.
} 
Na mesma direção, Schechner sugere atores que se movimentam quase como na vida, no entanto, com certa obliquidade em seus traços. Acrescenta que isto acontece porque há em seus gestos algo diferente, como fratura, alienação, abertura ${ }^{90}$. As características que o diretor norte-americano imprime nestes gestos parecem esbarrar na descontinuidade e oscilação que operam na performatividade. Ora, se a narrativa exposta em cena é cheia de buracos, espaços abertos, ausências e contradições; se nossa realidade agora é um passado cheio de buracos, um presente estimado e um futuro desconhecido, similarmente, temos em cena atores ditados pela fratura, alienação, abertura, e que exploram ao máximo suas pulsões, delírios e inoperâncias.

O ator é fraturado, porque pode ser alguma coisa agora, e em seguida, ser outra; alienado, porque pode estar ali sem identidade, alheio a tudo que está ao seu redor e se apresentar apenas como uma imagem que caiu de paraquedas; aberto, porque se desdobra em muitos, porque pode entrar e sair do personagem, porque pode ocupar os buracos sem cumprir função dramática. Esta oscilação distorce a força dramática e abre espaço para alguma coisa que escapa à representação, porque promove, justamente, uma desconstrução no logos. E, ainda que possamos vislumbrar a máscara do personagem, naquele contexto, nossos olhos permanecem atentos à conjugação das formas, aos movimentos dos seus corpos, às expressões de suas marcas, de forma que tudo isto se apresenta como algo que não é nem ele, nem outro (personagem), nem alguma outra coisa: a coisa está a todo o momento em condição de se tornar outra coisa.

Recorre-se ao princípio do gesto que Lehmann (2007) apresenta ao tratar das imagens corporais pós-dramáticas $^{91}$, que ele divide como dança, o gesto, escultura, corpo-força, corpo e as coisas, corpo estético versus corpo real, corpo infernal, corpo decadente, entre outras. Interessou-nos a proximidade do gestual da dança, uma vez que a dança ${ }^{92}$ não pretende formular um sentido, e sim, articular energia, visando ao compartilhamento emocional do

\footnotetext{
${ }^{90}$ Schechner, 2001, op. cit.

${ }^{91}$ Lehmann, op. cit.

92 Lehmann está falando, neste caso específico, da dança que na sua evolução "partiu do campo semântico [dança clássica] para o sintático [dança moderna] e então par ao pragmático [pós-moderna]" atendo-se, portanto, a esta última categoria.
} 
impulso. Pois a dança, segundo o autor, distancia-se de uma representação ilustrativa e age: tudo nela é gesto. Isto parece novamente alcançar o potencial de uma comunicação afetiva desencadeada pela impressão de movimentos. Gestos sem finalidade, gestos de intensidade. Gestos que são ações produzidas pelo corpo e que se constituem como imagens móveis que orientam o olhar do espectador e ao mesmo tempo provocam uma cadeia de fluxo energético: “No lugar do drama como meio da complexa e simbólica representação de conflitos, encontrase a vertigem corporal dos gestos" ${ }^{\prime 93}$

Em outro apontamento em relação ao gesto, o autor traz definições de gestos em Giorgio Agamben e Walter Benjamin, que nos parecem sincrônicas com a performatividade da atuação. Lehmann trata da perda da linguagem gestual que, para Agamben, na modernidade se tornou um meio sem finalidade: “O gesto consiste em exibir uma medialidade, em tornar visível um meio para tal" ${ }^{94}$.

Os gestos dos atores, quando tratados como imagem, no teatro pós-dramático, adquirem força justamente por não prescindirem do caráter de finalidade, o que sugere preservar a autonomia em relação a um referente, constituindo-se apenas como meios que desencadeiam processos imaginativos e afetivos. Na mesma linha segue Benjamin para quem, nas palavras de Lehmann, o corpo em seu modo de ser gestual manifesta uma dimensão em que tudo permanece como potência no ato, um meio puro. Característica presente, também, no teatro performativo ${ }^{95}$, onde o que se vê permanece em constante estado de adquirir um sentido, mas que a todo tempo permanece sendo algo em si.

Poderíamos concordar com Lehmann, quando defende que o corpo no teatro pósdramático é um corpo de gesto, de modo que o gesto seria aquilo que permanece em suspensão na ação de um objetivo: correr, andar, pular, saltar, ou mesmo, levantar a mão, entrelaçar-se com o outro, olhar para cima seriam o objetivo da ação do ator (realizar uma atividade). Mas este objetivo não pretende definir a situação em que se encontram. $\mathrm{O}$ que emerge de suas atividades seria a dinamização real do espaço, do tempo e do corpo como uma

\footnotetext{
${ }^{93}$ Lehmann, op.cit.

${ }^{94}$ Giogio Agamben, Noten zur Gest. Apud Lehmann, Op. Cit.

${ }^{95}$ Apresentamos estas características no capítulo anterior.
} 
força vibratória e convulsiva que permanece impressa na cena. Uma força produzida pela imagem do sujeito em ação. O que parece vincular o gesto do corpo às tensões corporais nele produzidas e que se expressam sem que a finalidade seja a produção de uma tensão dramática. Ação, pensada neste âmbito, não seria, portanto, um encadeamento lógico, a ilustração de uma fábula contada por um texto, a determinação do caráter de um personagem, mas algo que estivesse em potência de tornar-se algo. Similarmente, o corpo agindo não estaria condicionado a ser uma sequência de movimentos lógicos com função na engrenagem teatral, mas um catalisador das forças dinâmicas da cena.

As qualidades aferidas por Lehmann a respeito da atitude do corpo em gesto parecem, neste caso, fazer mais sentido do que qualquer tentativa de enquadrar a ação dos atores dentro de uma finalidade. Isto porque, caracterizada como atitudes gestuais, há algo que permanece em suspensão, o que parece ir em direção ao que Schechner propõe - aquela atitude fraturada, alienada, aberta.

Assim, terá execuções de ações, como uma atividade que ganha dimensão na própria composição da cena. Ações que podem ser sobrepostas, coladas e ininterruptas que interferem na cinética da encenação e se destinam ao olhar perceptivo e ativo do espectador. Existe ainda, a possibilidade de atores que agem de modo a transitar pela cena ora como imagens, ora como máscaras, ora como contra-regras, que podem ser um, ou mil personagens, que podem ser apenas uma fala, isto é, que desempenham atividades diversas em uma mesma encenação, dependendo da estrutura narrativa operada pela cena. Mas também há ações que passaram a ser um vetor para uma comunicação visual e táctil, na sua capacidade de produzir forças e intensidades na cena. Os indivíduos podem fazer muitas coisas, seus gestos tendem a ser imprevisíveis e ofuscantes e a narrativa não se destina a uma realidade fechada. Ação, assim, pode ser uma imagem cinética desenvolvida pelo corpo e percebida em seu estado fenomenal. Isto é, percebida pela aparente forma que o corpo assume e que está em movimento. E que pode afetar o espectador pela sua capacidade de produzir intensidade vibratória, com força para agir sobre sua sensibilidade. ${ }^{96}$

\footnotetext{
${ }^{96}$ Sensibilidade como a capacidade que temos de sentir não só emoções, mas dor, prazer, terror, calor, frio, aversão, medo, tremor, etc.
} 
Ao contrário do teatro da fala - que era o lugar da produção de sentido dramático - o teatro que tem o corpo como base para sua constituição parece querer oferecer outros modos de percepção que não passam, necessariamente, pelo logos. O corpo como materialidade explorada parece querer fazer oposição a uma realidade mental inteligível. Se ele pode ser uma imagem, uma voz, um vulto, parece-nos que ele quer ir em direção aos sentidos e explorar uma experiência de sensações físicas, direta, sem intermediação do pensamento - da palavra que pretende determinar o conhecimento. Ele parece querer dizer "eu sinto", e não "eu penso". O corpo do ator se impõe nesta conjuntura sobre a matéria ilusionista, de modo que ele tem uma participação real-corporal, tornando-se um "testemunho sensorial da existência das coisas" ${ }^{97}$. A ênfase na presença de um corpo que age pode produzir efeitos sobre o espectador, antes mesmo que o ator tenha tomado a palavra.

Tratar este corpo como significante ${ }^{98}$ seria, ainda, concebê-lo em uma atitude performática, ou seja, como um instrumento capaz de agir em direção a perturbar e interromper toda a significação que provenha da estrutura, da dramaturgia e do discurso. No que tange à teatralidade, que processa o espaço da construção ficcional, o corpo do ator pode ser apresentado como um material de significação, pois aciona o processo de produção de teatralidade, para que o espectador mantenha uma relação ativa e produtiva com a obra, acionando seus processos ficcionais. Vale lembrar que isto não impede que estes corpos sejam percebidos sem que qualquer sentido seja construído. E nesta conjuntura

\footnotetext{
"O teatro performativo toca na subjetividade do performer. Para além dos personagens evocados, ele impõe o diálogo dos corpos, dos gestos e toca na densidade da matéria." ${ }^{99}$
}

Toda esta corrente do teatro que quis abafar a supremacia da fala parece ter recorrido ao corpo como suporte para a criação cênica.

\footnotetext{
97 Lehmann, op. cit.

${ }^{98} \mathrm{Em}$ conformidade ao pensamento do corpo como imagem material que não quer atingir seu estado de signo. Em seu aspecto material podemos pensar em significante, isto é, manter o corpo no campo da expressão. "No teatro, o plano do significante (da expressão) é constituído por materiais cênicos (um objeto, uma forma, uma luz, uma mímica, um movimento, etc.), ao passo que o plano do significado é o conceito, a representação ou a significação que veiculamos ao significante." Pavis, op. cit.

${ }^{99}$ Féral, J. 2008. Idem.
} 


\section{PARTE III - CIA E CENA: Cia. de Teatro em Quadrinhos}

O pensamento que não se transforma em ação envenena a alma.

H. Müller

\section{A encenadora}

Encenadora, pesquisadora e professora de interpretação teatral do Dep. de Artes Cênicas da Universidade de São Paulo, Beth Lopes iniciou seu percurso artístico ainda em Santa Maria/RS, cidade em que nasceu e onde se fez sua formação em artes cênicas. Para dar continuidade à sua formação, freqüentou o curso de mímica com alunos de Decroux, na Ècole de Momodrame, em Paris; treinamento corporal com Pagneux; bufão e Clown com Gaulier; consciência corporal com Klauss Vianna e antropologia teatral com atores do Odin Teatret. Em São Paulo: sua primeira incursão artística na cidade foi com o grupo de Arte Boi Voador. Funda, então, a Cia. de Teatro em Quadrinhos, um núcleo que se formou a partir de seu grupo anterior. Atualmente, a pesquisadora se encontra em New York e desenvolve seu projeto de pós-doutorado sobre Performance, com Richard Schechner.

Seu currículo como encenadora soma inúmeras produções artísticas, das quais destacamos algumas que causaram impacto na cena teatral paulista: À Margem da vida, de Tennessee Williams; Os Brutos também amam, de Luiz Cabral; Violetta Vita, também de Cabral; No olho da rua - reunião de 20 histórias sobre a cidade, com texto de Cabral e Ricardo Soares; Silêncio, de Peter Handke; O jantar e Bis, ambos de Cabral; Piratas do Tietê, com texto de Rogério Lopes para os quadrinhos de Laerte (Com a Cia. La Mínima); Quatro estações, que reuniu texto de quatro autores: Marçal Aquino, Luiz Cabral, Dora Castellar e Ricardo Soares, cada um foi escrito para cada estação do ano. Mas foi com O Cobrador, inspirado em Rubens Fonseca que a diretora ganhou projeção na cena brasileira pelo impacto visual de sua produção e pelo trabalho vigoroso que apela para os códigos dos quadrinhos traduzidos no corpo dos atores.

Nota-se uma convergência em suas encenações quanto ao trabalho técnico corporal que a pesquisadora desenvolve em suas experimentações o que poderíamos chamar de "tradução corporal do drama", em que as ações físicas entrelaçadas à narrativa textual 
fundamentam o trabalho artístico. Em seus espetáculos, percebe-se forte visualidade que conta com a utilização de uma narrativa cênica composta por dança, luz, cor, movimentos, luz, figurinos. Textos, sejam eles dramáticos, literários ou poéticos, ganham dimensão na cena em função da composição entre os elementos visuais, sonoros e táteis. Além disto, registra-se em sua trajetória artística como a encenadora trabalha na fronteira entre diversas técnicas artísticas, criando uma linguagem híbrida que faz uso da performance, do cinema, vídeo e arquitetura.

Como professora de interpretação ${ }^{100}$ da USP, Beth Lopes desenvolve um trabalho que não visa uma linguagem específica, suas proposições parecem se basear na premissa que Pavis elenca como o primeiro aprendizado do ator, isto é, a presença cênica. Para tal, apresenta a seus alunos os meios de estabelecer uma comunicação efetiva com o espectador, de modo que ele tenha conhecimento sobre o que é técnica, o que é espontâneo, como se improvisa, como olhar e se deslocar no espaço.

Ao longo do ano em que os alunos permanecem em sua disciplina, experimentam exercícios de treinamento de energia, segundo os princípios da antropologia teatral, como os exercícios do Verde, do Samurai, da dança dos ventos; mas também exercitam a presença cênica por meio de alguns trabalhos, como círculo neutro, o deslocamento do eixo com a cadeira; desequilíbrios; técnicas de lutas marciais ${ }^{101}$. Desenvolvem, ainda, exercícios com voz em que músicas, sonoridades - aliadas à visualidade e à memória - integram o metier do ator e despertam um espaço de concentração, além de unir os integrantes, criando assim, uma coesão entre o grupo. No entanto, o grande eixo de seu trabalho é fazer com que o aluno tenha consciência do que seria ação física ${ }^{102}$, em suas palavras, "a grande linha que permeia qualquer trabalho de atuação" ${ }^{103}$.

\footnotetext{
100 Destacamos seu trabalho como professora, pois foi nesta ocasião que os atuais integrantes da Cia. se encontraram e decidiram trilhar, juntos, um trabalho de pesquisa continuada que derivou em uma série de produções profissionais. Apresentam-se os procedimentos que a professora utiliza em sala de aula para demonstrar a formação à qual os atores da Cia. foram submetidos. Demonstra-se assim, a base comum de nosso aprendizado.

${ }^{101}$ Tais procedimentos são explicados rigorosamente no livro de Renato Ferracini $A$ arte de não interpretar como poesia corpórea do ator. Campinas: UNICAMP, 2004.

${ }^{102}$ Matteo Bonfitto faz rigorosa análise das ações físicas em seu estudo $O$ ator compositor. Trata inicialmente do conceito em Stanislávski para em seguida examinar o processo de desenvolvimento e alargamento deste, em 
Habitualmente, o primeiro semestre é dedicado a este trabalho que poderíamos classificar como pré-expressivo:

“(...) aquilo que vem antes da expressão, da personagem construída e antes da cena acabada. É o nível onde o ator produz, e principalmente, experimenta todos os elementos técnicos e vitais de suas ações físicas e vocais. É o nível da presença, onde o ator se trabalha, independente de qualquer elemento externo, quer seja o texto, personagem ou cena." ${ }^{104}$

É pertinente denominar pré-expressivo ao trabalho que Beth Lopes desenvolve com seus alunos, pois há nesta definição três princípios que seriam o seu eixo pedagógico. A primeira seria a questão da presença cênica do ator, alcançada por meio do trabalho com elementos técnicos desenvolvidos nos exercícios que visam à consciência do ator em relação à energia produzida por seu corpo; mas também aos recursos corporais que ele deve reconhecer e dominar. Segundo Schechner o treinamento técnico é fundamental, pois é a partir dele que o ator torna-se capaz, em primeiro lugar, de "dominar e dirigir o espírito". Isto parece dizer respeito ao trabalho do ator que, tendo seu corpo como principal instrumento, saiba como apelar a ele e às energias que produz para uma finalidade específica, seja ela determinado tipo de movimento, escolhas das formas, como por exemplo, saber quando e como se sentar, levantar a perna, ou mesmo, um modo de olhar e de sorrir. A segunda razão para o diretor e a mais importante: o fato de que, por meio do treinamento, os atores sejam "capazes de reconhecer certos acontecimentos que ocorrem à sua volta, acontecimentos que são mais fortes do que eles, e de responder a isso." ${ }^{105}$ Essa sugere uma preparação para estar em cena consciente de que durante o espetáculo há diversos fatores externos e internos que podem

outros casos como Meierhold, Grotowski e Barba, passando por Delsarte, Dalcroze e pelo teatro oriental. São Paulo: Perspectiva, 2002. O pesquisador Renato Ferracini, em A arte de interpretar como poesia corpórea do ator, desenvolve uma análise teórica entre interpretação/representação. Para tanto, analisou conceitos importantes como preexpressividade, ação física e vocal e suas subpartes, a emoção, a técnica de ator e seu treinamento cotidiano e sistemático e a codificação de corporeidades como busca de um vocabulário de ações. Passa pelo treinamento energético, técnico e vocal, os trabalhos de ligação entre a pré-expressividade e a expressão e finalmente algumas propostas de utilização das ações físicas e vocais orgânicas e codificadas na montagem de cenas. Apresentam uma proposta estética dos aspectos que constituem a ação física na perspectiva do teatro antropológico.

${ }^{103}$ Entrevista concedida à Lucia Romano, presente em seu livro.

${ }^{104}$ Ferracini, op. cit.

${ }^{105}$ Schechner. In, Féral op. cit. 
gerar interferência. Tal ideia coaduna-se com a noção de espetáculo a qual se refere FischerLichte. Assim, vemos que o treinamento prepara o corpo do ator para o seu desempenho cênico, a fim de que ele saiba recorrer a si mesmo para dominar as forças cotidianas, pois o seu corpo em cena não é somente o da vida comum, mas um conjunto preparado para uma situação específica. Logo, está preparado para gerenciá-las, poderá responder a elas e, até mesmo, incorporá-las. Este seria o segundo princípio que envolve o trabalho da préexpressividade e que parece estar relacionado ao trabalho que Lopes desenvolve com seus alunos. Além disto, como destaca Ferracini, isto que chamamos de pré-expressivo seria uma preparação para o trabalho sobre ação física, o que se harmoniza com a proposta citada por Beth Lopes.

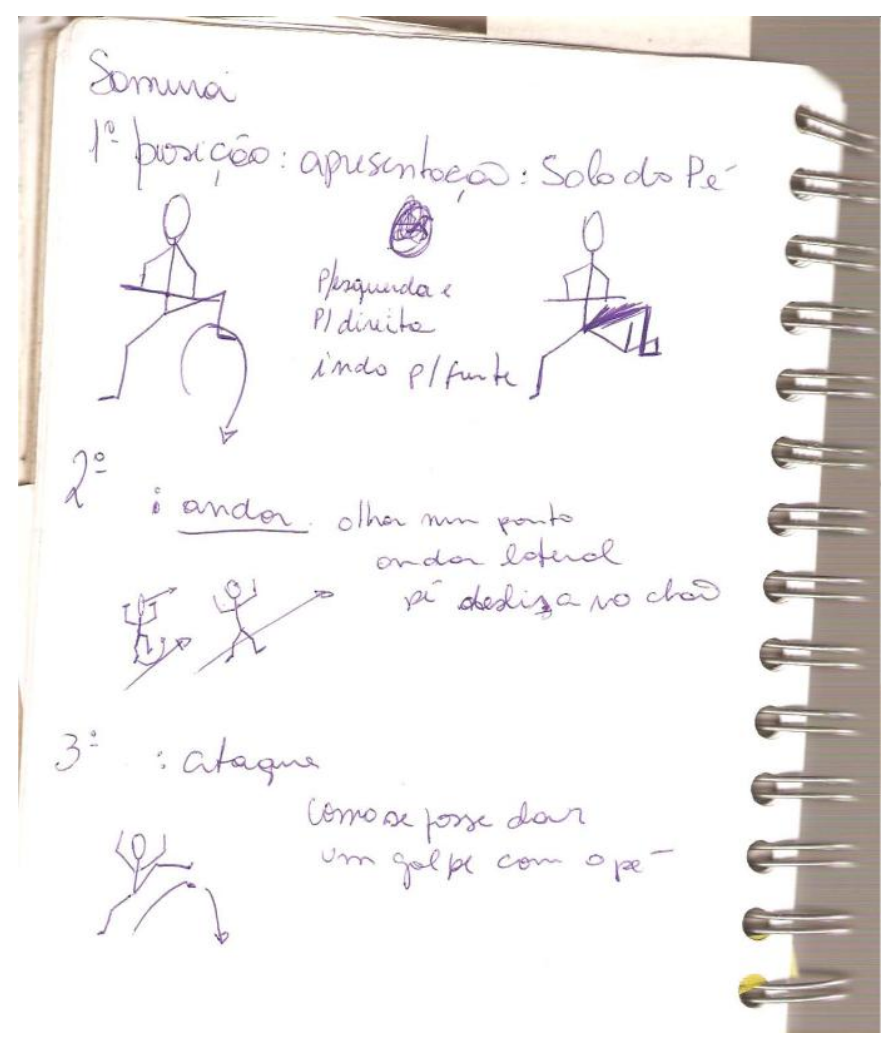

Figura 1 - Nesta imagem podemos observar os movimentos que o corpo desenvolve a partir do trabalho com o Samurai, cuja principal qualidade que este treinamento aciona seria a firmeza. ${ }^{106}$

${ }^{106}$ Anotações no diário de bordo na ocasião em que participei da disciplina oferecida pela professora Beth Lopes. 
Após o primeiro semestre dedicado ao treinamento técnico, a professora passa ao trabalho específico de criação que culmina, ao final da disciplina, na produção de um exercício cênico que se apresenta sobre a forma de espetáculo. Ao longo do trabalho de criação, a professora propõe diversos exercícios para a composição de partituras corporais, derivadas de procedimentos específicos. Neste momento, os alunos experimentam diversos modos de, por exemplo, se levantar, sentar, andar, agachar, associados ao emprego de ritmos diversos, diferentes qualidades de tônus, experimentando fluências, direções, oposições e equilíbrios. Para gerar tais ações, a professora parte de algumas matrizes ${ }^{107}$ utilizadas como material que estimula a criação dos atores, como sonhos, músicas, textos, objetos, paixões. Mas também, orientações diretas, como a exploração de diferentes maneiras de pegar uma flor, de empurrar um fusca, de ser chamado. A seguir, os alunos fazem as próprias escolhas dos movimentos gerados, selecionando segundo o seu critério - normalmente são orientados para escolher aqueles que percebem haver despertado algo em seu corpo.

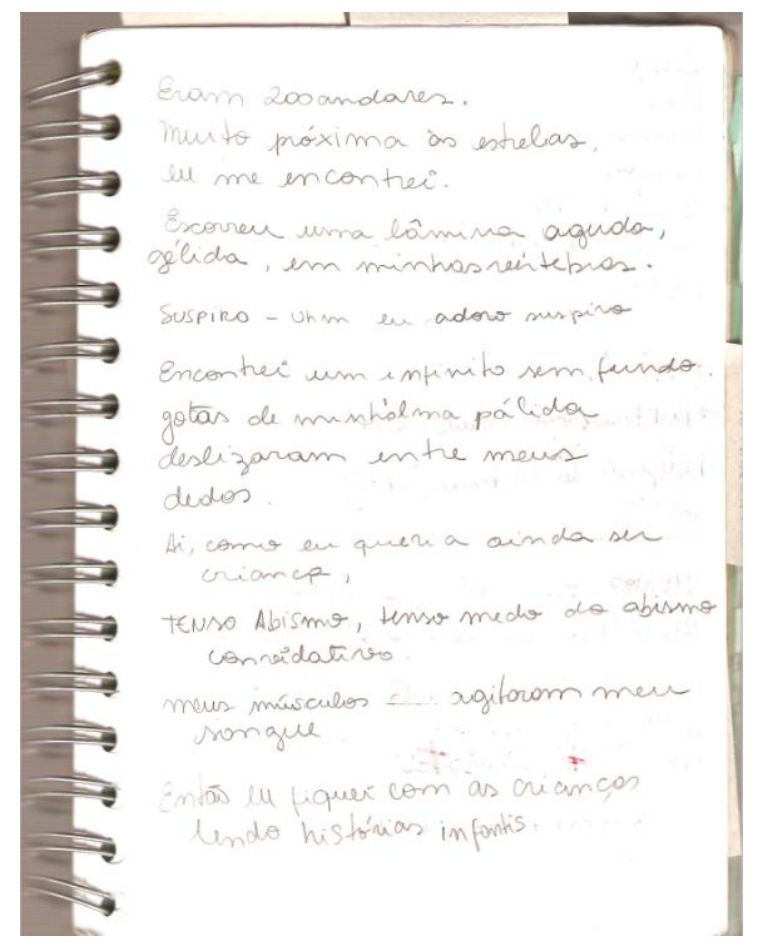

Figura 2 - Descrição de um sonho que tive e que serviu de matriz para geração de movimentos.

107 Matriz, no caso específico de Meierhold, seriam as várias referências artísticas, teatrais e extrateatrais (música, pintura, escultura, dança), utilizadas por ele no processo de construção de sua prática teatral. No mesmo sentido, Matteo Bonfitto define matrizes como sendo qualquer referência utilizada para a confecção de ações físicas (texto dramáticos ou não dramáticos, referências visuais e sonoras, experiências pessoais ou construídas, etc.) Bonfitto, M. op. cit., p.40. 

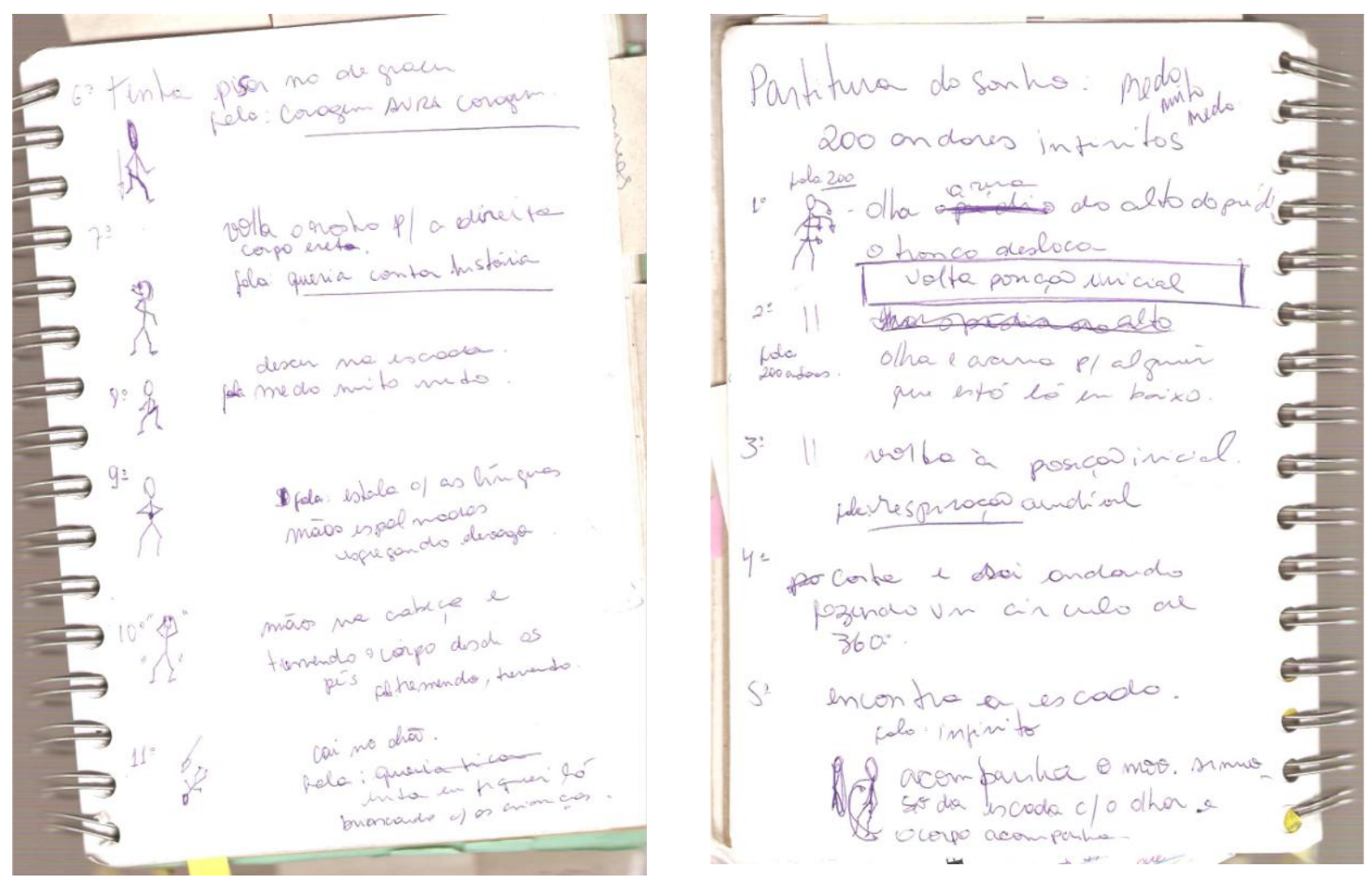

Figura 3 - Descrição e desenhos dos movimentos que foram gerados pelo meu corpo e no meu corpo, a partir do sonho que tive.

Escolhido e definido cada movimento, organizado e trabalhado pelos alunos de modo que cada um seja uma unidade, com início, meio e fim, a professora orienta a turma para a próxima etapa. Significa aquela em que ligamos uma unidade à outra, gerando uma sequência de movimentos, mantendo as qualidades concernentes a cada uma delas, de modo que, ao final, cria-se outra unidade de composição, ou ainda, uma partitura corporal ${ }^{108}$. Após este trabalho, podemos associar textos, músicas, ruídos, objetos, roupas que vão compondo uma situação cênica, ou mesmo, um personagem. Porém, o resultado deste trabalho corporal e expressivo do aluno irá culminar em cena, à medida que a professora vai unindo todas as partituras individuais em uma grande partitura, que seria aquela da representação. Beth Lopes recorta, escolhe, entrecruza, estiliza, justapõe, organizando todos os elementos indicando entradas e saídas, momentos da fala de cada um, etc. Acredita-se que é neste momento que o

\footnotetext{
${ }^{108}$ Consideramos partitura corporal como uma sequência de movimentos executados pelo corpo que tem início, meio e fim.
} 
aluno inicia um trabalho de constituição de ações físicas, se levarmos em conta a noção apresentada por Matteo Bonfitto (2002). Ou seja, o trabalho de justificativa e preenchimento, que segundo o autor, seriam as premissas de uma ação física. Isto porque, é na relação com os outros elementos que constituem a encenação que os alunos passam a criar imagens mentais, objetivos, conexões de modo que vão percebendo como e porque estão naquele universo cênico.

Vale destacar que o trabalho que antecede à composição de ações físicas representa o momento em que o atore/alunos entram em contato e se tornam consciente das energias que produzem, dos impulsos que acionam seus movimentos, da força vibratória de seus corpos. Mas também de seus limites e dificuldades, além de ser o instante que o reconhecem suas habilidades e desenvolvem outras, educam seu corpo e o reconhecem como fenômeno constituído culturalmente. Significa o espaço de aprendizado que envolve técnicas e treinamentos que visam à dilatação do corpo para o contexto teatral, como destacamos anteriormente.

Este é um recorte do trabalho que a professora Beth Lopes desenvolve, no qual ressalta seu empenho em desenvolver habilidades corporais de seus alunos, a tomada de consciência da presença que seu corpo pode ativar uma comunicação com o público, as possibilidades de movimentos criativos que podem ser gerados a partir de diferentes matrizes, e ainda, de como isto pode ser, ao final, um trabalho de composição cênica. Além disto, gostaríamos de enfatizar, que a professora leva em consideração as experiências que cada indivíduo carrega consigo, as qualidades corporais apreendidas anteriormente, e ainda, a autonomia do trabalho do ator em relação à sua criação.

\section{O encontro dos atores com a encenadora}

Desde a fundação da Cia. de Teatro em Quadrinhos, em 1988, muitos artistas e colaboradores passaram pelo grupo, desenvolvendo uma série de trabalhos. Nos últimos cinco anos, o núcleo criativo foi composto por ex-alunos do Dep. de Artes Cênicas da USP. Nosso encontro se deu na ocasião do final do curso de Artes Cênicas no qual convidamos Beth Lopes 
para dirigir nosso trabalho final de interpretação, visto que em função do último exercício cênico desenvolvido em sua disciplina, criamos uma identidade com o trabalho dela.

A partir deste convite ela professora propôs não a montagem de um espetáculo, mas uma série de exercícios nos quais pudéssemos fazer uma pesquisa sobre o trabalho do ator. Em comum acordo, resolvemos que gostaríamos de refletir a respeito do ator e experimentar diferentes níveis de representação. Desenvolvemos, através da experiência criativa, da pesquisa teórica e do trabalho prático, quatro módulos investigativos, com a participação de outros pesquisadores e artistas: a pesquisadora Maria Thaís, com sua experiência na prática de Susuki; a bailarina, diretora e pesquisadora Lícia Moraes, que se empenhou em desenvolver um trabalho sobre a dramaturgia da memória e os procedimentos advindos de sua experiência com a coreógrafa Pina Baush; e ainda Eduardo de Paula que abordou o aspecto prático com enfoque nos procedimentos de composição de ação física.

Eis a pergunta que norteava nossos encontros: Quais os limites entre "representar" e "não-representar"? De fato, não procuramos respostas fixas a cada trabalho, mas a utilizamos como balizadora para nossa pesquisa. O que desejávamos era explorar a tênue linha que separa o certo do errado, a representação da vida, o ator da personagem, o outro de mim. Pois acreditávamos que estes princípios circulavam nos projetos estéticos acerca de um ator que trabalha na contemporaneidade. Destes módulos derivaram três trabalhos práticos: Na caixa com Molly Bloom, no qual utilizamos o último capítulo da obra Ulysses, de Joyce, para um estudo com a palavra. O resultado culminou em uma performance em que os quatro atores permaneceram quatro horas dentro de uma caixa de $4 \mathrm{~m} \times 4 \mathrm{~m}$, com diversas fendas por onde o espectador poderia observar o que se passava lá dentro; Cuidado Frágil! Módulo que contou com a participação de Lícia Moraes que teve como mote crimes contra a humanidade.; e $\mathrm{Na}$

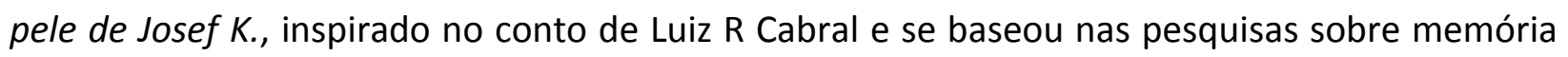
que Beth Lopes desenvolvia em seu pós-doutorado.

O trabalho de Beth Lopes pressupõe que o ator domine o seu material expressivo, desenvolva uma autonomia para a criação, saiba coletar e registrar o material elaborado na pesquisa, além de ter habilidades dramatúrgicas para editar, selecionar, montar, enfim, propor uma organização coerente de seu material. A partir disto, podemos dizer que tais princípios 
educam o olhar do ator tanto para a própria atuação quanto para o trabalho coletivo e da encenação. Ele se integra ao trabalho, aciona e desenvolve seu potencial criativo, além de estabelecer uma ética individual que proporciona a gestão coletiva do trabalho.

Foi no âmbito acadêmico que os atores, junto com a encenadora, encontraram um diálogo comum utilizado em suas produções profissionais que se seguiram, sendo, portanto, a norteadora dos procedimentos criativos. Por havermos nos formado no mesmo curso, desenvolvido uma pesquisa rigorosa com a pesquisadora e professora, em nossas criações profissionais não desenvolvíamos mais um trabalho de pré-expressividade, tampouco um rigoroso trabalho acerca das ações físicas. Já havíamos absorvido tais procedimentos, tanto é que lançávamos mão dele quando necessário. No entanto, desejávamos explorar outros procedimentos de criação conforme a necessidade de cada projeto desenvolvido. À proporção que nos envolvemos de modo seqüencial nas produções, não havia mais necessidade de retomar, a cada novo ciclo de criação, o treinamento comum compartilhado outrora.

\section{A Cia. de Teatro em Quadrinhos (2004-2009)}

A Cia. de Teatro em Quadrinhos traz em seu repertório dos últimos cinco anos a característica de utilizar em suas criações textualidades não dramáticas, por exemplo: contos, romances, textos científicos, poesias, escritos jornalísticos e técnicos e, ainda, textos escritos pelos próprios participantes. Mas, seu repertório conta também com textos dramáticos clássicos como A Tempestade de W. Shakespeare, e autores contemporâneos que não perseguem o modelo dramático ${ }^{109}$, como Atempst on her life, de Martin Crimp - traduzido por (a)tentados pela Cia.

Independentemente do texto utilizado como pretexto para a encenação, este coletivo busca uma teatralidade nas potências visuais e auditivas dos textos, nos quais os integrantes encenadores, atores, iluminadores, enfim criadores/autores da cena - lançam olhares imbuídos de sua subjetividade e encontram ali discursos convergentes ao universo temático que

\footnotetext{
${ }^{109}$ Símbolos de um teatro literário que determinam as formas da cena, definem um universo ficcional, a unidade psicológica e moral do personagem. Tais textos conservam-se na enunciação e na construção de diálogos.
} 
pretendem abordar na obra. O texto se torna, portanto, um trampolim no qual se atiram as reflexões estéticas que orientam a prática do grupo. Na escolha do material textual não pretendemos transladar o texto para a cena, e sim “colocar o texto 'sob tensão' dramática e cênica a fim de experimentar o que é que a enunciação cênica provoca o texto [...] abrindo o texto para muitas interpretações possíveis." 110

Não nos dedicamos à expressão de um sentido previamente existente no texto, expondo seus significados por meio de ações ou gestos. Agimos de modo a constituir uma materialidade da cena a partir de conjeturas externas ao texto, estabelecendo relações com outras artes, lançando mão de materiais que julgamos expandir os sentidos marcados pelo texto, enfatizando o plano espetacular da materialidade da cena. Para tanto, a abordagem do texto se dá por meio do jogo, na cena e com improvisações que se esforçam a extrair dele o material que irá guiar a encenação. Os atores, por meio de seus corpos e expressividades, procuram explorar uma teatralidade espacial e visual projetando uma cena espetacular. Suas criações centram-se mais na imagem e na ação do que no texto, fazendo com que o texto não seja legitimado como centro irradiador da criação, e sim um elemento que compõe o jogo da encenação.

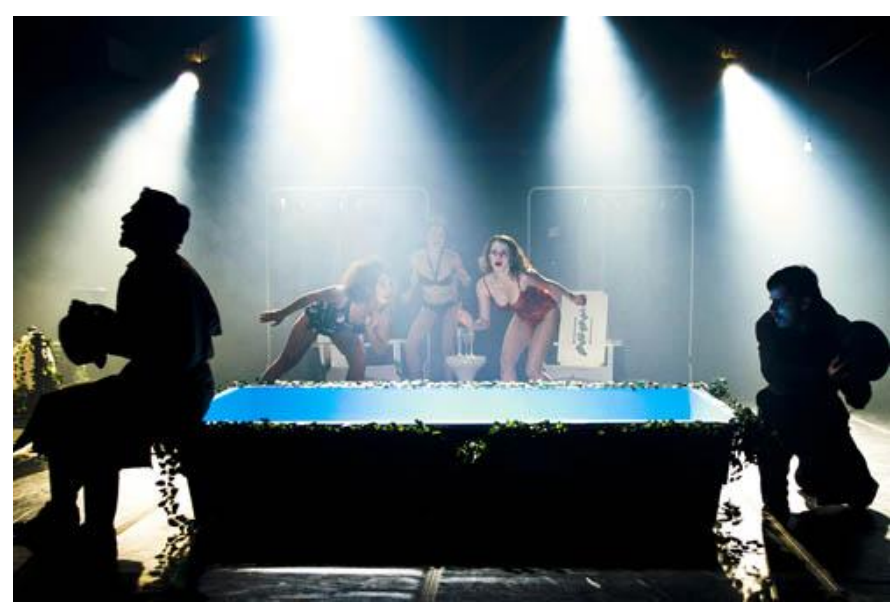

Figura 3 - Foto do espetáculo Anônimos. Onde podemos perceber a composição material da cena como luz, espaço, cenografia, figurino e, ainda, a imagem corporal produzida pelos/nos atores.

Este modo de proceder parece conduzir a Cia. a dialogar com este novo teatro definido por Lehmann como pós-dramático, que “(...) não mais se constrói pelos princípios estruturais do

\footnotetext{
${ }^{110}$ Pavis, P. O Teatro no cruzamento das culturas. São Paulo: Perspectiva, 2008.
} 
drama, ou qualquer narrativa racional. Ele agora se afirma pela presença física e simbólica, impõe-se menos pela fala e mais pelas imagens e sons, menos pela cognição e mais pela sensação. ${ }^{111 "}$

Apesar de todos os esforços para a criação de uma cena espetacular para construir seus projetos artísticos em parâmetros absolutamente cênicos, suas produções por vezes narram histórias $^{112}$ e desenvolvem ação dramática. $\mathrm{O}$ que não invalida a constituição de narrativas sensoriais e a exploração de novas composições de significados.

O fato é que não podemos determinar um modo de proceder da Cia., ou seja, diante de cada projeto, novos procedimentos e consequentemente outras teatralidades surgem. Não há uma coesão que pudesse definir uma linguagem que trabalham. Mas podemos dizer que o circuito permanece na espetacularidade material derivada e composta pelas edificações corporais dos atores.

\section{Atores/encenadores}

O que caracteriza fundamentalmente o trabalho desta companhia é o fato de as cenas serem produzidas na cena, a partir da cena, no jogo dos atores e destes com os outros elementos que constituem o espetáculo. O espaço, a luz, a música, a vestimenta, tudo integra a concepção do espetáculo e é proposto e experimentado na cena. Toda a construção de uma teatralidade não naturalista baseada no ator que é perseguida pela Cia. orienta tanto uma linguagem de interpretação quanto a criação da cena.

Nota-se, ainda, que os atores deste grupo podem ser considerados cocriadores da encenação, pois desenvolvem um trabalho autoral que se manifesta a partir de suas singularidades e expressões, na capacidade de criar cenas a partir de um material oferecido previamente, mas principalmente, criando materiais que advêm de proposições cênicas que eles mesmos sugerem. Isto é, na criação de pequenas cenas onde constroem um discurso material, criando uma tessitura no espaço com seus corpos e com outros elementos que julgam

\footnotetext{
${ }^{111}$ Ramos, L. F. 2006, op. cit.

112 Trata-se da noção de narrativa como meio de organizar e veicular determinada visão de mundo.
} 
necessários para sua composição. O fato de proporem cenas e situações amparadas em elementos cênicos consente aos atores uma exploração abrangente de seu material criativo e expressivo, explorando a gestualidade e a enunciação sem definições prévias. Assim, eles oferecem situações e relações que não visam à configuração de personagens - ainda que sua investida corporal ancorada em determinada situação possa, posteriormente, ser vista como figura dramática, traços de personalidade, máscaras sonoras, posturas corporais.

O modo de criação destes atores é estabelecido em diálogo intenso com a encenadora: o material apresentado por eles são cenas que provêm de indagações, questionamentos, frases, situações, provocações, etc., lançados pela encenadora, mas também, proposto pelos próprios atores. O que parece constituir a base do processo criativo é a proposta de uma organização cênica na qual os atores propõem uma reunião coerente de materiais e têm conhecimento a respeito tanto do objeto que estão edificando quanto das relações que estabelecem entre os materiais cênicos exibidos. Esta produção consciente da obra os legitima enquanto autores/cocriadores da encenação. Vale lembrar que a encenadora, em segunda instância, determina as opções, faz os recortes necessários, mobiliza os deslocamentos, enfim, organiza as partes através de colagens, sobreposições, rupturas e clivagens, mas sempre em debate constante com os atores, que permanecem conscientes das escolhas.

Entende-se que a atitude dos atores que participam do processo de criação da cena, que exploram seus corpos a partir de sua individualidade, motivados por sua subjetividade, revela um olhar dinâmico do ator. Pois em cena eles se mantêm envolvidos no jogo proposto e, ao mesmo tempo, mantêm um olhar para aquilo que estão fazendo, um olhar observador, que projeta uma atuação que oscila entre o jogo e acontecimento. Ou seja, entre as regras e procedimento que determinam o princípio de suas ações e a realidade em que estão inseridos e que contempla a presença do espectador e o espaço no qual ocorre a cena. Assim, eles permanecem entre a atuação e a encenação ${ }^{113}$.

Ao proceder deste jeito, o ator amplia sua participação no processo criativo, envolve-se e opina em sua totalidade, tem atribuições extras e se responsabiliza pelo projeto. Além de

${ }^{113}$ Conforme definido por Fischer-Lichte 
interferir na criação da encenação, ele domina uma prática coletiva e exclui o individualismo. Pode ser, portanto, encenador, pois o pensamento que envolve seu trabalho está diretamente ligado à cena, às articulações dos elementos, à construção dramatúrgica, à escolha dos materiais.

\section{Atores/performers}

Parece-nos que os atores desta Cia. podem ser compreendidos, ainda, como performers, pois eles inscrevem na cena sua subjetividade, fazem uso de seu corpo como matéria e se prestam à criação não de um papel, mas de ações que se integram ao conjunto da encenação $^{114}$. Eles atualizam, não representam, mas agem e deste modo assumem a responsabilidade de suas atitudes e se colocam na intimidade do que estão fazendo, criando ações que derivam do próprio corpo e a partir de suas habilidades. São performers porque são agentes da ação ${ }^{115}$.

O modo de proceder da Cia. vai ao encontro das proposições de Schechner para a elaboração de figuras, situações e ações. Segundo o diretor americano, os atores devem ser capazes de extrair de suas experiências os gestos, deslocamentos, imagens, etc. ${ }^{116}$ No entanto, enfatiza o diretor, estas experiências não seriam somente aquelas da vida comum, mas outras que se experimenta em sala de ensaio, despertadas por estímulos externos que se processam no corpo do ator. Isto leva a pensar que, ainda que todo este material venha a ser recortado, remodelado e organizado segundo a estrutura do espetáculo - a grande partitura, nas palavras de Schechner - os atores relevam na criação as marcas de seus corpos, as expressão de cada indivíduo em particular, o potencial artístico de cada um. Roberto Galizia, em seu estudo a respeito do trabalho de Bob Wilson, parece nos dar a pista deste tipo de criação.

\footnotetext{
"Com efeito, a tendência moderna tem sido a de substituir a palavra 'atuação' por performance (...), pois 'atuação' restringe-se tradicionalmente à prática de interpretar um texto para o público, ao passo que performance é geralmente associada a um certo
}

\footnotetext{
${ }^{114}$ Féral, 2008, op. cit.

${ }^{115}$ Zumthor, P. Performance, recepção e leitura. São Paulo: Cosac Naify, 2007.

${ }^{116}$ Schechner. In, Féral, op. cit.
} 
ecletismo. Contudo a principal razão para a adoção da palavra performance para descrever alguns recentes desenvolvimentos das artes teatrais não é o ecletismo que esta palavra implica, mas o fato de que enfatiza o pessoal, as habilidades individuais do artista, e não a sua capacidade de imitar alguém" ${ }^{117}$

Portanto, designar tal nomenclatura aos integrantes da Cia. significa dizer que enquanto performers estes atores desenvolvem qualidades e habilidades provenientes de seu próprio corpo, reativando seus processos subjetivos. Ou seja, não seria um vocabulário comum corporal ou de pensamento - que a Cia. pretende desenvolver para que todos toquem em uníssono. O que cada um traz para a criação, isto é, suas particularidades comportamentais, suas habilidades corporais e vocais, seu jeito de pensar, suas preferências artísticas, tudo isto não só é absorvido pela criação, como também é vetor para a elaboração de seu material.

\footnotetext{
"Se o termo performer é cada vez mais usado no lugar de ator, é para insistir na ação completada pelo ator, por oposição à representação mimética de um papel. O performer é antes de tudo aquele que está presente de modo físico e psíquico diante do espectador" 118
}

Neste sentido, os atores investem na possibilidade performer, em vez de encontrar uma adequação de seu corpo para um gestual externo a ele. A neutralidade do ator diante desta nova perspectiva, uma neutralidade que pretendia um ator versátil a ponto de se esconder atrás de um papel, que deixava seu corpo transparente para dar vida a outro, não parece ser mais a via que constitui a realidade da cena. Se o personagem não está mais em questão na ordem desta cena contemporânea, foi necessário encontrar outros meios para inscrevê-los nesta cena. Com isso, retirada a máscara mimética, os atores investem seus corpos, seus comportamentos e suas atitudes na cena.

Esta investida, que parece autorizar uma atitude performática por parte dos atores, coaduna-se a alguns dos princípios da performance validados por Paul Zumthor ${ }^{119}$, e que Lúcia Romano, em seu estudo sobre teatro físico, traduz para a realidade teatral de modo claro

\footnotetext{
117 Galizia, L. R. Os Processos criativos de Robert Wilson. São Paulo: Perspectiva, 2004.

${ }^{118}$ Pavis, Análise dos espetáculos, op. cit.

${ }^{119}$ Zumthor emprega o termo para refletir sobre a presença do corpo e suas emanações na poesia oral.
} 
e eminente. Ou seja, os atores nesta conduta são direcionados a um "saber-ser" que trás as seguintes características A) concretizam algo que pode ser reconhecido; B)aparecem num contexto e ali encontram seu lugar; C) implica uma conduta de indivíduos responsáveis por seus atos; D)marcam o conhecimento ao comunicá-lo. ${ }^{120}$ Traduzimos aqui, a partir da realidade da Cia. como a) seus corpos apresentam formas reconhecíveis, são corpos humanos, concretos, realidades irrevogáveis que estão em ação passíveis de criação ${ }^{121}$; b) a cena se caracteriza como lugar de emergência de suas atitudes, de modo que este ambiente legitima a possibilidade da existência de suas situações; c) o comportamento, enquanto conduta moral destes atores, está presente na cena, pois, no ato da criação, eles expressaram seus pensamentos em ações que foram geradas por eles a partir de seus próprios meios; d) eles sabem o que o motivou e porque fazem.

Se o ator cria e instaura uma situação e está consciente do jogo no qual age, isto o capacita a levar para o momento da apresentação uma atitude autônoma, na qual ele pode estabelecer novas realidades, propor mudanças, correndo o risco real de falha ou de sucesso ${ }^{122}$. Neste caso, os atores se colocam em desafios reais, pois agem para modificar o curso daquela realidade inscrita por eles, e na qual eles estão inseridos, promovendo, assim, certa performatividade. Pois, ainda que ele esteja absorto em sua ação, desenvolvendo suas atividades conforme organizadas anteriormente, mantém a consciência do conjunto da encenação e sabe que este espaço pode sofrer modificações: seja em função da reação do público, seja mesmo em função da dinâmica processual que o jogo instaura. Assim, o ator se mantém receptivo e propositivo, porque atua e ao mesmo tempo observa. Esta dinâmica gera um estado criativo destes atores que projetam uma cena tanto quanto uma atuação processual.

\footnotetext{
${ }^{120}$ Romano, L. O Teatro do Corpo Manifesto: Teatro Físico. São Paulo: Perspectiva/FAPESP, 2005.

${ }^{121}$ Criação como aquela aferida à teatralidade, em que o espectador projeta sobre os corpos uma projeção ficcional.

${ }^{122}$ Féral apresenta as reflexões de Derrida para tratar do teatro performativo. Segundo a autora, o filósofo determina estes dois termos como sendo constitutivos da performatividade, uma vez que uma obra pode ou não alcançar seu objetivo final. "A ação contida no enunciado performativo pode ou não ser efetiva". Assim, o risco de jogar com a realidade da cena e propor mudanças nas situações estabelecidas traz consigo o fator da falha ou do sucesso.
} 
Neste sentido, pode-se traçar um paralelo deste modo de proceder da Cia. às ideias de Renato Cohen e suas reflexões a respeito do work In Progress ${ }^{123}$ cujas características se definem por: não partir de condições estabelecidas a priori (texto, autoria, personagem); organizar-se por meio de ações que os performers experimentam em sala de ensaio e que interferem no roteiro; implicar sucessivas mutações, evitando fixar-se como produto final; substituir a narrativa clássica pela organização espacial em que vários elementos aparecem simultaneamente, o que desmancha o paralelo entre sentido e representação ${ }^{124}$. Isto porque nos parece que o fato de a cena se organizar a partir das ações dos atores faz com que eles proponham, no momento da realização do espetáculo, mudanças que interferem em seu desenrolar. Mas este não seria um movimento involuntário, tal proposta está na base do jogo sugerido pela Cia. Ou seja, os atores estão autorizados, dispostos e disponíveis para instaurar modificações, precipitando assim, certo aspecto lúdico no jogo, além de deixar a cena viva e propositiva: o espetáculo não se fixa em um produto final e acabado, mas se mantém sempre aberto a novas proposições.

A proposta desta companhia não fixa o ator na função de exercer um papel que visa ao bem desenrolar da engrenagem teatral, mas pretende sinalizá-lo como presença viva, como ser que age. Pois ele não é obrigado a chegar a algo externo a ele, é o próprio ator que dinamiza suas forças criativas para atualizar um comportamento e se colocar em situação. Ele cria suas situações e com isso se detém como executor que aciona a própria realidade que cria.

\section{Procedimento performático}

Pode-se considerar certa ausência de treinamento específico que garanta uma sintonia no desempenho destes atores, porque a teatralidade explorada por eles está mais calcada nas idiossincrasias de cada artista, no potencial gestual de cada corpo, na qualidade expressiva de cada participante do que na expressão de uma linguagem interpretativa comum. No entanto, a

\footnotetext{
${ }^{123}$ Características baseadas nas leituras de Geraldi, Silvia, M. O estado de ser e não ser das artes performativas contemporâneas. Revista digital: http://www.fap.pr.gov.br/arquivos/File/RevistaCientifica3/18_Silvia_Geraldi.pdf.

124 Tais características podem ser observadas tanto no chamado teatro pós-dramático, quanto no teatro performativo, como apresentamos anteriormente.
} 
cada novo projeto em que se engajm, em cada novo material escolhido para uma produção, pode-se considerar que há um denominador comum em seus procedimentos: os atores trazem propostas de ações/cenas/quadros que são integradas ao espetáculo. Arriscamos chamar a tais ações de atos performativos presenciados no âmbito da criação, em um primeiro momento e inseridos no contexto do espetáculo em um segundo momento.

Explica-se: Estimulados pelo material em questão, os atores procedem de modo a desenvolver pequenos quadros/encenações em que expõem imagens, sonoridades, elementos cenográficos e de vestimenta, onde criam um universo imagético em que se situa suas ações. Em diversos casos, os movimentos, gestos e deslocamentos propostos tona-se um roteiro de ações que irá compor a cena posteriormente. Porém, quando derivadas deste modo de proceder, suas ações não têm como elementos constitutivos o preenchimento e as justificativas das quais prescindem as ações físicas. Logo, não se pode falar que os atores segundo este procedimento desenvolvem ações físicas porque seus movimentos não são preenchidos de um como e um porquê, não se trata de ação objetivada.

Arrisca-se dizer que estes atores "presentavam" pequenos atos performáticos, pois escolhiam os materiais, organizavam os elementos, expunham suas ideias a respeito do tema em questão e com isto realizavam atividades, gestos, movimentos e deslocamentos em cada situação. Trata-se de um pequeno evento apresentado aos olhos dos outros criadores da cena. Nada era ensaiado, tudo se desenvolvia naquele momento e naquela situação: significava um pensamento que os atores materializavam naquele instante. Deduz-se que as ações que desenvolviam ali se aproximam da ação como práxis $^{125}$, pois não tinham outra finalidade,

\footnotetext{
${ }^{125}$ Achamos conveniente apresentar o conceito, pois nos parece que ele dimensiona tal atividade que resvala no princípio do real, visto que o acontecimento o que nos remetemos ao longo do trabalho parece tocar em tal conceito. A tentativa foi a de aproximar a noção de to performer, que pressupõe a execução de ações, segundo Féral, e a definição de ação apresentada aqui por Marilena Chauí. Encontramos tal definição em seu livro Introdução à história da filosofia. São Paulo: Companhia da Letras, 2002. Práxis: ação, ato (por oposição a fabricação, poiésis); atividade (por oposição a paixão, passividade, pathós); realização, maneira de agir, maneira de ser. O verbo pratto significa (...) executar, agir, cumprir, realizar, conseguir, fazer acontecer alguma coisa, fazer por si mesmo. Uma prática na qual o agente, o ato ou ação são inseparáveis. Uma atividade ética e política inerente aos homens livres, racionalistas e reflexivos de suas ações. Por oposição a poiésis, significa dizer que esta seria uma atividade mecânica caracterizada por uma rotina mecânica em que o agente, a finalidade e a ação são diferentes e independentes. Vale acrescentar, para demonstrar nosso raciocínio, o fato de o verbo inglês to perform trazer
} 
naquele contexto, senão a de expor uma situação, realizar uma atividade, porque faziam acontecer alguma coisa, ou mesmo, agiam para que alguma coisa acontecesse, característica que nos remete novamente ao princípio do performativo que Féral defende.

Obviamente, havia uma finalidade artística, ou seja, estávamos ali para a criação de uma poiésis, de uma obra artística. Aquele momento não era uma prática da vida, era uma prática que se destinava a uma composição. Acreditamos que as ações não tinham como finalidade a construção da máscara de um personagem, mas a elaboração de uma situação, de uma visualidade que deveria ser percebida e sentida naquele momento. E quando suas ações eram inseridas no contexto do espetáculo, os atores se dispunham a manter a mesma postura tomada no momento em que as realizou pela primeira vez, na ocasião do ensaio. Assim é que muitas vezes os atores não ensaiavam meticulosamente suas cenas, isto significa dizer que os atores sabiam o que deveriam fazer naquela situação, sabiam das atitudes e dos comportamentos que deveriam tomar diante do fato, mas não tinham repetido a situação de modo a fixar uma atitude em cena. Podemos dizer que suas ações eram com roteiros, ou seja, eles deveriam andar até uma mesa, subir nela, sentar-se em uma cadeira e responder algumas perguntas; a situação instaurada era tensa e havia luzes vermelhas tingindo o ambiente - a exemplo da cena que compõe o espetáculo (a)tentados ilustrada abaixo, na figura 4 . Isto é, havia uma situação em um contexto de representação na qual os atores estariam agindo e que estava ambientalizada para evocar certa tensão. Mas, nos parece que o que determinava certa intensidade à cena e acionava os recursos expressivos dos atores, como a tensão de seus músculos, a dinâmica da sua respiração, a direção e força de seus olhares, adivinham do risco real a que estavam expostos: o perigo de cair da mesa, de ser atacados pelo cacete, de ser atropelados pela mesa enquanto esta desliza pelo palco. E menos pela consciência das forças produzidas no momento do pequeno evento performático presentado aos seus pares, ou mesmo pela constituição das ações físicas, experimentadas, detectadas e memorizadas, no momento da criação e acionadas no momento da representação. Dito de outro modo, não são ações justificadas e preenchidas, mas forças que são acionadas pela situação em que o ator

consigo definições que poderiam se aproximar do verbo grego pratto. To Perform seria então traduzido como: realizar, fazer, cumprir, efetuar, representar, levar a cabo. 
experimenta no momento mesmo da representação. Assim, aquilo que acionava a expressividade dos atores, a situação imaginária a qual eles poderiam projetar, enfim, a potência geradora de teatralidade adivinha mais do jogo entre os atores, dos elementos da cena e das atividades que realizavam, do que vinculada a um objetivo dentro do contexto do espetáculo que pudesse conferir sentido às suas ações. Podemos falar que estamos mais próximo de certa performatividade vinculada à ordem do real, do que de fato, a uma organização formal da construção de uma partitura. O que aquela figura fazia, porque estava ali e o que queria dizer com a sua presença ali não era o que determinava sua ação.
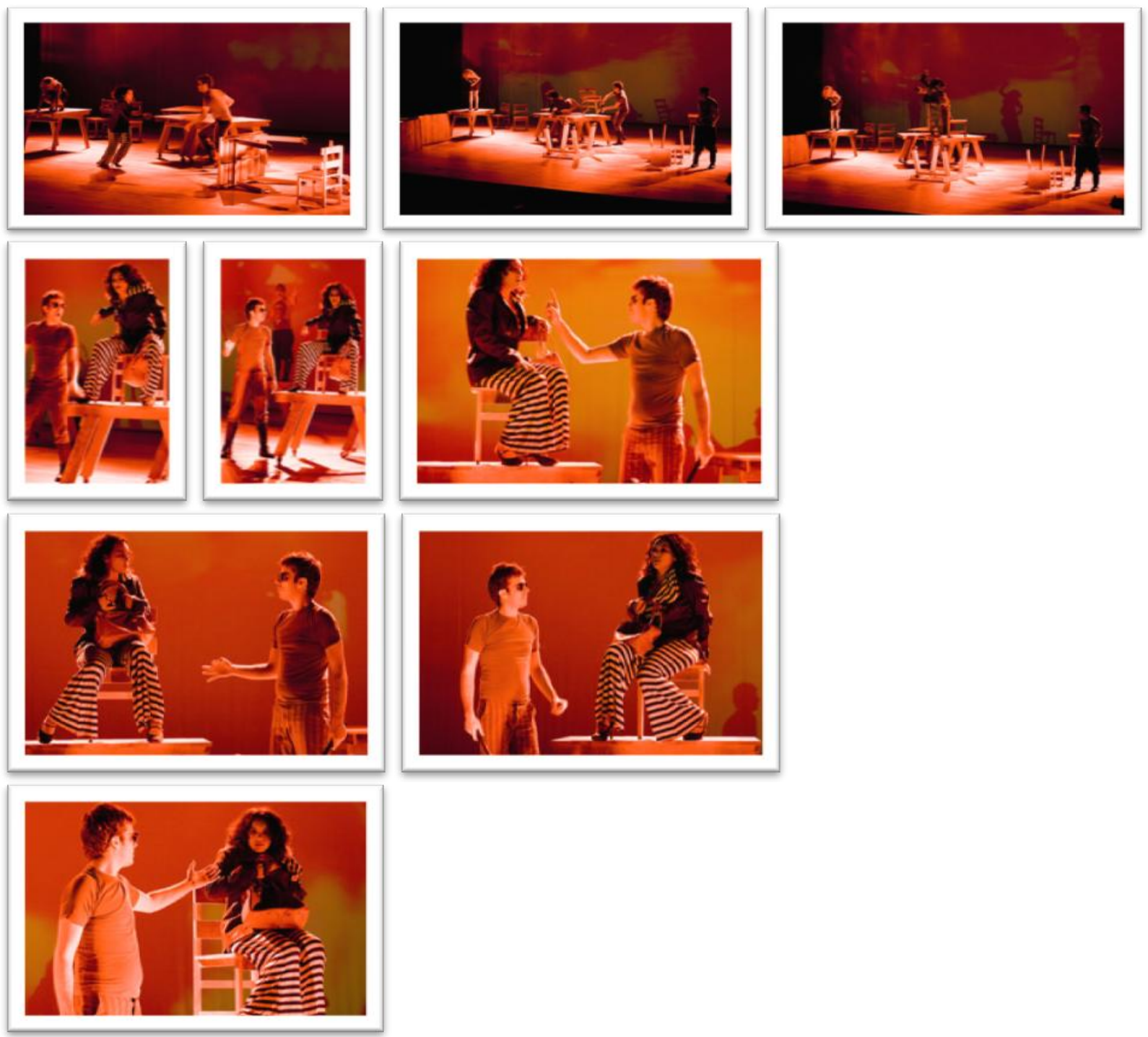

Figura 4 - Fostos do espetáculo (a)tentados. Sequencia a qual podemos observar a movimentação roteirizda dos atores. 
Assim, pode-se afirmar que suas ações em cena não visavam a constituição de um personagem, o foco em questão era a sua atividade que, inserida e recontextualizada em um campo de produção simbólica (teatralidade), poderia ganhar dimensões ficcionais aos olhos do espectador tanto quanto na intenção do ator, de maneira que poderiam ser reconhecidas e identificadas dentro de um contexto fictício. No entanto, os atores permaneciam fazendo o que deveriam fazer sem a intenção de procurar uma justificativa para sua ação. Quando estas cenas/quadros eram deslocadas para outro "cenário" - o espaço do espetáculo, com a presença do público, isto poderia potencializar e disseminar novas relações entre os participantes, mas estas relações poderiam não ser definidas a priori. Tal forma de proceder para a criação da cena parece procurar gestos, movimentos, particularidades, sonoridades, antes de qualquer ação física. Insistimos mais numa vez no aspecto gestual porque o consideramos fundamental para pensarmos o ator em cena como imagem potencial. É possível, assim, agrupar neste procedimento algumas características que parecem ir de encontro com uma cena performativa:

a) o princípio da ação enquanto fazer e agir, de modo que não prescinde de personagem, tampouco se realiza enquanto ação física; b) os atores que manipulam os espaços, seus corpos e outros elementos da cena; c) o que apresentam se realiza naquele momento, seja em sala de ensaio, seja mesmo no espetáculo, d) leva em consideração o risco real da cena; e) instaura um caráter lúdico na cena.

Este seria o ponto de vista, portanto, de uma criação que surge de pequenos atos performativos que constituem os procedimentos que irão desembocar em uma cena que leva em consideração o princípio do evento: eles agirão novamente, mas, levam consigo a consciência de que o farão em outro lugar, envoltos de outros elementos, com pessoas (público) diferentes e que devem considerar, antes de tudo, a situação presente em que estão inseridos. Além disto, não figuram personagem, mas antes, podem ser vistos como uma imagem que está em condição gestual, corporal e material. Seria, enfim, uma cena que nasce da cena, que se presta enquanto evento e que se pauta na materialidade dos elementos que a constituem. 


\section{A composição de movimentos}

Outro procedimento utilizado pelos atores desta companhia diz respeito à criação de partitura, ou seja, a criação de uma sequência de movimentos dinamizados por várias matrizes geradoras. Evita-se falar na composição de ação física, pois acreditamos que falar de movimentos gerados pelo corpo no espaço parece caracterizar uma gestualidade e uma corporeidade que se pode perceber em cena, sem que em princípio façamos qualquer distinção sobre quem ou o que poderia ser aquele ser que se movimenta diante de nós. Consideramos, entretanto, que uma ação física para o pesquisador, professor e ator Renato Ferracini pode apontar para uma figura cênica e trazer índices de leitura em seu comportamento, ou seja, a ação física não seria definidora de um personagem fictício, mas poderia indicar as possibilidades de que aquela composição corporal pudesse ser alguém ou alguma coisa em função dos elementos que a compõem, além de serem dinamizadoras das potências expressivas do corpo ${ }^{126}$. Mesmo assim, pode-se perceber, em alguns casos, que a gestualidade organizada a partir de matrizes geradoras podem ser apenas deslocamentos de diferentes dinâmicas que surgem na paisagem da cena. Apresentamos o seguinte exemplo para melhor ilustrar tal consideração.

Uma atriz desenvolveu uma sequência de movimentos que foram gerados a partir da lembrança de um encontro feliz e prazeroso que marcou sua vida. Primeiramente, ela ilustrou de modo sintético as passagens desta pequena narrativa: passou por diferentes estados emocionais, imprimiu diferentes ritmos conforme a situação que surgia, deslocou-se de um lugar a outro, sentou-se, olhou para frente, virou a cabeça para o lado e sorriu, deixou o vento soprar o seu rosto e demonstrou prazer nisto. Esta foi a primeira experiência. Em seguida ela trabalhou cada etapa de sua curta narrativa, de modo distanciado, cortando, reorganizando, introduzindo novos elementos rítmicos, novas respirações, pausas, enfim reconheceu cada gesto, ritmo e olhar. Pode-se dizer que ela codificou seus movimentos e, neste momento, ela não trabalha mais no nível da emoção que parece haver sentido na primeira vez. Parece-nos, assim, que o primeiro momento povoado de emoções fortes advindas de suas lembranças foi

\footnotetext{
${ }^{126}$ Ferracini, op. cit.
} 
somente um pretexto para a geração e criações de movimentos e tensões. No segundo momento, suas atitudes gestuais viraram experiências corporais que a atriz foi, pouco a pouco, afinando, de modo que ela vai descobrindo as possibilidades do seu corpo diante de determinada situação. Deste fato, pode-se dizer que ela chega a uma estrutura não como algo fixo e reproduzível, mas como define Tatiana Motta em seu rigoroso estudo “'Estrutura' e 'espontaneidade' em Grotowski":

"Construir uma estrutura não é um processo de trazer
à consciência a totalidade do comportamento cênico, e
sim um processo de construção de âncoras, de pontos
de referência que evitam a dispersão, impõe uma
direção e, assim, permitem e exigem sempre novas
descobertas, desenvolvimento e ajustes." 127

Logo, deduz-se que a atriz, a partir desta estrutura, não determinou um comportamento que seria reproduzido na realização da cena. E mesmo que tenha codificado seus movimentos e impulsos, isto é, ainda que tenha consciência da força que imprimiu neste ou naquele movimento, aquilo que realizou e como realizou, serviu apenas de um roteiro para possíveis ações, do que de fato em uma organização fixa que ela deveria reproduzir no palco. As ações que gerou serviram mais como referências para aquilo que poderia realizar em cena em determinada situação. Ou seja, ela vai correr, vai pular na mesa, saltar e bater em seu rosto. Ainda que vá desempenhar tais ações, a ordem, o momento, o lugar que realizará tal gesto não está definido por uma estrutura fixa. Isto porque, na construção dramatúrgica da cena, a criação da sequência de movimentos produzida pela atriz torna-se mais um elemento que irá ser integrada à partitura da representação. Os movimentos gerados tornam-se material que será levado para cena e disposto em relação a outros elementos. Esta sequência de movimentos, ao entrar em contato com os outros elementos da cena, transforma-se, aderindo àquela realidade, de modo que se desmembra da matriz que a gerou, que estaria ligada à situação que imaginou e, consequentemente, à emoção que sentiu. Portanto, pode-se dizer que o que potencializa suas ações quando em cena é o ambiente, o espaço, a luz, a relação com a ação do outro e não as forças que foram produzidas no momento da criação.

${ }^{127}$ Motta, Sala Preta, Revista de Artes Cênicas/USP, n 5, 2005. 
Em outras palavras, a estrutura que a atriz codificou, quando colocada em relação aos outros elementos da cena, se transformou, se desenvolveu e se "ajustou". Isto é, novas descobertas foram feitas e novas realidades foram construídas. Se o ator e pesquisador Matteo Bonfitto chama atenção para a ressignificação das ações físicas quando dimensionadas no espaço e colocadas em relação a outros elementos da cena, ele continua insistindo que as "ações físicas estão conectadas com desejos e vontade" ${ }^{128}$. Assim, no trabalho descrito acima, parece não haver desejo nem vontade operando, no sentido de um objetivo expresso pela ordem narrativa, ou pela ressonância dos aspectos sensíveis que a atriz experimentou e que poderiam compor a vida de um personagem. Mas sim, a articulação e dinamização de suas ações tratadas como elementos materiais para a composição de uma paisagem. Ou seja, o que a atriz fazia era apenas subir na mesa de modo arriscado, correr, jogar as pernas para o alto, parar diante da plateia, fazer um sinal de tchau. No entanto, nada disso era justificado nem pretendia ser, por parte da atriz, um personagem específico, não havia uma imagem interna que preenchia sua ação.

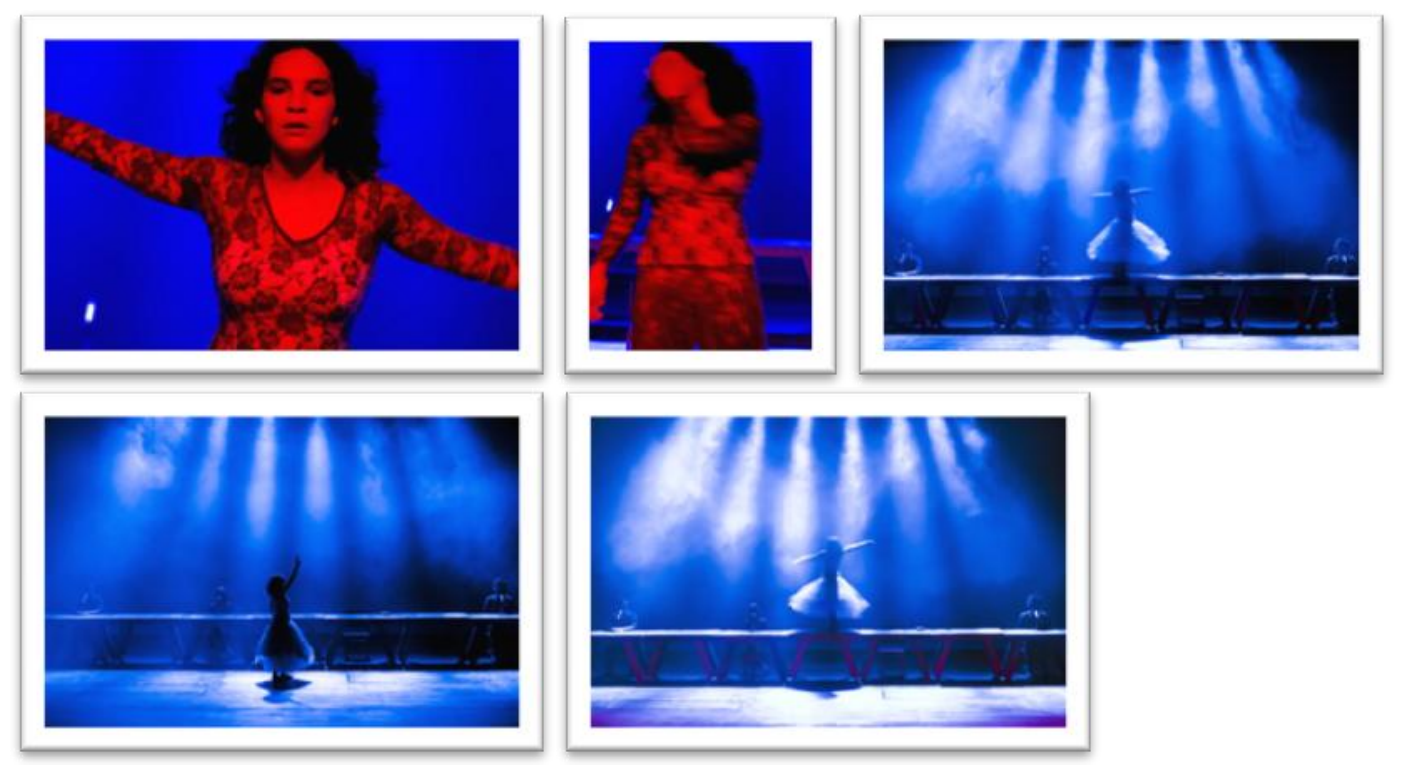

Figura 5 - Cena do espetáculo (a)tentado.

Pode-se perceber, nestas imagens, a materialidade do espetáculo, a construção plástica, de modo que o corpo da atriz é somente mais uma imagem que se movimenta no espaço.

${ }^{128}$ Bonfitto, op. cit. 
Apesar de ter constituído toda uma sequência de ação, ela não está ali para definir uma situação específica. É o vestido da atriz somado à luz que incide sobre ela, a fumaça que a envolve, o vídeo de uma tela de TV sem sintonia ao fundo que ganham gravidade em cena. A atriz ali não pretendia criar um signo autônomo e propor uma forma legível, tampouco ações que poderiam ser reconhecidas. O que está em questão é a imagem produzida pelo conjunto e por sua expressividade corporal. Assim, ela se coloca como mais um dos elementos que se conjugam na encenação. Seu corpo e seu gesto não pretendem dizer nada, não estão dispostos para uma leitura coerente. Seu corpo é matéria desenhada e tingida que parece, em meio à plasticidade da cena, prescindir dos componentes da ação física.

Em outra situação, a mesma atriz apresenta o modo com que lida com as ações que desempenha em cena. Em diálogo com sua diretora, a atriz comenta:

A (atriz) - Mas eu só estou rodando e segurando uma bolsa!

B (diretora) - Não há nenhuma construção mental que justifique esta sua ação?

A - Não, eu apenas estou girando e segurando uma bolsa. Claro que eu sei que tem outro ator olhando a minha atitude, outra que borrifa água em cima de mim, que há um texto sendo proferido e que está sobreposto à minha ação. Mas, de fato, eu não estou imprimindo nenhuma intenção na minha ação!

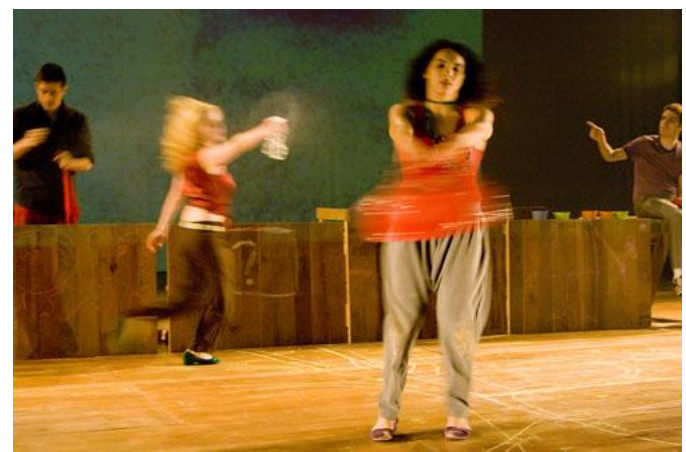

Figura 6 - Cena do espetáculo (a)tentados a qual a atriz menciona em seu diálogo.

Percebe-se neste diálogo que a diretora chama a atenção da atriz para uma construção mental que possa justificar sua atitude em cena. No entanto, ela não havia elaborado mentalmente nenhuma imagem que pudesse dar intenção à sua ação. Talvez isto faça que sua atividade esteja mais próxima do gesto, do movimento, do que de fato de uma ação física. 
Acredita-se que seria possível estar em cena apenas como imagem expressa por uma corporeidade. Não porque julgamos que uma ação física esteja sujeita a um personagem, mas porque uma ação pode apenas ser um deslocamento, uma atividade de forma que o corpo possa ser percebido como mais uma imagem em movimento sem que a intenção do ator sugira um comportamento a priori. Ainda que uma ação física seja um balizador para a condução do ator em cena, um catalisador de suas energias, um modo de fazer com que o ator "domine as forças que o dominam" ${ }^{129}$; ainda que a ação física "visa essencialmente permitir ao ator construir uma partitura física precisa que possa ser reproduzida" ${ }^{130}$, falar em ação física em termos de partitura parece determinar certa organização de signos, ao passo que as ações da atriz descritas acima estão mais próximas de uma atividade cotidiana, ou seja, sentar, pular, correr, rodar. Assim, nos parece que ela ganha dimensão mais pela dispensa energética e física que o corpo disponibiliza para efetuar tais movimentos, pela presença dos outros elementos da cena, e ainda pela sua atitude de querer estar naquele momento presente, do que por uma organização codificada.

\section{Presença e evento}

Segundo Lehmann, quando se retirou o personagem da cena, quando se aboliu o cosmo fictício, o teatro enfatizou, por um ângulo, os corpos dos atores para que tenhamos consciência de que aquilo que se apresenta em cena são corpos reais de pessoas reais. Em contrapartida, a cena se tornou um evento, ou seja, uma realidade que ocorre naquele espaço e tempo, mobilizados por determinados corpos e elementos que mobilizam uma comunicação ${ }^{131}$.

Seguindo o mesmo pensamento, Schechner relaciona a presença do ator vivo ao princípio da eventualidade:

\footnotetext{
${ }^{129}$ Schechner. op. cit.

${ }^{130}$ Motta, op. cit.

${ }^{131}$ Lehmann, op. cit.
} 


\begin{abstract}
"Penso que essa presença tem a ver com a noção de eventualidade. Em outras palavras, quando o espectador percebe que o ator não pode só mudar o que está fazendo, mas que pode também ser dono dessa mudança, que não tem que mudar, mas pode eventualmente fazê-lo, nesse momento, o ator tem presença." 132
\end{abstract}

No caso dos atores da Cia. e mais precisamente no caso do espetáculo (a)tentados, esta noção de presença e de evento são fatores intimamente ligados. Pois, ainda que os atores tenham consciência do que devem fazer na cena, a estrutura do espetáculo permite-lhes promover certas mudanças no decorrer da situação, mas, tais modificações não são feitas de modo que a cena perca completamente sua estrutura. Isto se dá em decorrência do uso que fazem de alguns princípios que acompanham a noção de jogo. Ou seja, há regras preestabelecidas, espaço e tempo definidos; há solicitação de uma ação pessoal e uma dinâmica que depende da predisposição do indivíduo e de suas características. Quer dizer, as respostas lançadas diante das circunstâncias apresentadas estariam restritas aos recursos e competências de cada jogador.

Pode-se dizer que a estruturada utilizada no espetáculo motiva ações possíveis decorrentes de uma ação pessoal. Porém, acreditamos que tais ações estão em convergência às regras estabelecidas em função da linguagem que se pretende, e ainda, dizem respeito à acumulação memorial do universo referencial levantado no processo de criação da cena. Percebe-se então que elas se mantêm em espaço virtual ${ }^{133}$, de modo que o acúmulo dos materiais, isto é, temas, imagens, músicas, filmes e sonhos permaneçam em nosso imaginário e podem ser presentificadas no ato cênico, a partir das possibilidades que vão se configurando em cena. O acúmulo permanece em estado virtual, pois diante de circunstâncias inesperadas pode-se lançar mão de ações que podem estar em convergência com as novas configurações propostas no momento do espetáculo. Trata-se, pois, da noção de jogo em relação à presença e o evento, pois, da mesma maneira que "o jogo cria uma dinâmica processual, pois não prevê

\footnotetext{
${ }^{132}$ Schechner, op. cit.

${ }^{133}$ Neste caso, o virtual deve ser considerado na ordem do pressentir que se associa ao sentido e por vezes se identifica com ele. Diz respeito àquela estranha sensação que temos diante de um objeto que percebemos e, no entanto, algo lateja em sentido que ainda não conseguimos conceber. Algo que ainda não é imagem (mental) constituída, mas é imaginável e tem a possibilidade de produzir uma imagem.
} 
um resultado objetivo, e sim a produção do sujeito em ação" ${ }^{134}$ a proposta do espetáculo é deixar que o ator perceba as relações que decorrem de suas proposições e que possa completar sua ação a partir do imaginário que provém de suas memórias e lembrança acumuladas. Assim, o jogo parece solicitar a atenção do ator às propostas que o outro pode estabelecer em cena e saber responder a isto, mas também, propor novas configurações na cena. Esta conjuntura parece exigir um estado de presença e projetar a noção de evento.

Somado a este princípio que acompanha a noção de jogo, o plano de eventualidade e da presença leva-nos a outro fator que se opera no teatro performativo sugerido por Féral, o risco. Existe o risco real do jogo, pois o ator, em sua proposta, pode não atingir um resultado, no sentido de que a sua proposta possa não estar em coerência com a estrutura do espetáculo, criando fugas que desestabilizam a proposta da encenação. Mas, em contrapartida, há o risco real dos corpos em cena. Pode-se perceber tanto um quanto outro, na penúltima cena do espetáculo (a)tentados (Figura 7), quando os atores retomam de modo frenético e caótico todas as ações desempenhadas por eles ao longo do espetáculo, que foram acumuladas ao longo do jogo cênico e permanecem como possíveis ações a ser retomadas.

Neste caso, a opção da encenação foi trazer o caráter de síntese das diversas ações que os atores realizaram ao longo do espetáculo, do mesmo jeito que o texto de Crimp apresenta em seu início diversos recados na secretária eletrônica, que indicam as situações, ou mesmo, as identidades que a personagem Anne poderia ter ao longo do espetáculo. No entanto, na retomada das ações, a proposta era realizá-las com as mesas que compunham o cenário, isto é, os atores deveriam projetar suas ações de forma que pudessem se relacionar com esses objetos. Em ritmo acelerado e em movimentação desordenada, os atores pulavam, corriam, giravam a mesa, passavam por baixo dela, etc. Era possível perceber nesta movimentação o perigo a que os corpos estavam expostos, mas também um estado de possíveis acontecimentos que derivariam deste jogo.

Isto trouxe para a cena o caráter de eventualidade que envolve a presença, pois o espectador percebe que os atores são atores - corpos reais - e que se encontram em situação

\footnotetext{
${ }^{134}$ FÉRAL, 1985, op. cit.
} 
de perigo real: risco de se machucar, de se ferir, de cair, de bater com a cabeça na mesa. Mas também em possibilidade de fazer uma ou outra coisa, pois suas ações, e isto era visível, não estavam completamente determinadas. A presença não seria algo percebido somente pelo espectador, mas era consciente e necessária por parte do artista, que deveria saber manipular o objeto e desenvolver suas ações, estando ao mesmo tempo ciente e atento ao movimento do outro e o que poderia propor diante dele. Isto porque não havia uma organização estrutural de quem fazia o que e quando. Tal premissa exigia do ator a presença necessária para observar o outro e ao mesmo tempo manter-se concentrado às suas ações. Pois, ainda que soubessem quais movimentos deveriam executar, não fixaram um início, um meio e um fim, de modo que todos deveriam estar atentos e presentes.

O caráter de evento provém, acredita-se, do estado a que se refere Schechner, isto é, o ator pode mudar seu deslocamento, pode ir para a direita ou para a esquerda, o público, por sua vez percebe seu movimento. Da condição de risco que envolve a percepção da presença do ator parece emergir um estado de suspensão e de vigilância que mantém ator e público atados. Mas também imprime um contato e uma cumplicidade entre eles, promovidos pela percepção real de seus corpos em perigo, desencadeados pelo princípio do evento e pela proposição do estado de jogo.

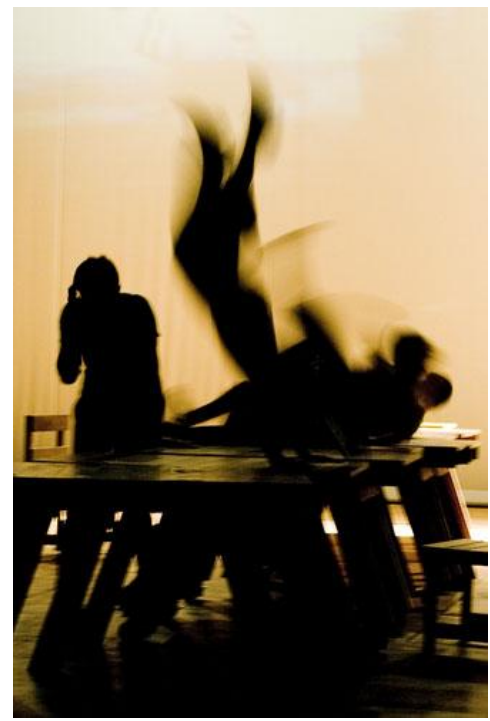

Figura 7 - Cena final do espetáculo (a)tentados: corpo e risco real. 
Assim é que acreditamos que este jeito de proceder, que pressupõe o jogo e o risco que dele advêm, parece propor uma marca de atuar que leva em consideração a noção de presença: os atores manipulam o espaço e os objetos conforme o próprio repertório, mas o modificam em função do agir do outro; eles se colocam em situações de risco, pois não pretendem fixar suas ações para que possam desenvolvê-las de modo confortável, sem a possibilidade real de se machucar. Ainda que todos os participantes compactuem com as regras estabelecidas, estar-se em jogo seria comportar-se como um receptáculo ativo e em constante processo de criação de imagens e de realização de ações, levando em conta as ameaças reais que derivam desta proposta.

\section{Texto e Cia.}

Ao explanar a respeito de dramaturgias contemporâneas e, mais precisamente, sobre a condição dos diferentes usos de elementos textuais em um espetáculo, Josette Féral explora a noção de texto espetacular, definindo-o como todo e qualquer texto que é levado para a cena e que é o resultado de uma tessitura entre o texto e todos os elementos da cena. Desdobrando esta noção, a autora traz à luz a ideia de texto performativo. Para a autora, o texto performativo diz respeito a uma tessitura que é indissociável da representação, que só existe na materialização da cena, sendo componente dela, e que se escreve a partir da cena, de maneira que só poderia ser compreendido neste contexto ${ }^{135}$.

Esta definição leva à questão da referencialidade, ou mesmo, da falta dela. Isto porque se um texto performativo só se legitima quando criado na cena, não se pode lançar mão de algo que esteja fora dela, ou seja, de uma ideia preestabelecida por outra voz. Isto pode ser constatado quando a autora faz a diferenciação entre texto espetacular e texto performativo, sendo ambos considerados textos da cena. Pois, tratados como dramaturgia, tanto um quanto outro pode ser considerado "ato de tecer", ou mesmo, uma tessitura entre objeto/jogo/encenação em que cada elemento é indissociável do outro e converge para o mesmo fim. Mesmo os textos dramáticos redigidos previamente, com finalidade moral,

${ }^{135}$ Noções apresentadas por J. Féral na disciplina oferecida pelo Dep. de Artes Cênicas da USP, no primeiro semestre de 2009. 
autônomos à cena e para os quais a cena deve convergir todos os seus esforços para ser "um simples local para espacialização e visualização dos enunciadores textuais" (Barthes) seriam considerados textos espetaculares. Contudo, o texto performativo se caracteriza por ser indissociável da ação, por existir em função do que se apresenta em cena, de modo que seria a própria materialidade da cena quem o redige. Nas palavras de Schechner, assim como a performance, ele é reflexivo.

O interessante é que o texto performativo, apesar de ser composto por buracos, explodido, partilhado, estilhaçado, isto não impede que haja uma narrativa implícita no seu jeito de apresentação. Pois ele pode, "evocar múltiplos discursos, que, no entanto, permanecem lineares e portadores de um discurso principal" e como tal se presta a uma narração, a um sentido navegável. Outra acepção deste tipo de texto performativo está ligada a encenações que fazem uso de textos "esburacados", normalmente heterogêneos, nos quais o sentido está ligado não à lógica de um discurso, mas à combinatória de diversos elementos. Em ambos os casos, seja associado à narração ou desprovido de discurso, esses textos não descrevem algo que exista para além da realidade em que eles se atualizam.

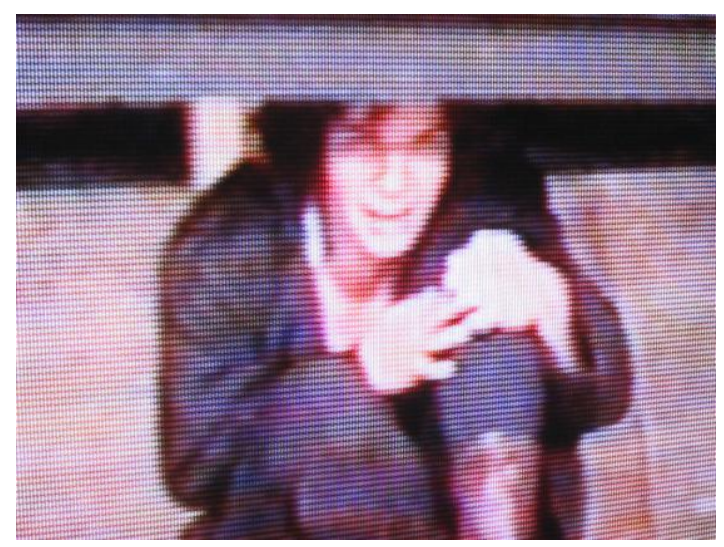

Figura 8 - Cena do espetáculo “Cuidado Frágil!” da Cia. de Teatro em Quadrinhos.

O espetáculo “Cuidado Frágil!” foi criado a partir de ações que derivaram de perguntas, argumentos ou imagens advindas de um universo temático: crimes contra a humanidade. Todos os gestos, movimentos dos corpos, coreografias, até mesmo, garatujas e balbucios foram 
desenvolvidos diretamente na cena pelos atores, como respostas a diversas "perguntas" 136 aferidas pelas diretoras. Posteriormente, introduzimos no espetáculo fragmentos textuais diversos - contos, poesias, artigos de jornais, depoimento dos atores que foram tratados como fluxos de pensamento que permeavam a cena. Tais materiais serviram de contraponto à coreografia da encenação ${ }^{137}$, estabelecendo uma linguagem híbrida entre teatro e dança.

Mas o texto deste espetáculo pode ser considerado performativo? Os textos compilados para esta montagem eram uma comunicação verbal, prerredigidos, compostos por enunciadores textuais, e nesta medida poderiam ser considerados textos espetaculares apesar de não terem sido escrito para cena, foram levados à cena e utilizados como motor para construção de situações e criação de ações edificadas pelos atores. No entanto, não estavam postos para dizer da situação que se apresentava. Seus possíveis sentidos não eram percebidos como totalidade de forma que constituíssem um discurso, uma narrativa, pois não havia nenhuma ação para ser contada. Ao contrário, era o caráter de parcelamento dos discursos, que ora se apresentavam como ação, ora como gestos, ora como palavras que faziam com eles tivessem algum sentido na rede de sistema da cena.

Apresentamos a seguir, exemplo de texto retirado de artigo de jornal e o tratamento dado a ele:

(Não adianta. A humanidade conhece os crimes do Estado ianque e sabe que os terroristas estão na Casa Branca). Acnarb asac an oatse satsirorret so euq ebas e euqnai odatse od semirc so ecehnoc edadinamuh a atnaida oan

No tratamento dado ao trecho descrito - frase falada ao contrário - vê-se que não há um enunciado inteligível, disposto a comunicar um logos. Consequentemente, a fala da atriz não pretendia esclarecer ou responder a uma ideia, tampouco defender uma moral. Ao vociferar um conjunto de letras desconexas, que perderam seu referente no momento em que

\footnotetext{
${ }^{136}$ Este método utilizado na criação teve como fundamento os princípios do processo criativo de Pina Bausch.

${ }^{137}$ Optamos em utilizar o termo coreografia da encenação para manter a coerência em relação aos procedimentos utilizados para a encenação. E mais, o espetáculo, apesar de ter sido criando em cena pelos atores, foi montado como uma grande coreografia, pois as diretoras organizaram-no como um roteiro de movimentos. (Conjunto de movimentos/cenas/quadros dispostos em sequência).
} 
se inverteu a ordem das palavras, o que se via em cena era a intensidade dos gestos da atriz, sua postura diante do público, ao qual ela encarava numa atitude de enfrentamento. As palavras, aqui, tornaram-se gestos vocais que mobilizaram o corpo e serviram de suporte para uma relação direta entre atriz e público. Interessante notar que o texto tomado em seu sentido literal traz um posicionamento ideológico claro. No entanto, quando composto em seu contrário, perde completamente o sentido e, do mesmo jeito, o público não tem nenhum ponto de apoio que o faça articular um pensamento em direção ao que ele poderia se referir. A atriz, tampouco, se esforça em ir ao encontro de seu posicionamento moral. Apesar de servir de apoio para sua investida, ela trabalhou na materialidade da palavra, na sonoridade, no ritmo das sílabas que pareciam remeter a um dialeto africano. Arriscamos a que neste caso o referente se distorceu.

Além disto, a atriz não figura nenhum personagem, não utiliza nenhuma máscara. Sua vestimenta, composta por trajes escuros, pesados, como calça, jaqueta, coturno, etc. tornamse, por sua vez, significantes sobreposto à sua atitude. Pode-se neste caso tratá-la como uma imagem onde se concentra uma pluralidade de significantes. Enquanto a atriz retira sua roupa, peça por peça, ficando apenas com roupas íntimas, o espectador se vê absorvido pelo ritmo de sua ação, pela intensidade da sua voz, pela gestualidade que dança. Seu investimento em direção à plateia está mais próximo de uma relação real, de forma que seu corpo pode ser percebido como expressividade sem a intenção de representar um preexistente. A força que a atriz emplaca ao detonar suas palavras é o que estabelece um contato enérgico com a plateia, o que se aproxima da noção de presença e dos fluxos libidinais que seu corpo expressa. 0 espectador liga sua figura aos outros elementos que a compõem, ou seja, à ação que ela executando (tirar a roupa), ao cesto de lixo que ela carrega com uma criança-boneca suja de sangue, à sua corrida posterior e ao grunhido que solta no final de sua ação. Toda esta estrutura é o que faz com que o espectador projete uma possível personagem em situação. Entretanto, em seguida, esta figura se desmonta e não retorna mais à cena, e outra cena, que não pretende ser continuidade desta, começa a se desenrolar. O espectador, assim, estabelece uma relação com aquela figura naquele momento, mas em seguida todo este campo se desvanece e abre-se espaço para a constituição de outra realidade cênica. Pode-se dizer que no 
primeiro momento processou-se uma teatralidade e no instante em que a coisa se desvanece e outra coisa se apresenta ocorre uma performatividade da cena, a realidade se modifica, aquilo que aconteceu, aconteceu naquele momento, estabeleceu-se certa suspensão na cena, e outro universo começou a se apresentar.

Pode-se notar que este espetáculo produz um texto performativo que "só existe dentro e para a representação, a qual Ihe dá sentido, o sustenta e Ihe confere coerência" ${ }^{138}$. Isto porque só se pode compreender o texto que ali se mostra em relação ao conjunto dos elementos cênico dispostos em cena. Nem o gesto da atriz, nem o texto proferido podem compor uma significância se vistos separadamente, pois não há autonomia dos elementos, eles estão justapostos e cria no deslocamento de uma cena à outra, na sobreposição de um elemento a outro, uma rede de comunicação. De fato, considerando as definições de Féral, o que se pretende abordar neste módulo cênico, diz respeito a uma rede de comportamentos, mais do que a um princípio de comunicação.

\section{Ação e texto}

No caso do espetáculo "Na Pele de Josef K." ${ }^{139}$, da Cia. de Teatro em Quadrinhos, o texto do espetáculo é de autoria de Luis R Cabral, que narra a história da personagem que dá título ao conto e tem como referência o personagem de Kafka e seu universo. Este texto pode ser considerado como texto espetacular, pois, apesar de não haver sido escrito para cena, foi levado à cena e utilizado como roteiro para criação de ações e situações dinamizadas pelos atores. Destaca-se o texto como material para operação cênica, pois foi a partir dele que o espetáculo se edificou. No entanto, os procedimentos utilizados para a criação não previam uma atualização ele foi utilizado como mobilizador das ações dos atores.

\footnotetext{
${ }^{138}$ Féral, J. Teoria e Prática do Teatro: Além dos Limites. Curso oferecido no Dep. de Artes Cênicas CAC/ECA/ USP, 2009.

139 Este espetáculo narra a história do personagem K., homem de meia-idade, desempregado, que, por erros burocráticos foi tomado como morto. Em sua trajetória, o personagem busca compreender e resolver este mal entendido, para com isso poder ser readmitido em seu antigo emprego. Tratado deste modo, o espetáculo tem uma história bastante simples em termos dramatúrgicos, porém, o que promove certa complexidade narrativa à história é o fato de ela ser dividida em cinco pequenos contos que apresentam o ponto de vista de cada personagem que compõe a história.
} 
Sem tomar conhecimento do texto sobre o qual trabalhavam, e menos ainda, que criavam em função de um texto, os sujeitos apenas se colocavam em situações a partir de um roteiro proposto pela encenadora: as ações eram solicitadas uma a uma e de modo subseqüente, e cada ator deveria, a seu modo, executá-las:

- esperar;

- esperar uma notícia;

- no meio da espera, ter uma lembrança positiva do passado;

- atender ao telefone;

- reagir à notícia;

- escrever uma apresentação de si;

- prever o próprio futuro.

Vê-se o foco aqui direcionado à realização de ações, e não à constituição de um universo ficcional. Esperar é apenas uma ação de aguardar. Podemos esperar diversas coisas em diferentes situações. Como se espera, porque se espera, quando se espera, onde se espera, que definiriam a constituição de uma situação imaginada, um se, não estava em questão. E mesmo quando acionada uma nova instrução, ou seja, esperar uma notícia, a espera criada anteriormente não deveria ser apagada, deveria ao contrário ser integrada à nova situação, de maneira que a espera continuava ser a ação a ser realizada. Seguia-se então o roteiro: no meio da espera acontece alguma coisa, e então se atende ao telefone. $\mathrm{O}$ ato de atender ao telefone modifica a situação anterior: os atores sabem agora que estavam aguardando um telefonema. Mas a condução era explicita, isto é, este novo dado não deveria de modo algum modificar a ação de espera criada anteriormente. Atender ao telefone, agora, era uma nova ação, neste caso mais objetiva e que já constitui uma situação fictícia.

Atemo-nos, portanto ao fato de esperar: os atores executam uma ação e devem permanecer com a mesma construção edificada inicialmente. Isto porque nos parece que, se os atores direcionassem a espera para a próxima ação, isto é, atender ao telefone, sua ação primeira não deixaria em aberto as possibilidades iniciais de uma ação de espera em termos gerais. Ou seja, uma ação ainda em suspenso, que deixa o estado de esperar aberto a muitas possibilidades. Assim é que esperar um telefonema diminuiria a amplitude da ação de espera. 
Esta é uma primeira consideração que parece projetar um modo de edificação que permite ao ator constituir ações que permanecem em suspensão, nem que seja por certo espaço de tempo, mas que, no entanto, são apresentadas em cena e não deixam que tomemos o sentido primeiro das coisas: o fato de somente esperar deixa a atenção do espectador voltada para um ato em potência, o que mantém seus sentidos atentos. No que tange ao ator, parece que este movimento instaura certa performatividade, pois ele está em cena a ponto de fazer algo, de agir para que algo aconteça. Isto significa dizer que ele está em potência e ao mesmo tempo em ato e sabe-se que a qualquer momento poderá modificar a realidade daquela circuntância.

Esta forma de proceder derivou, também, na constituição de uma diversidade de situações e máscaras corporais que não estavam estabelecidas no texto. Mesmo os textos acidentalmente trazidos pelos atores, ou ainda, outras vozes narrativas, comentários, flashbacks, forwards e reverses foram aproveitados pela encenação e constituíram outra camada dramatúrgica.

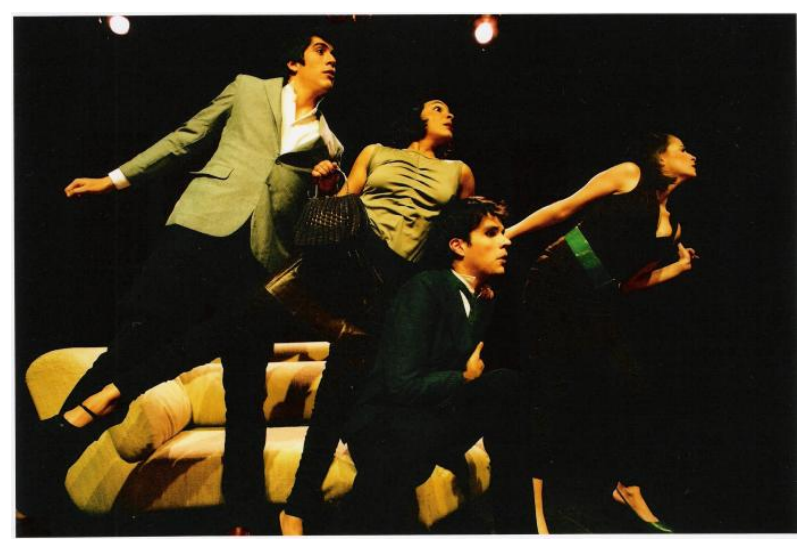

Figura 9 - "Na pele de Josef K." espetáculo em que os quatro atores representam e se revezam simultaneamente entre os diversos personagens do conto de Luiz R Cabral.

Era a situação e a condição em que o "personagem" Josef K. estava inserido que movia as ações dos atores. Cada um construiu uma máscara diferente para o mesmo personagem, a partir de sua corporeidade, imaginação e memória.

O texto serviu de suporte para a criação do espetáculo, que regulou a coesão da cena e permitiu uma noção de conjunto da obra teatral. No entanto, ele foi utilizado para ampliar e, por vezes, confundir os sentidos que poderiam ser apreendidos pela obra e não como um referente, o qual deveria ser atualizado: a cena não estava disposta a ilustrar uma situação, os 
criadores não pretendiam expressar uma ideia anterior, tampouco uma moral. O texto foi tratado como mais um elemento que só tinha função no conjunto que se mostrava.

Este jeito de proceder com o texto traz ainda um modo de atuação na qual o ator mantém como suporte para as suas ações as situações que criou a partir do roteiro. Pois, ao tomar conhecimento do texto, não foi solicitada uma adaptação de suas ações desenvolvidas a partir do roteiro àquilo que o conto propunha. Ao contrário, era justamente a disjunção entre e a figura e as situações cridas pelos atores e aquilo que o texto enunciava que criava fissuras na narrativa e explodia as possibilidades de sentidos que provinham daquele conjunto. $\mathrm{O}$ texto, nesta concepção, foi tratado como mais um "elemento da comunicação espetacular, de modo que se torna impossível declarar qual deles, cena ou texto, é anterior" ${ }^{140}$.

\section{Texto e expressão}

No espetáculo "Anônimos", concebido pela Cia. e escrito por um dos integrantes do grupo, Leonardo Moreira, o foco foi a montagem de um texto elaborado a partir dos interesses da companhia pautado sobre a questão da identidade no mundo contemporâneo. Apesar de haver sido elaborado em conformidade com as ideias do grupo, o texto não foi uma construção derivada da cena, a partir de jogos, atos performáticos ou improvisações dos atores. Foi escrito pelo dramaturgo e levado ao conhecimento dos outros integrantes do grupo que, como em um trabalho de mesa, analisavam, liam, pontuavam algumas questões e, assim, em um constante vai e vem, com interferência dos outros participantes, a versão ficou pronta para ser encenada.

Vale destacar que não percorremos, na elaboração do texto, uma narrativa linear, uma moral a ser defendida, tampouco unidade dramática. O texto se tornou uma espécie de síntese de ideias acerca de nossos questionamentos sobre identidade. Porém, ele trazia alguns princípios dramáticos: o espaço era definido (um hotel), a situação estava clara (o personagem K. era um detetive em busca da sua identidade, que se fazia duplicada em cena), os personagens eram funcionários ou hóspedes deste hotel que traziam consigo um universo próprio dotado de um drama particular (um ascensorista que havia assassinado um hóspede, uma diva decadente do cinema, um esportista islâmico acusado de terrorista, uma

\footnotetext{
${ }^{140}$ Pavis. op. cit.
} 
recepcionista misteriosa, uma cozinheira que efetuou uma chacina em uma escola infantil, etc.). Assim, diante do texto que trazia algumas definições, fomos para a cena na tentativa de criar sua composição espacial, caracterizar os personagens, experimentar seus diálogos.

Pode-se dizer, neste exemplo, que a Cia. trabalhou com uma abordagem mais tradicional em relação ao texto, isto é, procuramos dispor na cena as partes do roteiro, fixando traços de personagens indicados, ordenando os elementos verbais. Enfim, estabelecendo uma estrutura espacial discursiva na qual transporíamos o texto para a cena. Particularmente, tive alguma dificuldade em desenvolver tal procedimento por encontrar neste tipo de abordagem textual certa artificialidade em meu comportamento. Mas ocorreu um caso interessante na abordagem da personagem da cozinheira, personagem à qual me dediquei e em que todas as tentativas de realizá-la em cena foram frustradas. A personagem instigava-me pelo fato de revelar uma figura doce e materna como uma cozinheira - personagem tipo ${ }^{141}$ - ao mesmo tempo ativista de uma chacina de crianças em uma escola infantil.

Criamos, assim, deslocamentos no espaço, introduzimos objetos que auxiliaram para a sua caracterização, trabalhávamos com um texto estimulante que transitava entre a narração de uma matança que ela havia cometido e a descrição de uma receita culinária - esta forma textual exigia uma quebra no registro interpretativo, pois ao narrar seu crime, a personagem se envolvia dramaticamente com a situação, ao passo que, ao descrever a receita, ela se afastava de tal circunstância, mantendo uma relação profissional e distanciada de suas atitudes anteriores. Mas de nada adiantou: não havia ali nenhum traço expressivo, nenhuma força catalisadora. O texto estava moroso, sem dinâmica, a construção gestual não criava nenhuma potência expressiva enfim, o trabalho não chegava a nenhum resultado, no sentido de acionar uma comunicação.

Tentamos criar ações advindas das minhas memórias, procuramos referências em filmes, imagens, contos, mas nada adiantou. Até que pouco antes de estrear o espetáculo, a diretora solicitou uma modificação rítmica. Isto é, pediu que a atriz fizesse tudo muito rápido, a fala, os gestos, os deslocamentos, as expressões faciais. Eis que então tudo se modificou. 0

\footnotetext{
${ }^{141}$ No sentido de que o espectador não tem a menor dificuldade em identificar o tipo em questão de acordo com um traço psicológico, um meio social ou uma atividade. Pavis, op. cit. PP. 410
} 
ritmo criou um gestual expressivo, uma fala compreensível; a história ficou interessante para que o público acompanhasse atentamente os detalhes da chacina, entrecortada pela descrição da receita. A atriz aplicou ainda pequenas pausas que suspendiam sua respiração, seu olhar, sua movimentação, o que criou uma tensão em seu gestual. Parece que se instaurou a teatralidade no sentido que um universo imagético e enérgico se constituiu.

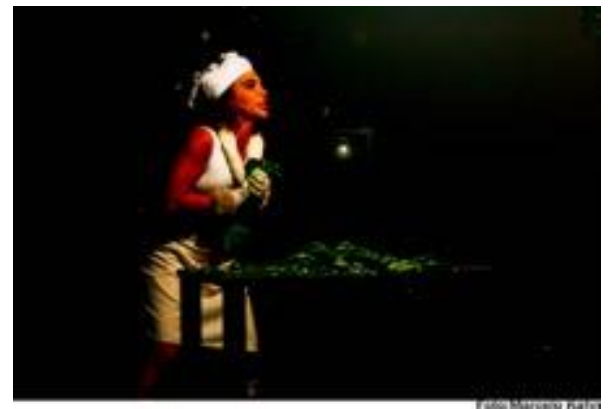

Figura 10 - Cena de Anônimos, personagem da cozinheira.

Gostaríamos de destacar com este exemplo a necessidade da criação de intensidade gerada pelo corpo do ator, para que se alcance uma comunicação com a plateia. Logo não seria necessário apenas um texto vibrante, um deslocamento diferenciado, objetos, figurinos, movimentações e deslocamentos no espaço para que o teatro alcançasse uma potência comunicativa. Parece necessário que o ator se aproprie do universo em que está inserido e, por meio do seu corpo, gere uma intensidade que magnetize todo o entorno, conferindo força e potencial imagético aos materiais e às circunstâncias à sua volta. A vibração que proveio da variação rítmica gerada pelo corpo da atriz parece ter sido o fator que acionou o campo da teatralidade.

\section{CONCLUSÃO: em cinco cliques: de salsicha a Platão!}

Se por muito tempo a arte teatral foi vista como descendente direto dos princípios apresentado por Aristóteles em "A Arte Poética", de forma que deveria realizar e cumprir, como uma espécie de programa, os princípios definidos pelo filósofo grego; se por mais que o teatro tenha lutado para ganhar autonomia e expressar-se enquanto fenômeno autônomo à literatura dramática; e se Aristóteles entenda a arte como imitação das ações humanas, há algo 
que ainda consideramos fundamental e não limitador para a arte teatral, isto é, a ação humana. Se existe algo de artificial na atuação naturalista, que corresponde, ao seu modo, a uma cena convergente aos princípios aristotélicos, isto se dá mais em função do uso de máscaras fixas, predeterminadas e imutáveis que correspondem à noção de sujeito como uno e indiviso, representado por um Eu, que pressupõe uma essência ${ }^{142}$. E não pelo fato de presenciarmos em cena ações humanas. Ao contrário, ação é condição humana, assim como o corpo em ação na cena é realidade teatral.

Assim é que, se as teorias contemporâneas ditas pós-estruturalistas substituíram a definição clássica de sujeito por "um complexo agenciamento de sentidos, uma grande teia de significados criados, mantidos e modificados pela linguagem" ${ }^{143}$, as pessoas que vemos em cena neste teatro não naturalista estão mais próximas da vida - a mesma vida que foi campo de exploração para a arte a qual Aristóteles se refere. Acredita-se com isso, que as teatralidades que percorremos nesta cena contemporânea não parecem querer negar a existência do sujeito em ação - o mesmo sujeito em ação que somos e presenciamos na vida, mas sim realizá-lo na cena com a mesma perspectiva em que ele é pensado na contemporaneidade. Isto quer dizer que, explorar seu corpo enquanto imagem, figura e indícios de algo que pode vir a ter sentido nas teias da memória, seria mostrá-lo em diferentes perspectivas, figurado, transfigurado e desfigurado, um ser que se cria e se reinventa a cada passo. Parece-nos que isto seria aproximar a linguagem da vida, ou seja, um ser que permanece aberto às possibilidades de ser, seja no contexto artístico, seja mesmo no contexto da vida.

\footnotetext{
142 A crise do sujeito, instaurada no último século, passou a integrar as reflexões das práticas artísticas contemporâneas. Se levarmos em consideração a perda da subjetividade instaurada no mundo das aparências, o caminho percorrido hoje, no chamado pós-modernismo, parece estar calcado na tentativa de resgatar a subjetividade perdida. O que se legitima nos tempos atuais, enquanto possibilidade de existência se fia na ausência da essência. Esta, então, foi substituída por um processo de subjetivação. O que se encontra como alternativa para o resgate da subjetividade é a possibilidade de sermos, a cada dia, outra coisa. Isto, em função da transitoriedade das coisas neste mundo que se apresenta fugaz e temporário. Não entraremos aqui nos embates filosóficos. Mas esta acepção de um sujeito transitório não poderia nos encaminhar a uma possibilidade de viver experiências descartáveis? Esta questão permanecerá em aberto. No que diz respeito à arte, talvez seja a arte da performance a proposta que mais se aproxima desta tentativa de resgate do sujeito. Ao dar ênfase à ordem da presença, ao corpo, aos desejos e pulsões, ela não estaria concedendo ao ser uma possibilidade de voz, de expressão?

${ }^{143}$ S. C. Mariani, Bethania. Sujeito e sentido: efeitos de linguagem
} 
Diante dos novos paradigmas que orientam nosso olhar sobre o sujeito, sobre a vida e sobre a linguagem, o personagem teatral, igualmente, não pode ser pensado como algo imutável e previsível. Decorre daí nossa insistência do corpo como imagem em ação, não ter como objetivo final a encarnação de uma entidade de traços psicológicos, que vive uma realidade autônoma reproduzida em cena. Antes disto, nesta concepção ele parece estar mais próximo das formas abstratas que o corpo pode produzir, mais livre e flexível para encarar os acontecimentos e, porque não, mais passional e sensível. E, ainda que em cena seja possível vislumbrar a presença de um personagem, este não é mais tratado como a ilusão de uma pessoa humana, a qual o ator deve esforçar-se ao máximo em imitar suas ações de modo que o espectador o perceba como realidade que existe em um universo ideal. Os atores parecem agora querer disponibilizar seu corpo para executar ações na realidade da cena, criar texturas e fazer coisas naquele tempo e espaço do evento. Se os atores que agem diante de nós em cena mantêm, em sua intimidade, a intenção de experimentar os processos de subjetivação desencadeados pela cena; se seus corpos estão disponíveis para vivenciar os riscos e perceber as condições de sua falibilidade; se em presença estão dispostos às experiências acionados pelo presente instante da cena, não estão procurando imitar outros nem tampouco imitar a si mesmos. Eles estão agindo conforme a realidade que eles próprios produzem. Uma atitude que pode ser expandida para a vida, assim como, uma atitude que deriva do seu próprio modo de agir na vida. Esta configuração da cena contemporânea parece, assim, demandar uma atitude convergente a um modo de ser, de modo que nossa ação em cena seja também uma ação de vida.

E mais, se o "drama significa literalmente algo feito" ${ }^{144}$, a cena atual parece interferir na flexão do verbo fazer. Isto é, se outrora ele era flexionado no particípio passado (feito), agora ele é flexionado no presente contínuo (sendo feito), ou mesmo utilizado no modo gerúndio (fazendo). Este modo verbal sugere ao teatro uma ação humana realizada continuamente, ou seja, não a reprodução de algo que aconteceu, mas um espaço onde algo está acontecendo. Assim, a perspectiva do teatro parece deslocar seu foco, ou seja, se antes a questão girava em

\footnotetext{
${ }^{144}$ Mc Leish, Kenneth, Aristóteles: A Poética de Aristóteles. Ed. Unesp, São Paulo 2000.
} 
torno do princípio da imitação, parece-nos que hoje o que está em questão é o verbo fazer, que pode ser somado, e também, refletido ao princípio da ação humana: ao fazermos, agimos. Algo que sugere uma experiência e um fazer, ligados intimamente aos aspectos do real o que, consequentemente, atrai o teatro cada vez mais para este plano, distanciando-o de uma realidade ideal que deveria ser expressa em cena. Esta seria a primeira consideração.

A segunda consideração diz respeito à relação da teatralidade e da representação que tangencia a perspectiva de um corpo tratado como imagem. Ou seja, qualificar o corpo/sujeito como imagem seria pensá-lo como verdadeiras catapultas que acionam nossos processos imaginativos e estéticos. $E$, do mesmo modo que não estamos mais falando de simulacros, um corpo em teatralidade seria algo que infere uma representação que acontece no momento em que as imagens se mostrem diante de nós. E não como algo que representa, a priori, alguma coisa para nós. Ou, este corpo imagem pode ser compreendido como lentes que ampliam e distorcem as coisas, à medida que estão disponíveis ao processo de construção de teatralidades. E, assim, promovem uma representação que avança em direção a outros mundos que são gerados pelo investimento da subjetividade do espectador em relação ao que se vê e ao que se sente.

Nesta perspectiva a representação é, ela também, deslocada. Isto significa dizer que, se ela era proposta pelo artista, e estava intrinsecamente ligada ao objeto e ao ato criativo, a representação passa a ser uma ação que o espectador projeta sobre as coisas. ${ }^{145} \mathrm{~A}$ razão da presença desta imagem/corpo ali pode não ter uma finalidade objetiva. Ao contrário, podem ser apenas imagens de potencial expressivo, sem razão moral, conceitual ou causal. Isto faz com que a ênfase recaia mais sobre a subjetividade dos sujeitos que compartilham a experiência do ato teatral do que sobre a obra ou o objeto, o que outrora era apresentado

\footnotetext{
${ }^{145}$ E uma questão mantém-se aberta: este modo contemporâneo de fazer recair toda a carga da representação sobre o espectador, não nos conduz a uma relação com o teatro menos coletiva? Não seria um retorno a um modo individualista de conceber o mundo? Se o público mantiver apenas uma apreciação subjetiva sobre o objeto, isto não faz com que a arte teatral se torne uma experiência individual, perdendo assim, seu princípio de coletividade? Algo que o espectador diria assim: "Para mim, é isto." E o outro, "Ah, não, para mim é aquilo!" E com isso diríamos: "Não podemos participar da mesma experiência, afinal de contas cada um é cada um." Assim, uma contradição parece ocorrer, ou seja, se encontramos, cada vez mais, nos discursos artísticos uma preponderância da arte como ritual, em busca da comunhão, ao tomarmos aquela perspectiva apresentada acima, não estaríamos nos distanciado deste princípio?
} 
como, a priori, a representação de algo. Mas esta imagem que é corpo e que está em expressividade também não carrega consigo desejos? Afinal, o corpo que vive a cena age com desejo, é corpo humano em sua totalidade orgânica. Assim, vamos um pouco além e arriscamos: o objeto (corpo/imagem/sujeito) e o sujeito (espectador) fundam juntos, no momento do ato teatral, uma força que se expande em teatralidades e desencadeia o processo estético, no qual um depende do outro para se realizar.

Para além das esferas subjetivas processadas pelo e no corpo, tratar este corpo como imagem seria, ainda, abordá-lo como elemento que compõe a visualidade da cena, isto se o tomarmos em seus aspectos materiais. Pensa-se então em materialidade enquanto visualidade. Uma visualidade material, táctil, que estimula a imaginação e a irrupção de um mundo outro, uma visualidade que infere alteridade. Uma visualidade que propicia um voo à imaginação. De forma que, aquilo que se vê, isto é, a imagem, a materialidade, a plasticidade das coisas, quando se desdobram em teatralidades, tangenciando a ficção e acionando nossos processos especulativos, legitima buscar uma narrativa de superfície que se desenvolve de modo horizontal, por acumulação e anexação, uma narrativa de paisagens que possibilita construir uma dramaturgia de sensações, que por sua vez, se opõe à história totalizante.

Interessante notar que a partir deste universo físico, material e real é possível a construção de uma linguagem que está fora do discurso que fala ao logos. É possível referir-se a um discurso que é produzido pela superfície material onde o teatro pode ser visto como uma sequência inumerável de imagens que agem sobre os nossos sentidos. Isto é, podemos dizer que apreender o mundo por sua materialidade conduz a imaginação a se revelar como um espaço onde passeia o irrestrito. De maneira que o palco se torna um mundo de imagens, um mundo de imaginação, um espaço que busca a expressividade da própria imagem. A mesma expressividade invisível que emana do corpo, que se sente, que se toca, mas que não dita. Uma expressividade que não deseja revelar, mas catalisar uma realidade invisível, sensível. Uma imagem que se revela enquanto presença sem ficção. $E$ arrisco mais uma vez: um corpo/imagem age não só porque se movimenta em cena, mas porque nos movimenta.

Assim é que nesta cena contemporânea presenciamos uma simultaneidade de elementos que convergem para o mesmo fim, isto é, o acontecimento teatral. O que 
experimentamos seria a superposição de diversas linguagens que se estendem em uma dissonante escala de representação, que se dá por meio de associação de imagens que passeiam em nossa imaginação, como coisas que nos permitem perceber o mundo numa visão mais pluralista e multifacetada. Deste modo, a cena que enfatiza o aspecto visual, imagético e sensual como meio expressivo parece dar consistência à multiplicidade das coisas e do mundo, para possibilitar, na brevidade de uma cena que se consome, a representação das coisas em ato e em potencialidade. $\mathrm{O}$ que se vê então é a diversidade de métodos interpretativos, maneiras de pensar, estilos de expressão explorados por meio da confluência ou por meio do choque. Onde o que conta não é a busca de uma figura harmoniosa, e sim a procura de uma força centrífuga que pode se libertar em meio à pluralidade de linguagens que faz com que a cena exploda em polifonia.

A cena teatral contemporânea parece equalizar-se, assim, por meio de uma estrutura modular, combinatória, acumulativa que faz expelir elementos figurativos de múltiplos significados, sejam eles sensíveis, concretos ou impalpáveis. E nestes infinitos universos de possíveis, onde todas as possibilidades podem se realizar, nós capturamos a combinatória de experiências, de informações, de leituras. E assim, o personagem teatral e o ator se tornam seres da vida, onde "cada vida é uma enciclopédia, uma biblioteca, um inventário de objetos, uma amostragem de estilos, onde tudo é constantemente remexido e reordenado de todas as maneiras possíveis." ${ }^{146}$ E sob esta perspectiva é válido destacar a diversidade de cada ator/corpo, a mesma diversidade que o singulariza, em que sua subjetividade imprime a multiplicidade de seu potencial que não se limita a ser um conhecido eu individual, mas de se deixar explorar para entrar em outros semelhantes a ele, para fazer falar o que não é palavra, para deixar-se ser o que ele é não se sabendo. Procurando ainda vasculhar sua intimidade sem, no entanto, deixar-se, mas sim permitir-se ser múltiplo, não outro um, mas ele sem ele. Uma identidade que se expressa por sua natureza móvel, plural, múltipla, sem jamais esquecer que "tudo aquilo que acontece com alguém, acontece agora, precisamente agora" ${ }^{147}$. Em que o corpo do ator em cena pode ser apreciado como imagem expressiva em ação sugestiva.

\footnotetext{
${ }^{146}$ CALVINO, Ítalo. Seis propostas para o próximo milênio. São Paulo: Companhia da Letras, 2008.

${ }^{147}$ Borges, J. Luis, O Aleph. Trad. Flávio José Cardoso. São Paulo: Globo, 1997
} 
Nesta conjuntura, o ator parece estar em busca da criação de uma figura e não de um personagem. Uma figura que se torna identidade móvel e cambiante, que não se fixa e não adere à linha, mas que cria espaços móveis que performatizam a teatralidade e que se deixa navegar por uma paisagem que o permite ser salsicha e/ou Platão.

\section{REFERÊNCIAS}

ABIRACHED, R. La crise du personnage dans lê théâtre moderne.Paris: Gallimard, 1994.

ABRAMOVIC, Marina. Générer une force. Alternatives théâtrales, Bruxeles: 2005.

AGAMBEN, G. Profanações, São Paulo: Boitempo, 2007.

ARAÚJO, Inês L. Foucault e a crítica do sujeito. Curitiba: Ed. Da UFPR, 2001.

ARISTÓTELES. Poética. Trad. Eudoro de Souza. São Paulo: Abril.

ARTAUD, A. O teatro e seu duplo. São Paulo: Martins Fontes, 1999.

ASLAN, O. O Ator no Século XX. São Paulo: Perspectiva, 2005.

AZEVEDO, S. O Papel do Corpo no Corpo do Ator. São Paulo: Perspectiva, 2004.

BACHELARD, Gastón. O ar e os sonhos. São Paulo: Martins Fontes, 1990.

BARBA, Eugenio e SAVARESE, Nicola. A arte secreta do ator. Trad. Luís Otávio Burnier. Campinas: EdUnicamp/Hucitec, 1995.

BARTHES, R. História do olho. São Paulo: Cosac Naify, 2003.

BELLONI, A. O Corpo e as coisas: a dissolução da fronteira entre o vivo e o não-vivo no contexto do teatro contemporâneo. In. Sala Preta - Revista de artes cênicas/USP, São Paulo: 2008.

BERNARD, Michel. Les corps. Paris: Éditions du seuil, 1995.

BERNARD, Viollete. TG Stan, um colectif posdramatique? In. Revue des estudes théâtrales, Registrs/8. Paris: Sorbonne Nouvelle, 2003.

BERNSTEIN, Ana. A casa com vista para o mar de Marina Abramovic. In. Sala Preta - Revista de artes cênicas, n.3, 2003.

. Marina Abramovic: do corpo do artista ao corpo do público. In. Vozes femininas, Rio de Janeiro: 7 Letras/ Casa Rui Barbosa, 2003. 
BERTHOLD, M. História mundial do teatro. São Paulo: Perspectiva, 2000.

BONFITTO, M. O Ator Compositor. São Paulo: Perspectiva, 2002.

. Do texto ao contexto. In. Humanidades. Brasília: Universidade de Brasília, 2006. . Sentido intenção e incorporação: primeiras reflexões sobre diferentes práticas interculturais no trabalho do ator. Sala Preta - Revista de Artes cênicas/USP. São Paulo: n. 5, 2005.

BORGES, J. Luis, O Aleph. Trad. Flávio José Cardoso. São Paulo: Globo, 1997

BORNHEIM, Gerd. O sentido e a máscara, São Paulo: Ed. Perspectiva, 2007

BRANDÃO, Helena H. N. Introdução à análise do discurso. Campinas: EdUnicamp, 1991.

BURNIER, Luis Otávio. A arte de ator: da técnica à representação. Campinas: EdUnicamp, 2001.

BÜRGUER, Peter. Teoria da vanguarda. São Paulo: Cosac Naify, 2008.

CALVINO, Ítalo. Seis propostas para o próximo milênio. São Paulo: Companhia da Letras, 2008.

CARLSON, M. Teoria do teatro: estudo histórico dos gregos até a atualidade. São Paulo : Unesp, 1997.

. Perspective on Performance: Germany and America. In. the transformative power of performance: A new aesthetics, Érika Fischer-Lichte, New York \& Londres: Routledge, 2008. . The resitance to theatricality. Substance : Theatricality, Vol. 31, 2002.

CHAUI, Marilena. Introdução a história da filosofia. São Paulo: Cia. das Letras, 2007.

CHECKOV, M. Para O Ator. São Paulo: Martins Fontes, 1996.

COHEN, Renato. Performance como linguagem. São Paulo: Perspectiva, 1989. . Work in progress na cena contemporânea. São Paulo: Perspectiva, 1998. e GUINSBURG, J. Do Teatro à Performance: Aspectos da Significação da Cena. In. Armando Sérgio da Silva (org.), Diálogos Sobre o Teatro, São Paulo: Edusp, 1992.

CORACINI, Maria José (org.). Identidade e discurso: (des)construindo subjetividades. Chapecó/Campinas: Argos/Ed. da Unicamp, 2003.

COUTINHO, J. Marco Antônio. Metáfora e metonímia; Condensação e deslocamento. In. Fundamentos da Psicanálise de Freud e Lacan: as bases conceituais. Rio de Janeiro, Zahar, 2002. 
. "O Imaginário", "O Simbólico" e "O Real" In. Lacan o grande Freudiano, Rio de Janeiro: Zahar, 2002.

DANTO, Arthur. Obras de arte e meras coisas reais. In. A transfiguração do lugar-comum; uma filosofia da arte. São Paulo: Cosac Naify, 2006.

DELEUZE, Gilles. Lógica do Sentido. Trad. Luís Roberto salinas Fortes. São Paulo: Perspectiva, 2000.

DELEUZE, Gilles e GUATTARI, Félix. Como criar para si um corpo sem órgãos. In. Mil platôs. Capitalismo e esquizofrenia. Vol. 3. São Paulo: Editora 34, 1999, P 9-29.

. O corpo sem órgãos. In. O Anti-Édipo. Capitalismo e esquizofrenia. Lisboa, Assírio

\& Alvim, 1966.

DERRIDA, Jacques. O teatro da crueldade e o fechamento da representação. In. A escritura e a diferença. São Paulo: Perspectiva, 1971, p. 107-177.

DORT, Bernard. La représentation émancipée. Paris: Actes Sud, 1988, p. 171-184

ERULI, Brunella. Dire l'irreprésentable, représenter l'indicible. In PICON-VALLIN, Béatrice (org.) La scène et les images. Paris : CNRS, 2001, p. 297-319.

ÉTUDES THÉÂTRALES 26. L'acteur entre personnage et performance. Paris/Louvaln. Centre d'études théâtrales/Institut d'etudes théâtrales, 2003.

FERNANDES, S. T. Teatralidades Contemporâneas In. Texto e imagem: estudos de teatro, Org. M. Helena Werneck e Maria João Brilhante, Rio de Janeiro: 7 Letras, 2009. P. 9-27

e MEICHES Mauro. Sobre o trabalho do ator. São Paulo: Perspectiva/Edusp, 1988.

FERNANDES, S. T. e GUINSBURG, J. (org.) Linguagem e Vida Antonin Artaud. São Paulo: Perspectiva, 2004.

FERRACINI, R. A Arte de Não Interpretar como Poesia Corpórea do Ator. Campinas: Ed. Unicamp, 2003. . O corpo cotidiano e o corpo-subjétil: relações. Publicação Abrace, 2003.

FÉRAL, Josette. Performance et théâtralité: le sujet démystifié. In. Théâtralité, écriture et mise en scène. Québec: Hurtubise, 1985, P 125-139.

. Mise en scène et jeu de l'acteur. T.2. Québec: Jeu/Lansman, 1998. 
. Mise en scène et jeu de l'acteur. T.1. Québec: Jeu/Lansman, 2001.

. Pour une poétique de la performativité : le théâtre performatif. Texto da palestra proferida no Encontro Mundial das Artes Cênicas, São Paulo: 2008.

. Dresser um monument à l'éphémère: rencontre avec Ariane Mnouchkine. Paris: Éditions Théâtrales, 2001.

. Um corps dans l'espace: perception et projection. In HAMON-SIRÉJOLS, Christine e SURGERS, Anne. Théâtre: espace sonore, espace visual. Lyon: Presses Universitaires de Lyon, 2003, p.127-155.

. Teatro, teoria y prática: más allá de lás fronteras. Buenos Aires: Galerna, 2004.

. Você disse 'training' ? Tradução. FALEIRo J. R. In. BARBA, Eugênio. Le training de l'acteur. Arles/Paris: Actes Sudes, 2000.

FERRÉ, Sylvie. Jan Fabre et Marina Abramovic, la rencontre de deux initiés. Alternatives théâtrales 85-86, 2005.

FISCHER-LICHTE, Érika. Realité et ficcion dans le téâtre contemporain. In Registre 11/12, Paris: Presses Sorbonne Nouvelle, 2007.

FLASZEN L., GROTOWSKI, J. O Teatro Laboratório de Jerzy Grotowski 1959-1969. São Paulo: Perspectiva/SESC/ Pontedera, 2007.

FONSECA, Márcio A. Michel Foucault e a constituição do sujeito. São Paulo: EDUC, 2003.

FOUCAULT, Michel. A ordem do discurso. Trad. bras. L. F. de Almeida Sampaio. São Paulo: Loyola, 1996.

. O que é um autor? Lisboa: Vega, 2006.

GALIZIA, L. R. Os Processos criativos de Robert Wilson. São Paulo: Perspectiva, 2004.

GOLDEBERG, Roselle. La Performance: du futurisme à nos jours. Paris: Thames \& Hudson, 2001.

GREINER, C. A Diáspora do corpo em crise: do teatro japonês aos novos processos de comunicação do ator brasileiro. In. Sala Preta - Revista de artes cênicas. São Paulo: n. 2, 2002. . O corpo. São Paulo: Annablume, 2005.

GROTOWSKI, J. Em Busca do Teatro Pobre. Rio de Janeiro: Civilização Brasileira, 1992.

GUÉNOUN, Denis. Le théâtre est-il nécessaire? Marseille, Circé, 1996. 
. Le futur de drame. In. Revue des estudes théâtrales, Registrs/8. Paris:

Sorbonne Nouvelle, 2003.

GUINSBURG, J. Stanislavisk, Meyerhold e Cia., São Paulo Perspectiva, 2001.

. Da cena em cena. São Paulo: Perspectiva, 2001.

KODO, Louis. Blefe - O Gozo Pós-Moderno. São Paulo: Editora Zouk, 2007.

LEHMANN, Hans-Thies. O teatro pós-dramático. São Paulo: Cosac\&Naify, 2007.

. Teatro pós-dramático e teatro político. In Sala Preta - Revista de Artes Cênicas/USP

3, 2003.

. Le risque, le tragique, le poison. Alternatives théâtrales 85-86, 2005, P. 71-73

LIMA, Luiz Costa. O controle do imaginário e a afirmação do romance. São Paulo: Companhia das Letras, 2009.

LIMA, Tatiana, Motta. Conter o incontível: apontamento sobre os conceitos de 'estrutura' $e$ 'espontaneidade' em Grotowski. In. Sala Preta - Revista de Artes Cênicas/USP N. 5, 2005.

LOPES, Elisabeth Silva. A performance da memória. Sala Preta - Revista de Artes Cênicas da USP, N. 10, 2010.

- Treinamento: a face e o dorso. Artigo a ser publicado na Revista O

Percevejo (UNIRIO), 2010

. A Blasfêmia, o prazer, o incorreto. Sala Preta - Revista de Artes Cênicas

da USP, N. 5, 2005.

. Ainda é tempo de bufões. Tese de doutorado. Universidade de São

Paulo, departamento de artes cênicas, orientação Jacó Guinsburg, 2001.

LYOTARD, Jean-François. La dent, la paume. In. Des dispositifs pulsionnels. Paris: Galilée, 1994, p. 91-98.

. O Pós-Moderno Explicado às Crianças. Lisboa: Dom Quixote, 1986.

MC LEISH, Kenneth, Aristóteles: A Poética de Aristóteles. São Paulo: Unesp, 2000.

MOREIRA, Wagner wey (org.) Século XXI: A era do corpo ativo. Campinas: Papirus, 2006.

O'REILLY, Sally. The body in contemporary art. Londres: Thames \& Hudson, 2009. 
OIDA, Y. O Ator Invisível. Colaboração de Lorna Marshal. Trad. Marcelo Gomes. São Paulo: Beca, 2001.

. Um Ator Errante. Colaboração de Lorna Marshal. Trad. Marcelo Gomes. São Paulo: Beca Produções Culturais, 1999

ORTEGA Y GASSET, José. A desumanização da Arte. São Paulo: Cortez, 2008.

PACHECO, Olandina de A. Sujeito e singularidade: ensaio sobre a construção da diferença. Rio de Janeiro, Jorge Zahar Ed., 1996.

PAVIS, Patrice. Dicionário de teatro. Trad. J. Guinsburg e Maria Lúcia Pereira. São Paulo: Perspectiva, 1999.

. A análise dos espetáculos. São Paulo: Perspectiva, 2003.

. La théâtralité en Avignon. In Vers une théorie de la pratique théâtrale. Paris:

Presses Universitaires du Septentrión, 2000, P. 317-337.

. O Teatro no cruzamento das culturas. São Paulo: Perspectiva, 2008.

. La Mise en scène contemporaine: origines, tendances, perspectives. Paris: Armand

Colin, 2007.

PAZ, Octavio. El arco y la lira. México: Fondo de Cultura Económica, 2003.

PELBART, Peter Pál. Esquizocenia. In Vida capital. Ensaios de biopolítica. São Paulo: Iluminuras, 2003, p. $145-150$.

. Ueinzz - Viagem a Babel. In A vertigem por um fio. São Paulo: 2000, P.99-108.

PICON-VALLIN, Béatrice (org.) Les écrans sur la scène. Paris: L’Age D’Homme, 1998, P. 171-205.

. “Hybridation spatiale, registres de présence, In PICON-VALLIN, Béatrice (org.) Les écrans sur la scène. Paris: L'Age D'Homme, 1998, P. 9-35.

. La mise en scene: vision et images. In PICON-VALLIN, Béatrice (org.) La scène et

les images. Paris: CNRS, 2001, p. 11-31

QUILICI, Cassiano. Antonin Artaud: o ator e física dos afetos. In. Sala Preta - Revista de artes cênicas/USP. São Paulo: n. 2, 2002.

. Teatros do silêncio. In. Sala Preta - Revista de artes cênicas/USP. São Paulo: n. 5,

2005. 
RAMOS, Luiz F. A pedra de toque. In. Humanidades, edição especial, Brasília: Universidade de Brasília, N. 52, 2006.

- Por uma teoria contemporânea do espetáculo: mimesis e desempenho espetacular. Texto e imagem: estudos de teatro, Org. M. Helena Werneck e Maria João Brilhante, Rio de Janeiro: 7 Letras, 2009. P. 89-103

REINELT, Janelle. The politcs of discourse: performativity meets theatricality. University of Wisconsin. Substance, vol. 31. PP 201-215.

RIPPELINO, A. M. Maiakóvski e o Teatro de Vanguarda. São Paulo: Perspectiva, 1971.

ROCHA, Tereza O corpo na Cena de Pina Bausch In. Lições de Dança 2. Rio de Janeiro: UniverCidade, 2000.

ROMANO, Lúcia. O Teatro do Corpo Manifesto: Teatro Físico. São Paulo: Perspectiva, FAPESP, 2005.

ROSENFELD, Anatol. Texto/Contexto. São Paulo: Perspectiva, 1969

ROUBINE, J-Jaques. A linguagem da encenação teatral. Rio de Janeiro: Jorge Zahar, 1998;

. A Arte do Ator. Rio de Janeiro, Jorge Zahar, 2002.

RYNGAERT, J-Pierre. Ler o teatro contemporâneo. São Paulo: Martins Fontes, 1998.

. Introdução à análise do Teatro. São Paulo: Martins Fontes, 1995.

e SERMON Julie. Le Personnage théâtral contemporain : décomposition, recomposition. Paris, Théâtrales, 2006.

SANTAELLA, L. Corpo e comunicação: sintoma de cultura. São Paulo: Paulos, 2004.

SARRAZAC, Jean-Pierre. L'invention de la théâtralité e la leçon des maîtres. In. Critique du théâtre. De l'utopie au désenchantement. Paris : Circé, 2000, P. 53-71 e 113-139.

. Travail Théâtral: une revue de théâtre à la époque de la fragmentation.

In. Revue des estudes théâtrales, Registres/8. Paris: Sorbonne Nouvelle, 2003.

. La reprise(réponse au postdramatique). In. Études théâtrales: la

réinvention du drame, Registres 38/39. Paris: Sorbonne Nouvelle2007.

SILVA, Armando, Sérgio. (org.) J. Guinsburg: Diálogos sobre teatro. São Paulo: EDUSP, 2002.

STANISLAVSKI, C. A construção da personagem. Rio de Janeiro: Civilização Brasileira, 1976.

. A Preparação do ator. Rio de Janeiro: Civilização Brasileira, 1968. 
SCHECNER, R. A emoção que se quer despertar não é a do ator, mas a do espectador In. Féral, J. Mise en scène et Jeu de l'acteur Montreal, Carnières, 2001.

. Performativity In. Performance Studies: an Introduction. New York \& Londres: Routledge, 2006.

What is performance? In. Performance Studies: an Introduction. New York \& Londres: Routledge, 2006.

SZONDI, Peter. Teoria do drama moderno (1880-1950). Trad. Luís Sérgio Repa. São Paulo: Cosac \& Naify Edições, 2001.

TREILHOU-BALAUDÉ, C. La scène et les images. In. Revue des estudes théâtrales, Registrs/8. Paris: Sorbonne Nouvelle, 2003.

UBERSFELD, Anne. L'école du spectateur. Paris, Belin, 1996

VIRMAUX, Alain. Artaud e o teatro. São Paulo: Perspectiva, 1978.

WORTHEN, W. B. Drama, performance and performativity. Modern Language Association, 1998. ZUMTHOR, Paul. Performance, recepção e leitura. São Paulo: Cosac Naify, 2007. 